\title{
A little known and synonym ant-lions 2 . (Neuroptera: Myrmeleontidae)
}

\author{
LeVente Ábrahám $^{1}$ \& Matthieu Giacomino ${ }^{2}$
}

\author{
${ }^{1}$ Rippl-Rónai Museum H-7400 Kaposvár, P.O. Box 70, Hungary, e-mail: labraham@smmi.hu \\ ${ }^{2}$ F-53940 Saint Berthevin 30, rue du moulin aux moines, France, e-mail: giacomino.matthieu@ hotmail.fr
}

Ábrahám, L. \& Giacomino, M.: A little known and synonym ant-lions 2. (Neuroptera: Myrmeleontidae).

Abstract: The authors examined antlion types in several collections and, as a result, 44 new synonymous names were found and 8 new combinations were established. Label data of the type specimens, distribution and some taxonomical comments were published. Acanthaclisis aurora Klapálek, 1912 n. syn. of Phanoclisis longicollis (Rambur, 1842); Creoleon pallida Fraser, 1950 n. syn. of Nohoveus lepidus (Klug in Ehrenberg, 1834); Myrmeleon tschernovi Krivokhatsky, N. A., Shapoval \& A. P. Shapoval, 2014 n. syn. of Myrmeleon bore (Tjeder, 1941); Myrmeleon montanus Navás, 1914 n. syn. of Myrmeleon trivialis Gerstaecker, 1885; Cueta elongata Navás, 1914 n. syn. of Cueta divisa Navás, 1912; Cueta externa Navás, 1914 n. syn. of Cueta indefinita Navás, 1914; Cueta gracilis Navás, 1924 n. syn. of Cueta indefinita Navás, 1914; Cueta simplicior Navás, 1934 n. syn. of Cueta indefinita Navás, 1914; Cueta pilosa Navás, 1934 n. syn. of Cueta indefinita Navás, 1914; Nesoleon scalaris Navás, 1912 n. syn. of Cueta pallens (Klug in Ehrenberg, 1834). "Nesoleon lepidus Klug." is a wrong combination (BANKs 1913) and not extant species. Cueta dissimulata Navás, 1913 n. syn. of Cueta trivirgata (Gerstaecker, 1894); Dendroleon qiongana Yang, 2002 n. syn. of Gatzara caelestis (Krivokhatsky, 1997); Dendroleon angulineura C.-k. Yang, 1987 n. syn. of Gatzara jubilaea Navás, 1915; Myrmeleon contractus Walker, 1860 n. comb. of Layahima contracta (Walker, 1860); Layahima nebulosa Navás, 1912 n. syn. of Layahima contracta (Walker, 1860); Distoleon cubitalis (Navás, 1914) n. comb. of Banyutus cubitalis (Navás, 1914); Formicaleo feai Navás, 1915 n. syn. of Banyutus cubitalis (Navás, 1914); Cymatala pallora C.-k. Yang, 1986 n. comb. of Banyutus pallorus (C.-k. Yang, 1986) and n. syn. of Banyutus cubitalis (Navás, 1914); Creoleon maurus Navás, 1923 n. syn. of Creoleon lugdunensis (Villers, 1789); Creagris interrupta Navás, 1914 n. syn. of Creoleon mortifer (Walker, 1853); Creagris loanguana Navás, 1913 n. syn. of Creoleon mortifer (Walker, 1853); Creoleon nigritarsis Navás, 1921 n. syn. of Creoleon mortifer (Walker, 1853); Creagris venosus Navás, 1914 n. syn. of Creoleon mortifer (Walker, 1853); Neeles roscidus Navás, 1937 n. comb. of Distoleon roscidus (Navás, 1937) and n. syn. of Distoleon nefandus (Walker, 1853); Distoleon symphineurus C.-k. Yang, 1986 n. syn. of Distoleon solitarius (Hölzel, 1970); Macronemurus interruptus Kolbe, 1897 n. syn. of Distoleon sylphis (Gerstaecker, 1894); Formicaleo turbidus Navás, 1915 n. syn. of Distoleon sylphis (Gerstaecker, 1894); Formicaleo lambarenus Navás, 1921 n. syn. of Distoleon sylphis (Gerstaecker, 1894); Formicaleo gilsi Navás, 1933 n. syn. of Distoleon sylphis (Gerstaecker, 1894); Neeles muzanus Navás, 1922 n. comb. of Distoleon muzanus (Navás, 1922) and n. syn. of Distoleon sylphis (Gerstaecker, 1894); Feina languidus Navás, 1931 n. syn. of Distoleon tholloni (Navás, 1914); Neuroleon parvissimus Fraser, 1952 n. syn. of Geyria lepidula (Navás, 1912); Formicaleo dumontinus Navás, 1933 n. comb. of Macronemurus dumontinus (Navás, 1933) and n. syn. of Macronemurus appendiculatus (Latreille, 1807); Macronemurus schoutedeni Navás, 1930 n. syn. of Macronemurus loranthe Banks, 1911; Macronemurus jejunus Navás, 1912 n. syn. of Macronemurus melanthe Banks, 1911; Macronemurus ianthe Banks, 1911 n. syn. of Macronemurus perlatus (Gerstaecker, 1885); Macronemurus nuncius Navás, 1913 n. syn. of Macronemurus perlatus (Gerstaecker, 1885); Formicoleo fictus Navás, 1913 n. syn. of Macronemurus perlatus (Gerstaecker, 1885); Formicaleo neavinus Navás, 1913 n. comb. of Macronemurus neavinus (Navás, 1913) and n. syn. of Macronemurus perlatus (Gerstaecker, 1885); Macronemurus wittei Navás, 1932 n. syn. of Macronemurus perlatus (Gerstaecker, 1885); Neuroleon lukhtanovi Krivokhatsky, 1996 n. syn. of Neuroleon erato Hölzel, 1972; Neuroleon nubilus Navás, 1913 n. syn. of Neuroleon (Ganussa) tenellus (Klug in Ehrenberg, 1834); Tahulus sordidatus Navás, 1936 n. syn. of Pseudoformicaleo gracilis (Klug in Ehrenberg,

ISSN 1587-1908 (Print); ISSN 2062-9990 (Online) 
1834); Indoleon tacitus sinicus C.-k. Yang in C.-k. Yang \& X.-1. Wang, 2002 n. syn. of Indoleon tacitus (Walker, 1853); Myrmeleon lagopus Gerstaecker, 1894 n. comb. of Nedroledon lagopus (Gerstaecker, 1894), Nedroledon striatus Hölzel, 1972 n. syn. of Nedroledon lagopus (Gerstaecker, 1894); Paraglenurus lotzi Miller \& Stange, 1999 n. syn. of Paraglenurus pumilus Yang, 1997. 49 photographs of type specimens are presented.

Keywords: Taxonomy, valid species, new synonym, lectotype designation, Palearctic, Afrotropic, Indomalaya.

\section{Introduction}

LinNAEUS $(1758,1767)$ established the science of taxonomy and nomenclature was followed by later researchers. Later, Neuroptera specialists provided more and more detailed descriptions and compiled the first catalogues (RAMBUR 1842 and WALKER 1853). Despite the greatest efforts and good intentions of the researchers, repeated species descriptions also happened.

In 1853, WALKER ranked all antlion species in one genus: Myrmeleon, which made their identification complicated. Later, in 1866, HAGEN restored the earlier classification ranking the species into different genera and also provided important species revisions. His works were completed by MCLACHLAN (1868), who continued the specific and generic revision of species listed in WALKER (1853).

Even in the earlier monographs, under their generic name, authors used to list literature references, together with the taxonomical changes to let us follow the changing status of the species. This practice continues today and is becoming more and more accurate. Nowadays, in the faunistic papers, not only name changes (combinations, synonyms, etc.) but numerous biological information is published like habitat, distribution, behavior, ecology, etc.

In the early 20th century, the antlion research became more intensive and a high number of species were described from non-European continents. Most of these descriptions were provided by Navás. He was criticized by several contemporary authors and a high number of his species was synonymized by BANKS (1913) and EsBEN-PETERSEN (1920).

In the second half of the 20th century, comprehensive studies and monographs were published on the antlion fauna of various geographic areas based on thorough explorations that were done ever before. Good examples of these works are HöLzEL 1972, GHosh 1984, New 1985a,b,c, and AspöK et al. 1980. In addition, major worldwide generic revisions were published eg. Hölzel 1987, MANSELl 1985, StANGe 1976, etc.

In the 21st century, this trend continued. For the future, revisions of genera Myrmeleon, Distoleon, Neuroleon, etc. shall be focused. In addition, the revision of the antlion fauna of smaller or larger countries shall be continued, eg. KRIVOKHATSKY (2011).

The catalogue of Myrmeleontidae by STANGE (2004), is the most important subrecent work providing a new synthesis of research in antlion taxonomy.

Recently online databases and web catalogues become more and more important. Lacewing Digital Library (Oswald 2019), the antlion of South Africa (Mansell 2018), Fauna Europaea (Letardi et al. 2019, etc., makes research easier. 
We are facing another major synthesis, since significant progress has already been made in the information transmission and in the digitization of type specimens, especially in various museums like MRAC (Belgium), ZMHB (Berlin) and TAUBER et al. 2019 , etc. All of these require more accurate taxonomic and nomenclature information and make our research even more efficient.

The aim of this paper is to provide new information and synonymous names discovered in the study of the type specimens in terms of more useful local fauna surveying and the distribution of the species.

\section{Material and methods}

In the first part of this paper, the material and methods entry was already elaborated. In the current paper, the same methods are applied (GIACOMINO \& ÁbraHÁm 2018).

The examined type and other non-type specimens are from the following collections:

BMNH - Natural History Museum, London, England.

CAUB - China Agricultural University, Beijing, China.

EMAU - Ernst-Moritz-Arndt Universität, Zoologisches Institut and Museum, Greifswald, Germany.

MCSN - Museu Civico de Storia Naturale "Giacoma Doria", Genoa, Italy.

MNHP - Museum National d'Histoire Naturelle, Paris, France.

MRAC - Musée Royal de 1'Afrique Centrale, Tervuren, Belgium.

NHMW - Naturhistorisches Museum, Wien, Austria.

USMB - Upper Silesian Museum, Bytom, Poland.

OXUM - Hope Entomological Collections, University Museum, Oxford, England.

ZMHB - Museum für Naturkunde der Humboldt Universitat zu Berlin,

Bereich Zoologisches Museum, Berlin, Germany.

Abbreviations. - Chlist, Checklist; Comb, New combination; Com, Comment; Dist, Distribution; Hom, Homonym; Mon, Monograph; Morph, Morphology; Nom, Nomenclature; Odescr, Original description; Syn, Synonym. 


\section{Results and discussion}

\section{Family Myrmeleontidae \\ Subfamily Myrmeleontinae Latreille, 1802 \\ Tribe Acanthaclisini Navás, 1912}

\section{Phanoclisis longicollis (Rambur, 1842)}

Acanthaclisis longicollis Rambur, 1842: 381 (Odescr).

Syn. Acanthaclisis aurora Klapálek, 1912: 144 (Odescr), n. syn., (Fig. 1) (Figure (C) by Natural History Museum Vienna, NOaS Image Collection; published with permission).

Nora aurora (Klapálek, 1912) - Navás 1912a (Comb).

Phanoclisis aurora (Klapálek, 1912) - Banks 1913 (Comb), Aspöck \& Hölzel 1996 (Chlist), Aspöck et al. 2001 (Mon), Stange 2004 (Mon).

Type of Acanthaclisis aurora. Checked, preserved in NHMW.

LECTOTYPE (present designation): female "/ Lectotype / Acanthaclisis aurora / Klapálek, 1912 / design.: Ábrahám \& / Giacomino 2019 [red label] /".

Label information. "/ Typus [red label] // Egypten 1904 [printed] / Medinet- / Fayum / 12. VIII [with Klapálek's handwriting] / leg. Werner [vertically printed] [white label] // Acanthaclisis / aurora n. sp. [white label with Klapálek’s handwriting] // Acanthaclisis / longicollis / Rbr. [handwritten white label] /".

In KLAPÁLEK (1912) "Medinet-Fayum, Ägypten, 12. August 1904; 1 ふึ".

Type condition. Bad, left forewing and tip of the abdomen missing.

Comment. Nora Navás, 1912a is a junior homonym of Nora Niceville, 1893 (Lepidoptera), the objective replacement name is Phanoclisis Banks, 1913. KLAPÁLEK (1912) described the new species based on the different measurements, colourization and the unspotted wings compared to Phanoclisis longicollis. All those characters are very variable especially the spotted or unspotted wings (KRIVOKHATSKY 2005a). Only the major monographs (AsPöcK \& Hölzel 1996, AsPöcK et al. 2001, STANGe 2004) listed the occurrence of the species in Egypt. El-Hamouly \& FadL (2011) did not mention it in the Egyptian checklist. An unknown person already put a handwritten label to the type as Acanthaclisis longicollis previously but this information was not found in the litera-

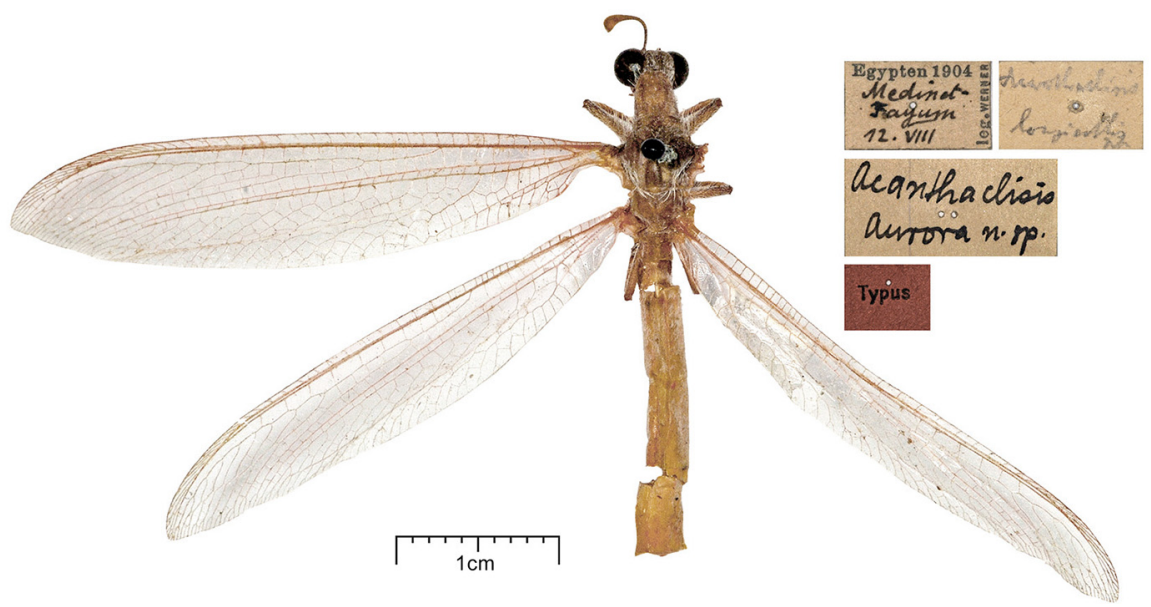

Fig. 1: Acanthaclisis aurora Klapálek, 1912 n. syn. of Phanoclisis longicollis (Rambur, 1842) 
ture (EsBen-Petersen 1920, AsPöck et al. 2001, Stange 2004). We confirm that Phanoclisis aurora Klapálek, 1912 is a new junior synonym of Phanoclisis longicollis (Rambur, 1842).

Distribution of Phanoclisis longicollis. It is a widespread species in the sub-Saharan and Saharan zones (Prost 1998) and in the Arabian Peninsula (ÁBrahÁm \& Harten 2014) but false data are known in South Africa (WALker 1853) and Indonesia (Stange 2004).

Tribe Myrmecaelurini Esben-Petersen, 1918

Nohoveus lepidus (Klug in Ehrenberg, 1834)

Nohoveus lepidus (Klug in Ehrenberg, 1834): 36 (Odescr).

Syn. Creoleon pallida Fraser, 1950: 124 (Odescr), n. syn., (Fig. 2).

Myrmecaelurus pallidus (Fraser, 1950) - Stange 2004 (Comb, Mon).

Type of Creoleon pallida. Checked, preserved in MNHP.

LECTOTYPE (present designation): male "/ Lectotype / Creoleon pallidus / Fraser, 1950 / design.: Ábrahám \& / Giacomino 2017 [red label] /"

Label information. "/ Type [red label] // Aïr . Agadez / 500 m. 3, VIII - 1947 / L. Chopard et / A. Villiers Rec. [blue label] // Museum Paris [white label with narrow black margins] // Creoleon [underlined] / pallida [underlined] $\hat{\delta} /$ Type [in capital letters and underlined] / det. F. C. Fraser [handwritten white label] /".

In Fraser (1950) "Agadez (Aïr) 500 m., 3-VIII to 13-IX-47 (L. C. and A. V.)".

Synonymy is marked as "/ Nohoveus lepidus / (Klug in Ehrenberg, 1834) / syn.: Ábrahám \& / Giacomino 2017 [white label in printed letters]/".

Type condition. Good, left antenna missing.

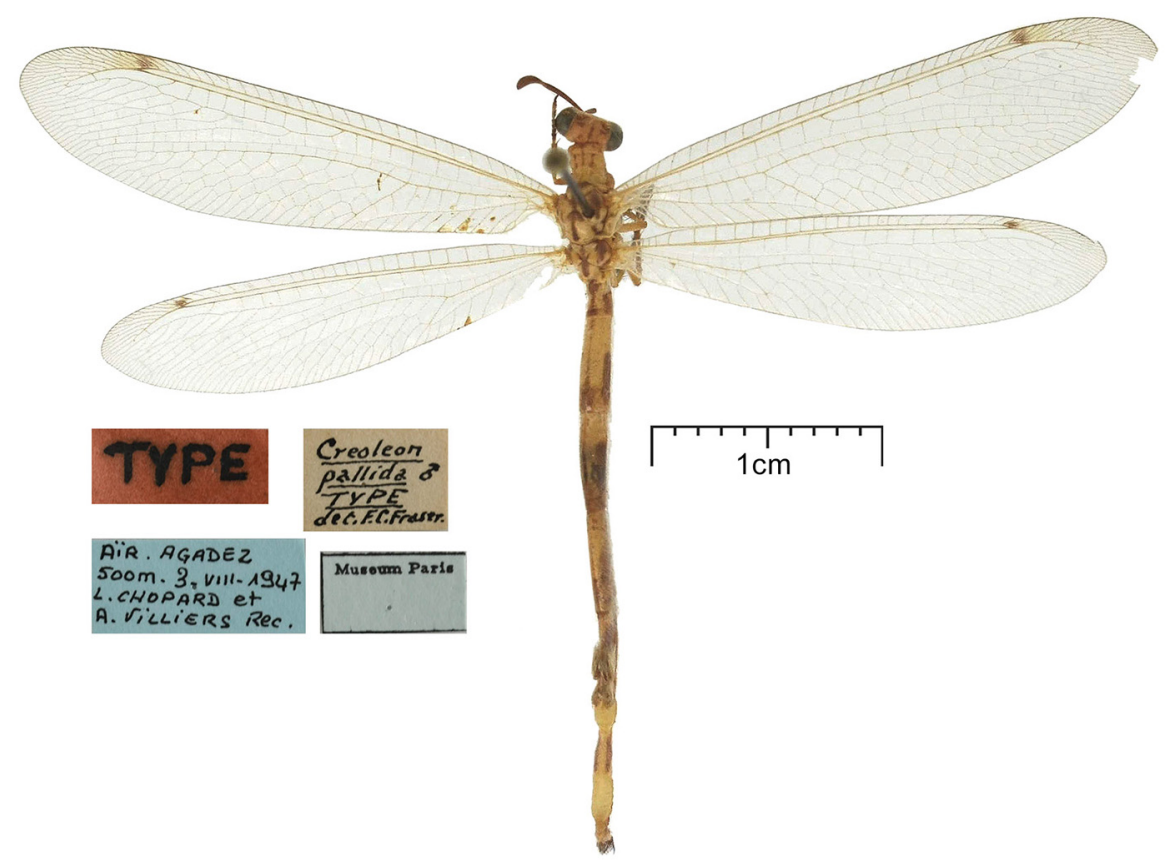

Fig. 2: Creoleon pallida Fraser, 1950 n. syn. of Nohoveus lepidus (Klug in Ehrenberg, 1834) 
Comment. Creoleon pallida Fraser, 1950 is a new junior synonym of Nohoveus lepidus (Klug in Ehrenberg, 1834). We agree with KRIVOKHATSKY (2005b) that synonymy of Myrmecaelurus A. Costa, 1855 with Nohoveus Navás, 1918 (StANGE 2004) is incorrect.

Distribution of Nohoveus lepidus. It is a widespread species in North Africa and in the Arabian Peninsula (StANGe 2004).

Tribe Myrmeleontini Latreille, 1802

Myrmeleon bore (Tjeder, 1941): 74 (Odescr).

Myrmeleon bore (Tjeder, 1941)

Syn. Myrmeleon tschernovi Krivokhatsky, N. A., Shapoval \& A. P. Shapoval, 2014: 173 (Odescr), n. syn., (Fig. 3).

Type of Myrmeleon tschernovi. Only non type specimens were checked in USMB.

Label information. "/ Kalinyingrad Ribacse, / ornitolog lovuska 2013 / A. Shapoval [white label in printed Russian letters] // N 132 K. k. / 27. 08. 2013 /14 [white label] // Myrmeleon tschernovi / Kriv. \& Shaps,. / V. Krivokhatsky [white label in printed letters] /". This male specimen was placed into the entomological collection of Rippl-Rónai Museum, Kaposvár.

In KrivoKhatsky et al. (2014) "Holotype: $\hat{\jmath}$, Kaliningrad Prov., Cu-ronian Spit, "Fringilla" Research Station, stationary trap for bird capturing, 12.VII.2012 (A.P. Shapoval)".

Specimen condition. Excellent.

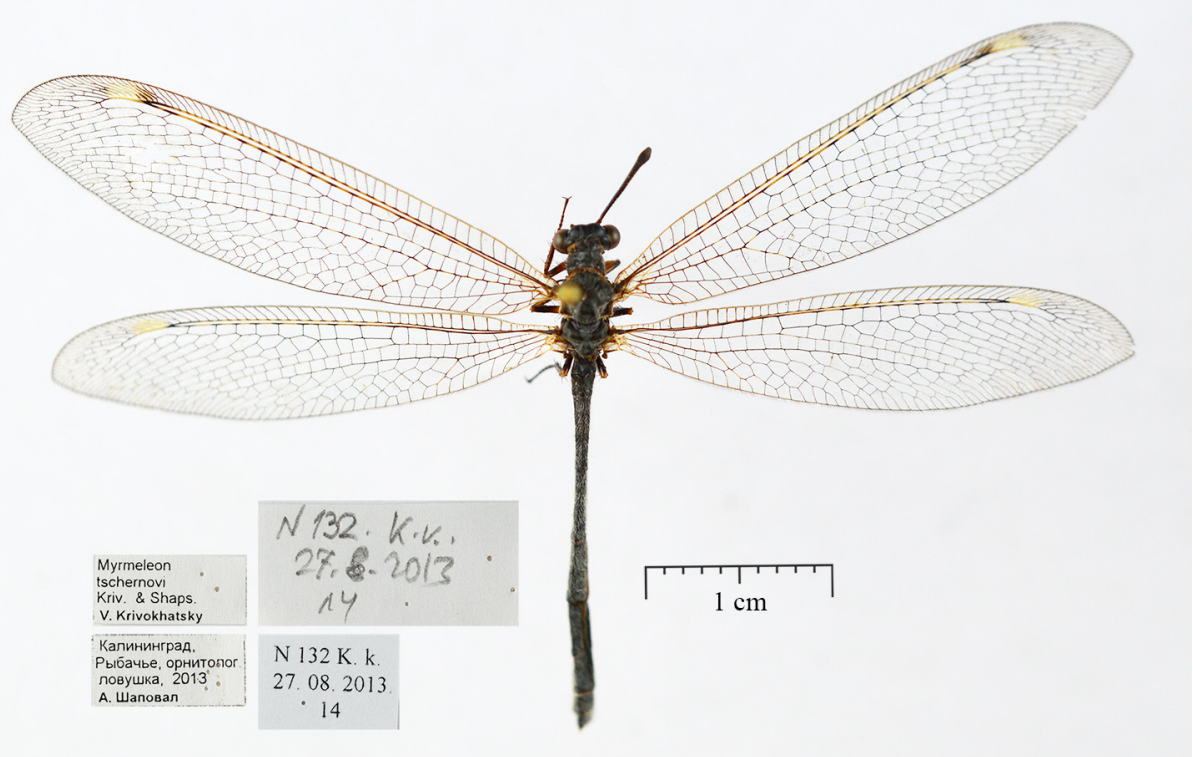

Fig. 3: Myrmeleon tschernovi Krivokhatsky, N. A., Shapoval \& A. P. Shapoval, 2014 n. syn. of Myrmeleon bore (Tjeder, 1941)

Comment. Myrmeleon tschernovi Krivokhatsky, N. A., Shapoval \& A. P. Shapoval, 2014 is a new junior synonym of Myrmeleon bore (Tjeder, 1941). Synonymy based on the accurate description (KRIVOKHATSKY et al. 2014) and non type examination. It is a common pit building species in the coastal area of the Baltic sea. 
Distribution of Myrmeleon bore. A widespread Palaeartic species from Europe to Japan (RöHRICHT 1998).

Myrmeleon trivialis Gerstaecker, 1885

Myrmeleon trivialis Gerstaecker, 1885: 23 (Odescr), Stange 2004 (Mon), Zhan et al. 2011 (Dist), Atkar et al. 2018 (Dist), Wang et al. 2018 (Mon), Yang, D. et al. 2018 (Chlist).

Syn. Myrmeleon montanus Navás, 1914d: 234 (Odescr), Ghosh \& Sen 1977 (Chlist), Ghosh 1984 (Mon), 1991

(Dist), 1997 (Dist), Stange 2004 (Mon), n. syn., (Fig. 4).

Type of Myrmeleon montanus: female checked, preserved in MNHP.

Label information. "/ Type [white label in capital red letters] // Museum Paris / Darjiling / Harmand 1890 [green label in printed letters] // Myrmeleon / montanus o Nav. / Navás S. J. det. [white label with Navás's handwriting] // Lectotype [red label in capital letters] // Myrmeleon / montanus / Navás, 1914 / Lectotype / J. Legrand det. 1992 [white label with Legrand's handwritting] /".

In Navás (1914d) "Himalaya: Darjeeling, Harmand 1890 (Mus. de Paris)".

Synonymy is marked as "/ Myrmeleon trivialis / Gerstaecker, 1885 / syn.: Ábrahám \& / Giacomino 2017 [white label in printed letters]/".

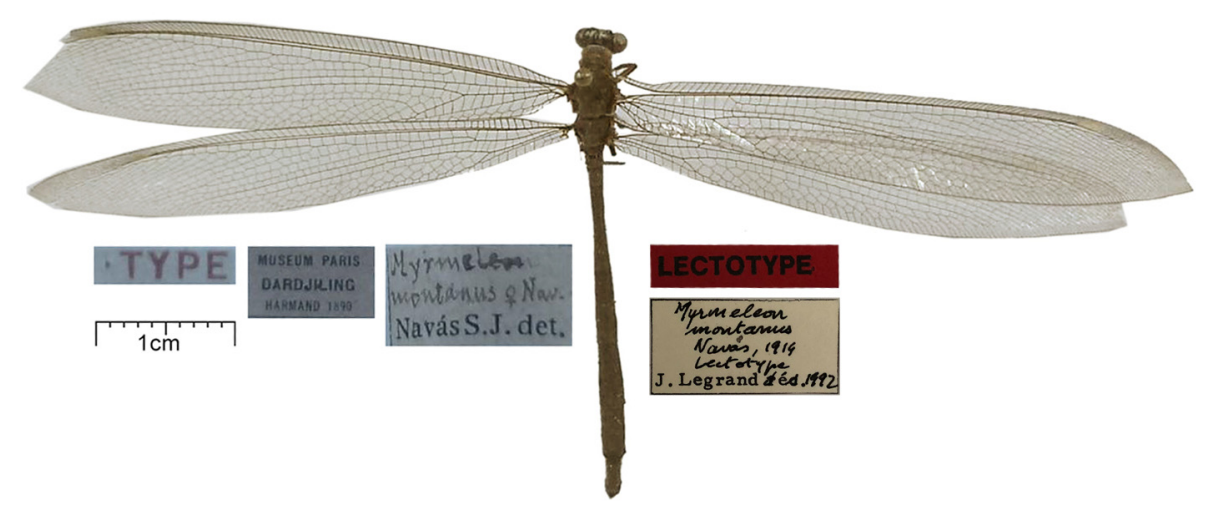

Fig. 4: Myrmeleon montanus Navás, 1914 n. syn. of Myrmeleon trivialis Gerstaecker, 1885

Type condition. Medium, antenna missing, tip of left forewing broken and base of right forewing damaged.

Comment. Myrmeleon montanus Navás, 1914 is a new junior synonym of Myrmeleon trivialis Gerstaecker, 1885

Distribution of Myrmeleon trivialis. A widespread species in the Oriental region (Pakistan, India, Nepal, Thailand, Vietnam and China).

Tribe Nesoleontini Markl, 1954

Cueta divisa (Navás, 1912)

Nesoleon divisus Navás, 1912c: 235 (Odescr), Banks 1913 (Syn).

Cueta divisa (Navás, 1912) - Oswald 2019 (Comb).

Syn. Cueta elongata Navás, 1914a: 17 (Odescr), Stange 2004 (Mon), n. syn., (Fig. 5). 
Type of Cueta elongata. Checked, preserved in MNHP.

LECTOTYPE (present designation): male "/ Lectotype / Cueta elongata / Navás, 1914 / design.: Ábrahám \& / Giacomino 2017 [red label] /".

Label information. "/ Museum Paris / Ch Alluaud / Et R. Jeannel [green label] // Afrique Orient. Anglaise / Tavéta / Alluaud \& Jeannel / Mars 1912 750m St 65 [white label in printed letters] // Cueta / elongata $\widehat{~}$ Nav. [with Navás's handwriting] / Navás S. J. det. [printed] [white label] /".

In NAvÁs (1914a) "Afrique Orientale Anglaise: Tavéta, alt. 750 m., st. nº 65, mars 1912 (Alluaud et Jeannel)".

Synonymy is marked as "/ Cueta divisa / Navás, 1912 / syn.: Ábrahám \& / Giacomino 2017 [white label in printed letters]/".

Type condition. Good, antenna missing.

Comment. It is conspecific with Myrmeleon variegatus Klug in Ehrenberg, 1834 which is a homonym and its name was replaced by HöLzel (1982) to Cueta klugi Hölzel, 1982. Cueta divisa Navás, 1912 is available for Myrmeleon variegatus Klug in Ehrenberg, 1834, consequently Cueta klugi Hölzel, 1982 is also synonym (OswaLD

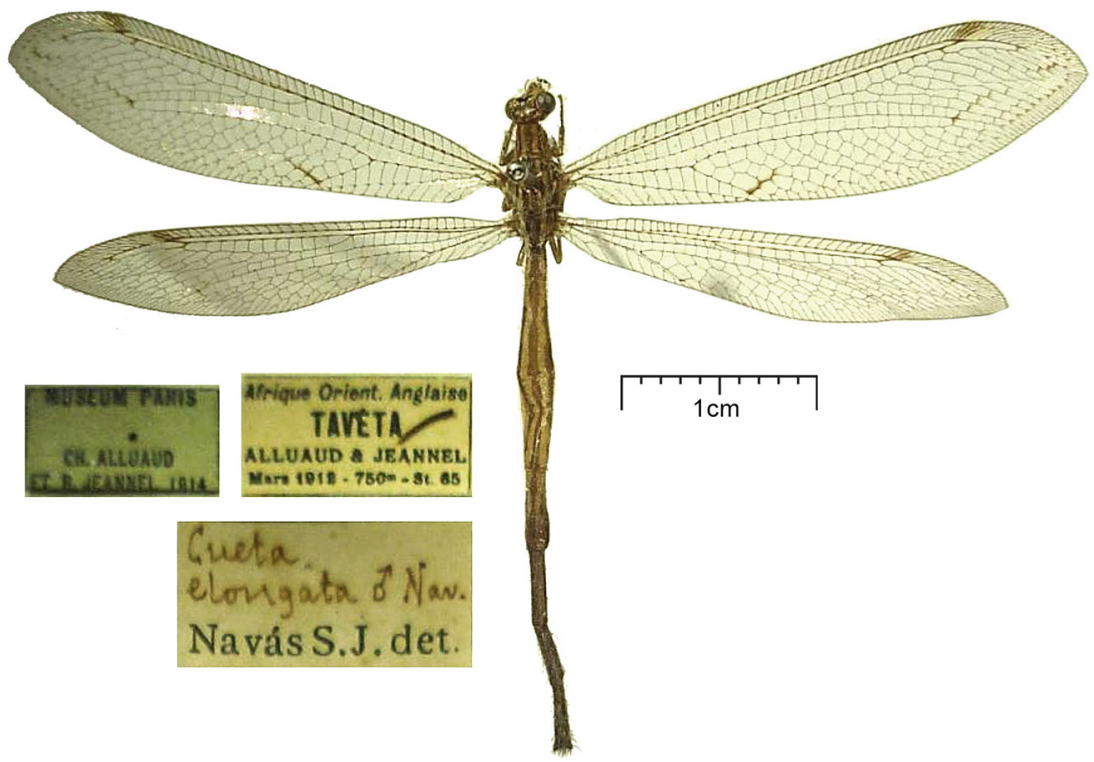

Fig. 5: Cueta elongata Navás, 1914 n. syn. of Cueta divisa Navás, 1912

2019). At first, Banks (1913) recognised the taxonomical status of Cueta divisa Navás, 1912 and synonymed to Myrmeleon variegatus Klug in Ehrenberg, 1834 but he did not consider that Myrmeleon variegatus Klug in Ehrenberg, 1834 was a homonym. Cueta elongata Navás, 1914a is a new junior synonym of Cueta divisa Navás, 1912.

Distribution of Cueta divisa. Data are known from the Saharan zone: Cape Verde Islands, Senegal, Sudan, Kenya, Somalia, Saudi Arabia, Oman, Yemen (as Cueta klugi) (AsPöcK et al. 2001) as weel as in Ethiopia (BANKs 1911), Tanzania (WeEle 1910), Chad (Navás 1912d). Its occurring in Madagascar (as Cueta klugi) (WeEle 1909, Penny 2004, STANGE 2004) needs to be reaffirmed. 
Cueta indefinita Navás, 1914

Cueta indefinita Navás, 1914b: 103 (Odescr), Penny 2004 (Chlist), Stange 2004 (Mon), Ábrahám \& Dobosz 2011 (Dist, Com), (Fig. 6).

Syn. Cueta externa Navás, 1914b: 104 (Odescr), Navás 1933a (Morph, Dist), 1934b (Morph, Dist), Handschin 1963 (Dist), Whittington 2002 (Dist), Penny 2004 (Chlist), Stange 2004 (Mon), n. syn., (Fig. 7).

Syn. Cueta gracilis Navás, 1924: 104 (Odescr), Penny 2004 (Chlist), Stange 2004 (Mon), Ábrahám \& Dobosz 2011 (Com), n. syn., (Fig. 8).

Syn. Cueta simplicior Navás, 1934a: 51 (Odescr), Penny 2004 (Chlist), Stange 2004 (Mon), Ábrahám \& Dobosz 2011 (Com), n. syn., (Fig. 9).

Syn. Cueta pilosa Navás, 1934a: 52 (Odescr), Penny 2004 (Chlist), Stange 2004 (Mon), n. syn., (Fig. 10).

Type of Cueta indefinita. Checked, preserved in MNHP.

LECTOTYPE (present designation): female "/ Lectotype / Cueta indefinita / Navás, 1914 / design.: Ábrahám \& / Giacomino 2017 [red label] /".

Label information. "/ Type [white label in capital red letters] // Museum Paris / Madagascar / Rég. de Sakarami / Maurice de Rothschild / 1905 [blue label] // Cueta / indefinita $q$ Nav. [with Navás's handwriting] / Navás S.J. det. [printed] [blue label] // Holotype [red label in capital printed letters] // Cueta indefinita / Navás, 1914 / Holotype / J. Legrand dét, 1992 [white label] /".

In NAvÁs (1914b) "Madagascar. Rég. de Sakarmi, Maurice de Rothschild." Type condition. Poor, left antenna missing, fore and hindwings damaged.

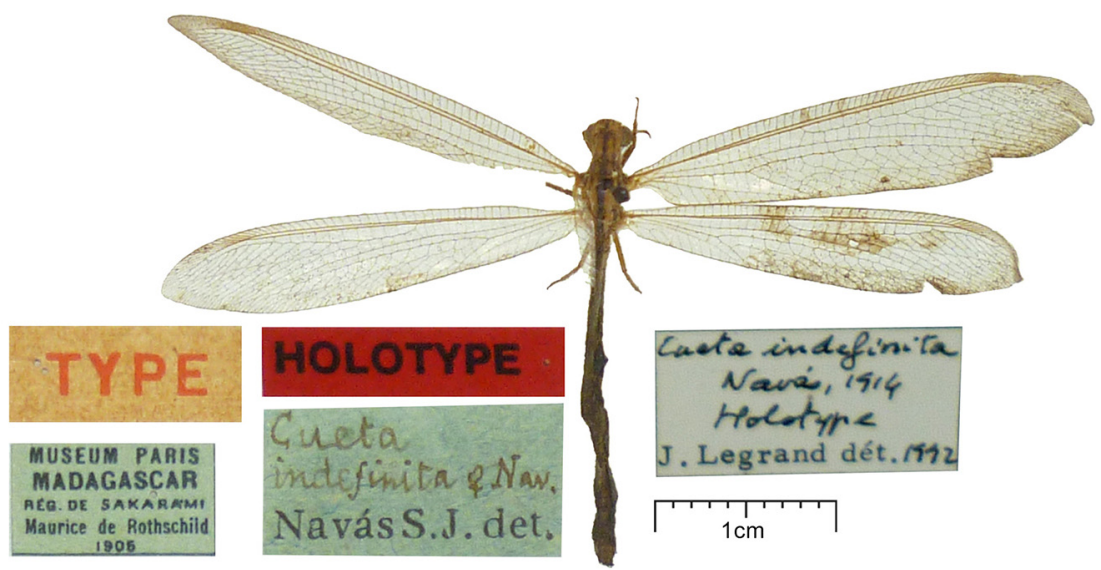

Fig. 6: Lectotype of Cueta indefinita Navás, 1914

Comment. It is only one and valid Cueta Navás, 1911 taxon from Madagascar. Navás (1914b, 1934a) described four Cueta sp. from Madagascar namely Cueta externa Navás, 1914; Cueta gracilis Navás, 1914; Cueta pilosa Navás, 1934; Cueta simplicior Navás, 1934. Cueta pilosa is a homonym of Cueta pilosa Navás, 1917 from Vietnam revealed by Stange (2004) otherwise the four taxa are new synonyms of Cueta indefinita Navás, 1914. Type of Cueta indefinita Navás, 1914 is only a lectotype specimen. ÁBRAHÁm \& Dobosz (2011) have already referred to the possible synonymy of Cueta species described from Madagascar.

Distribution of Cueta indefinita. Madagascar. 
Type of Cueta externa. Checked, preserved in MNHP.

LECTOTYPE (present designation): female "/ Lectotype / Cueta externa / Navás, 1914 / design.: Ábrahám \& / Giacomino 2017 [red label] /".

Label information. "/ Type [white label in red letters] // Museum Paris / Madagascar / Prov. De Tulear / Bas Fiherena / F. Geay 1906 [blue label] // Cueta / externa §ิ Nav. [with Navás's handwriting] / Navás S.J. det. [printed] [blue label] // Mission / F. Geay / madagascar / bas Fiherena / $\mathrm{n}^{\mathrm{o}}=5414$ jan. 1906 [white label handwritten] // Holotype red label in capital printed letters // Cueta externa / Navás, 1914 / Holotype $q$ / J. Legrand dét, 1992 [white label] /".

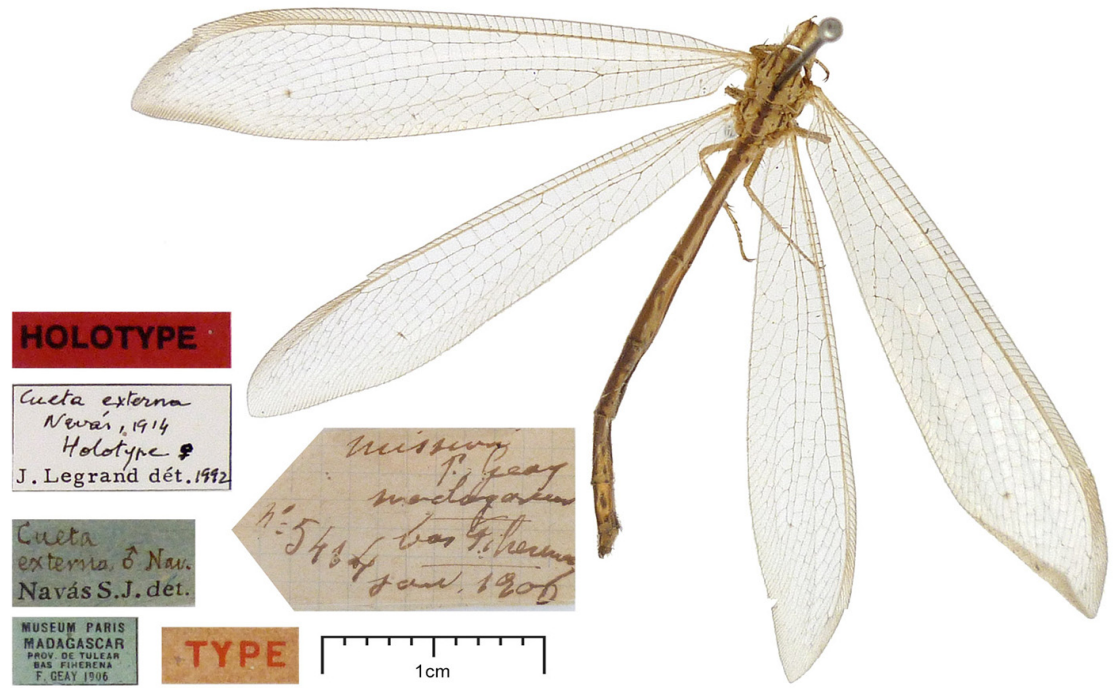

Fig. 7: Cueta externa Navás, 1914 n. syn. of Cueta indefinita Navás, 1914

In Navás (1914b) "Madagascar, Prov. de Tulear, Bas Fiherena".

Synonymy is marked as "/ Cueta indefinita / Navás, 1914 / syn.: Ábrahám \& / Giacomino 2017 [white label in printed letters]/".

Type condition. According to Navís (1914b) the type material was in pure condition (missing head) when describing. The type condition probably has not changed since his describing. The designated lectotype specimen has not a head, too.

Comment. At first, the type specimen was designated by Legrand as holotype based on labels and missing head. NAvís (1914b) marked the sex of type as a male on the original label but the type specimen is a female in which we agree with Legrand.

Type of Cueta gracilis. Lectotype male checked, preserved in MNHP.

Lectotype was designated by Legrand "/ Lectotype [red label in capital printed letters] // Cueta gracilis / Navás, 1924 / Lectotype / J. Legrand dét. 1992 [white label with Legrand's handwriting] /".

Label information. "/ Type [white label in red letters] // Museum Paris / Madagascar S/ District de Tsihombé / Beloha / Lieut. Decary 1919 [blue label] // Beloha 5.3. [19]18 [white label with handwriting] // Cueta / gracilis Nav. [with Navás's handwriting] / det. Navás S. J. [printed] [blue label] /". 


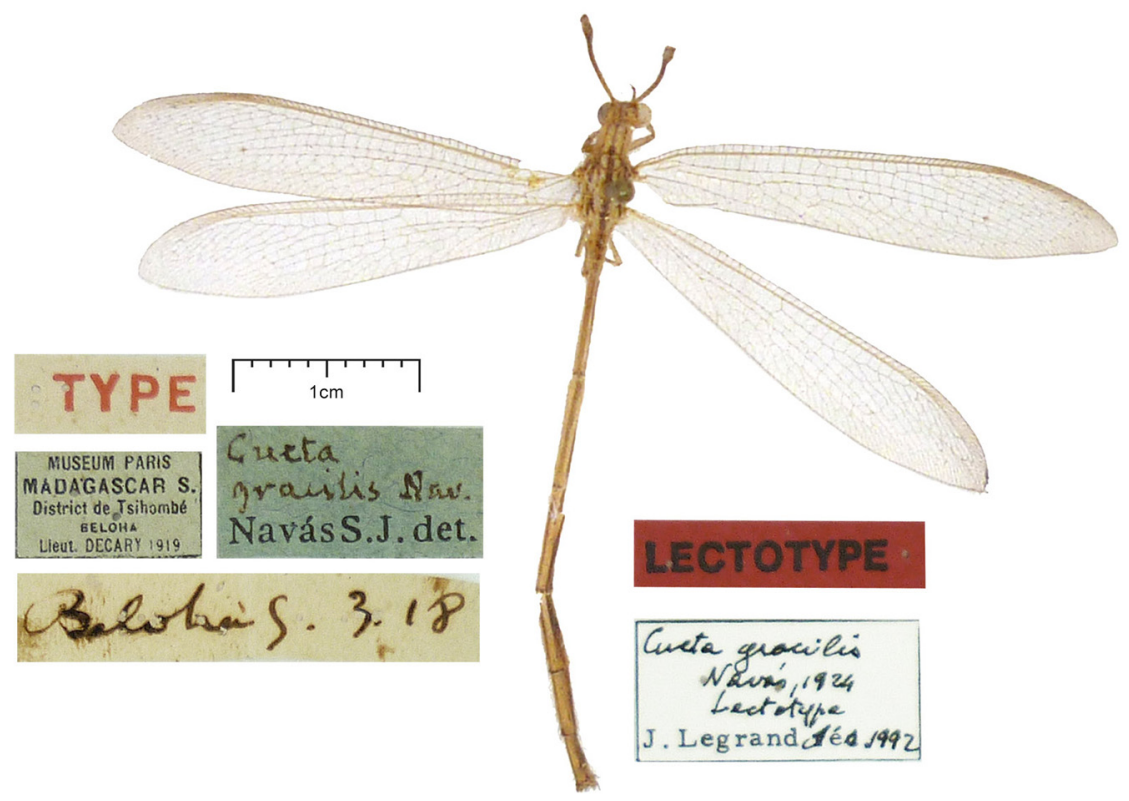

Fig. 8: Cueta gracilis Navás, 1924 n. syn. of Cueta indefinita Navás, 1914

In NavÁs (1924) "Madagascar S., District de Tsihombé, Beloha, Lieut. Decary, 1919". Synonymy is marked as "/ Cueta indefinita / Navás, 1914 / syn.: Ábrahám \& / Giacomino 2017 [white label in printed letters]/".

Type condition. Good, left forewing damaged at the base of costal area.

Comment. Cueta gracilis Navás, 1924 is a new synonym of Cueta indefinita Navás, 1914.

Type of Cueta simplicior. Checked, preserved in MNHP.

Lectotype was designated by Legrand "/ Lectotype [red label in capital printed letters] // Cueta simplicior / Navás, 1934 / Lectotype / J. Legrand dét. 1992 [white label with Legrand's handwriting] /".

Label information. "/ Type [white label in red letters] // Betroka / Madagascar / I. 1933 [blue label with Navás's handwritting] // Cueta / simplicior Nav. [with Navás's handwritting] / det. Navás S.J. [printed] [blue label] // Museum Paris / Login Navas legit 19 [blue label] /".

In Navás (1934a) "Madagascar, Enero de 1933".

Synonymy is marked "/ Cueta indefinita / Navás, 1914 / syn.: Ábrahám \& / Giacomino 2017 [white label in printed letters]/".

Type condition. Good, antenna broken, the abdomen is glued to a label.

Comment. Cueta simplicior Navás, 1934 is a new synonym of Cueta indefinita Navás, 1914. 


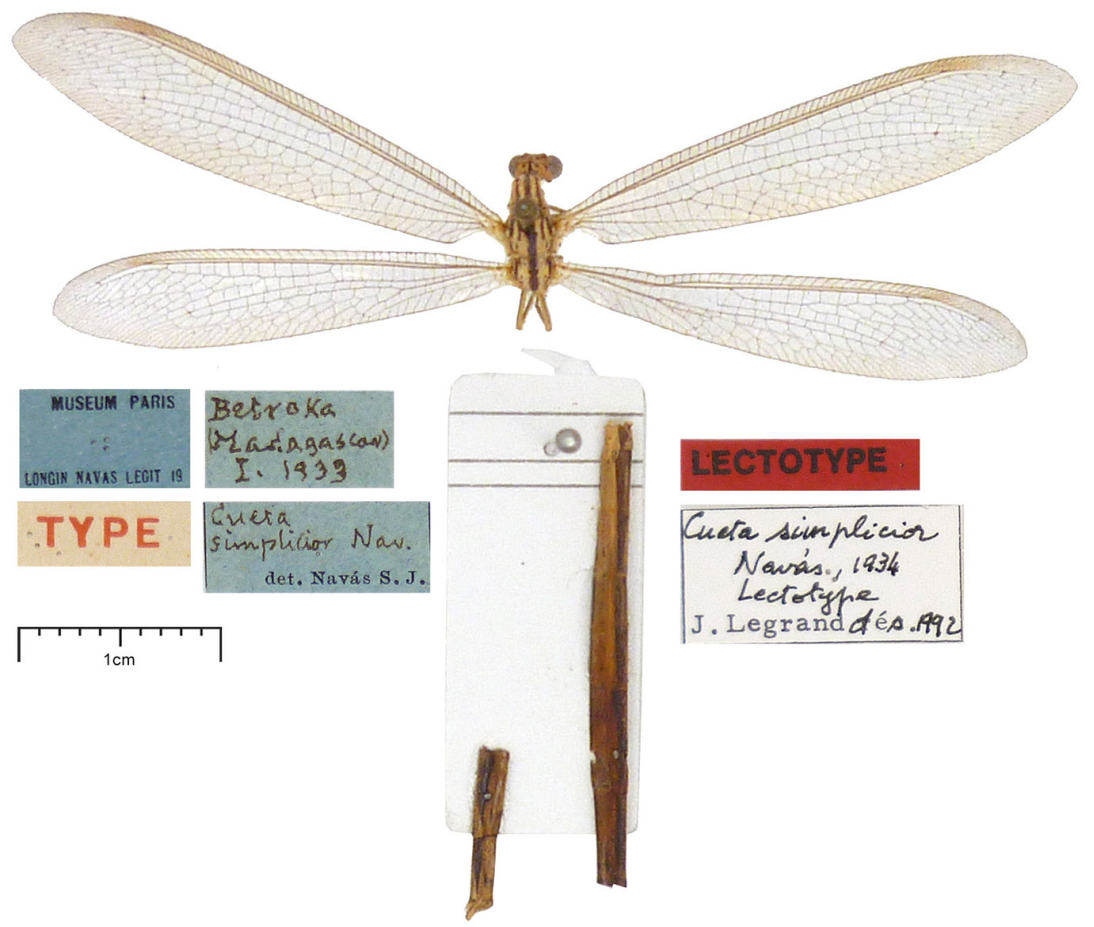

Fig. 9: Cueta simplicior Navás, 1934 n. syn. of Cueta indefinita Navás, 1914

Type of Cueta pilosa. Checked, preserved in MNHP.

LестотYPE (present designation): male "/ Lectotype / Cueta pilosa / Navás, 1934 / design.: Ábrahám \& / Giacomino 2017 [red label] /".

Label information. "/ Type [white label in capital red letters] // Ihossy / Madagascar / II - 1933 [blue label with Navás's handwriting] // Cueta / pilosa Nav. [with Navás’s handwriting] / P. Navás S. J. det. [printed] [green label] // Museum Paris / Longin Navas Legit 19 [blue label in printed letters] /".

In Navás (1934a) "Madagascar: Ihosy, Febrero de 1933; Bekily, Abril de 1933".

Synonymy is marked as "/ Cueta indefinita / Navás, 1914 / syn.: Ábrahám \& / Giacomino 2017 [white label in printed letters]".

Type condition. Good, apart from lacking of antenna.

Comment. Cueta pilosa Navás, 1934 is a new synonym of Cueta indefinita Navás, 1914. It is both homonym and synonym too, only one and same species, Cueta indefinita Navás, 1914 is known from Madagascar.

Cueta pallens (Klug in Ehrenberg, 1834): 36 (Odescr).

Cueta pallens (Klug in Ehrenberg, 1834)

Syn. Nesoleon scalaris Navás, 1912c: 126 (Odescr), syn. n., (Fig. 11).

Cueta scalaris (Navás, 1912) - Stange 2004 (Mon, Comb).

Type of Nesoleon scalaris. Checked, preserved in BMNH.

LестотуPE (present designation): female "/ Lectotype / Nesoleon scalaris Navás, 1912 / design.: Ábrahám \& / Giacomino 2019 [red label] /". 


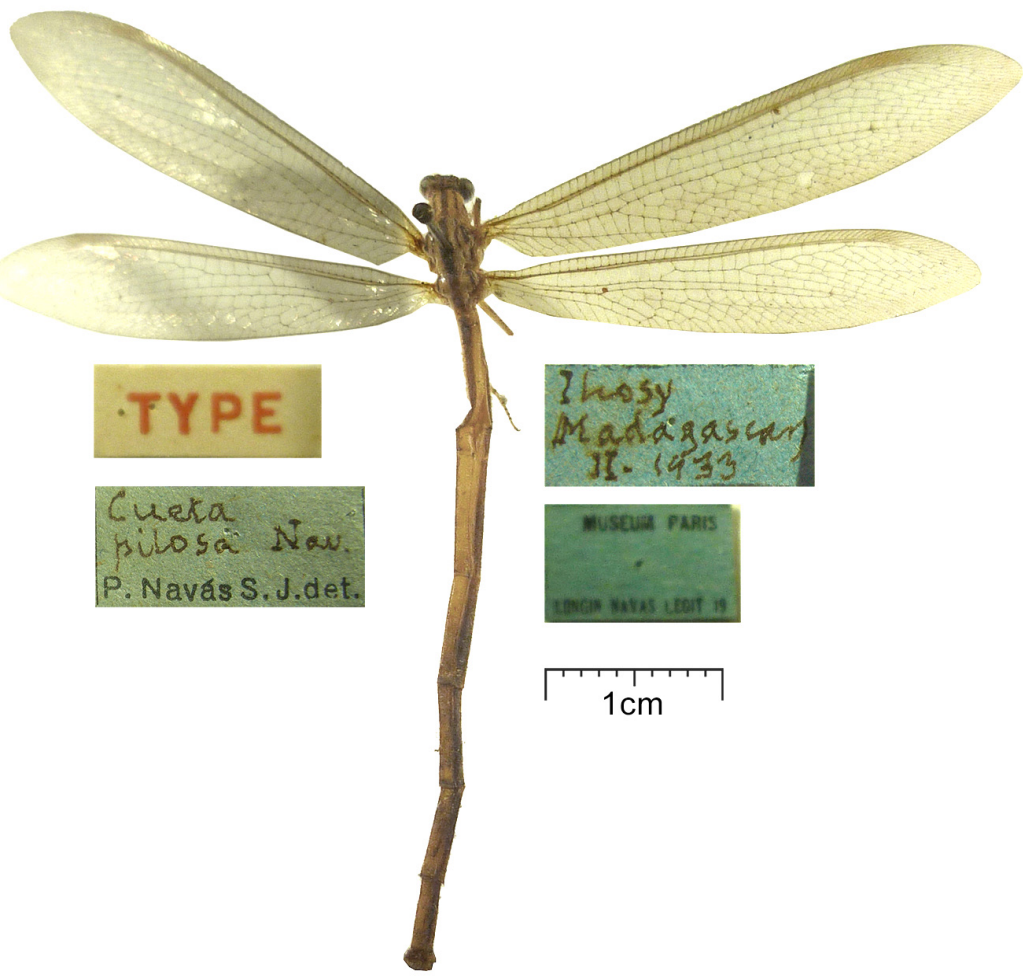

Fig. 10: Cueta pilosa Navás, 1934 n. syn. of Cueta indefinita Navás, 1914

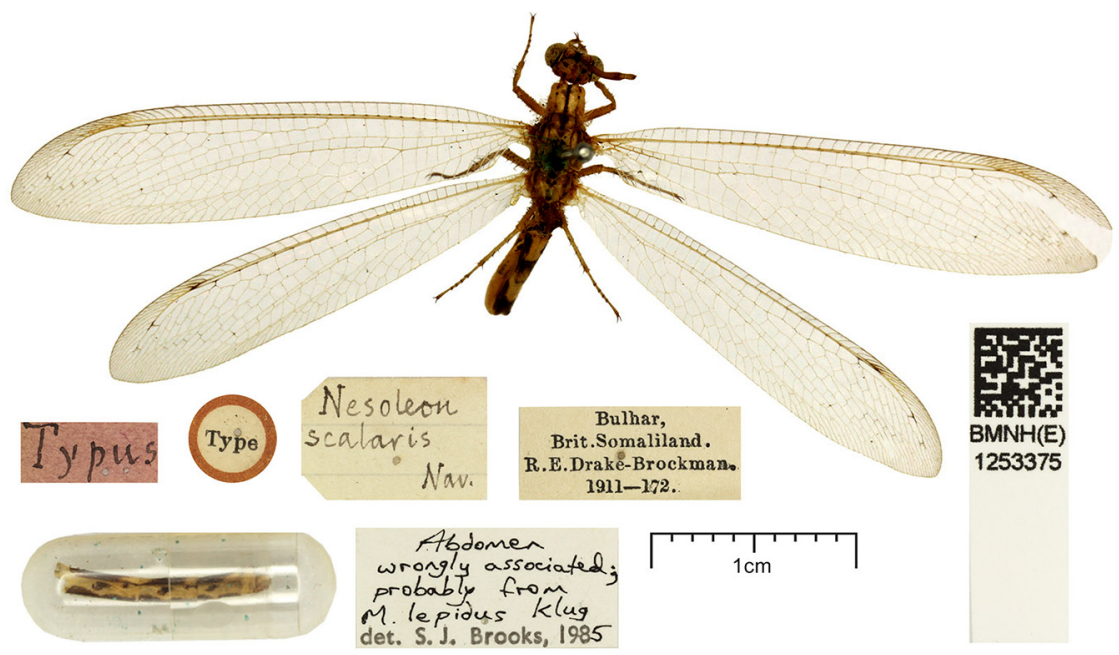

Fig. 11: Nesoleon scalaris Navás, 1912 n. syn. of Cueta pallens (Klug in Ehrenberg, 1834) 
Label information. "/ Type [round shaped white label with red margin] // Typus [red label with Navás's handwriting] // Bulhar / Brit. Somaliland / R. D. Drake-Brockman / 1911 - 172 [white label] // Nesoleon / scalaris Nav. [white label with Navás's handwriting] // Abdomen / wrongly associated; / probably from M. lepidus Klug / det. S. J. Brooks 1985 [white label] // QR code / BMNH(E) / 1253375 [white label] /.

In NAvÁs (1912c) "Afrique orientale, Bulhar, Somaliland, R. D. Drake Brockman, 1911".

Synonymy is marked as "/ Cueta pallens / (Klug in Ehrenberg, 1834) / syn.: Ábrahám \& / Giacomino 2019 [white label in printed letters]/".

Type condition. Poor, abdomen missing.

Comment. Cueta scalaris Navás, 1912 is a new junior synonym of Cueta pallens (Klug in Ehrenberg, 1834). Based on the original description (NAvÁs 1912c), the broken abdomen was glued to the type specimen before description. The label pinned by Brooks to the type specimen is correct, the glued abdomen belongs to Nohoveus lepidus (Klug in Ehrenberg, 1834). This glued type specimen was named by BANKs (1913) as "Nesoleon lepidus Klug." which is a wrong combination and is not extant species.

Distribution of Cueta pallens. Also a widely distributed species in the Saharan zone known in North Africa from Morocco (ÁBrAHÁm 2017) to Egypt, and in East Africa: Sudan (Esben-Petersen 1931), Kenya (in coll. Rippl-Rónai Museum, Kaposvár), in Asia: Israel and Saudi Arabia (Hölzel 1982, AsPöcK et al. 2001). Fraser $(1950,1951)$ published two uncertain distribution data from Niger and Madagascar.

Cueta trivirgata (Gerstaecker, 1885)

Cueta trivirgata (Gerstaecker, 1885): 32 (Odescr).

Syn. Cueta dissimulata Navás, 1913a: 269 (Odescr), Stange 2004 (Mon), Mansell 2018 (Syn), (Fig. 12).

Type of Cueta dissimulata. Checked, preserved in BMNH.

LECTOTYPE (present designation): male "/ Lectotype / Cueta dissimulata Navás, 1913 / design.: Ábrahám \& / Giacomino 2019 [red label] /".

Label information. "/ Type H.T [round shaped white label with red margin] // Typus [red label with Navás's handwriting] // Pretoria / (W. L. D.) [white label] // Distant coll. / 1911 - 383. [white label] // Cueta / dissimulata Nav. [with Navás's handwriting] / Navás S.J. det. [printed] [white label] // QR code / BMNH(E) / 1253369 [white label in printed letters] /".

In NAvÁs (1913a) "Pretoria W. L. D."

Type condition. Excellent.

Comment: Cueta dissimulata Navás, 1913 is a synonym of Cueta trivirgata (Gerstaecker, 1885). The status of the species was revealed by MANSELL (2018), although it has not been published yet. There has not been any information of the species since the description (NAVÁs 1913a).

Distribution of Cueta trivirgata. It occurs in the southern part of Africa. However, its real distribution is unclear because it is very similar to Cueta punctatissima (Gerstaecker, 1894).

Tribe Dendroleontini Banks, 1899

Gatzara caelestis (Krivokhatsky, 1997)

Dendroleon caelestis Krivokhatsky, 1997: 663 (Odescr).

Syn. Dendroleon qiongana Yang, 2002 - Yang et Wang 2002: 296 (Odescr), n. syn., (Fig. 13).

Gatzara qionganus (Yang, 2002) - Wan et al. 2004 (Comb).

Gatzara qiongana (Yang, 2002) - Wang et al. 2012 (Comb), 2018 (Mon), Yang et al. 2018 (Chlist). 


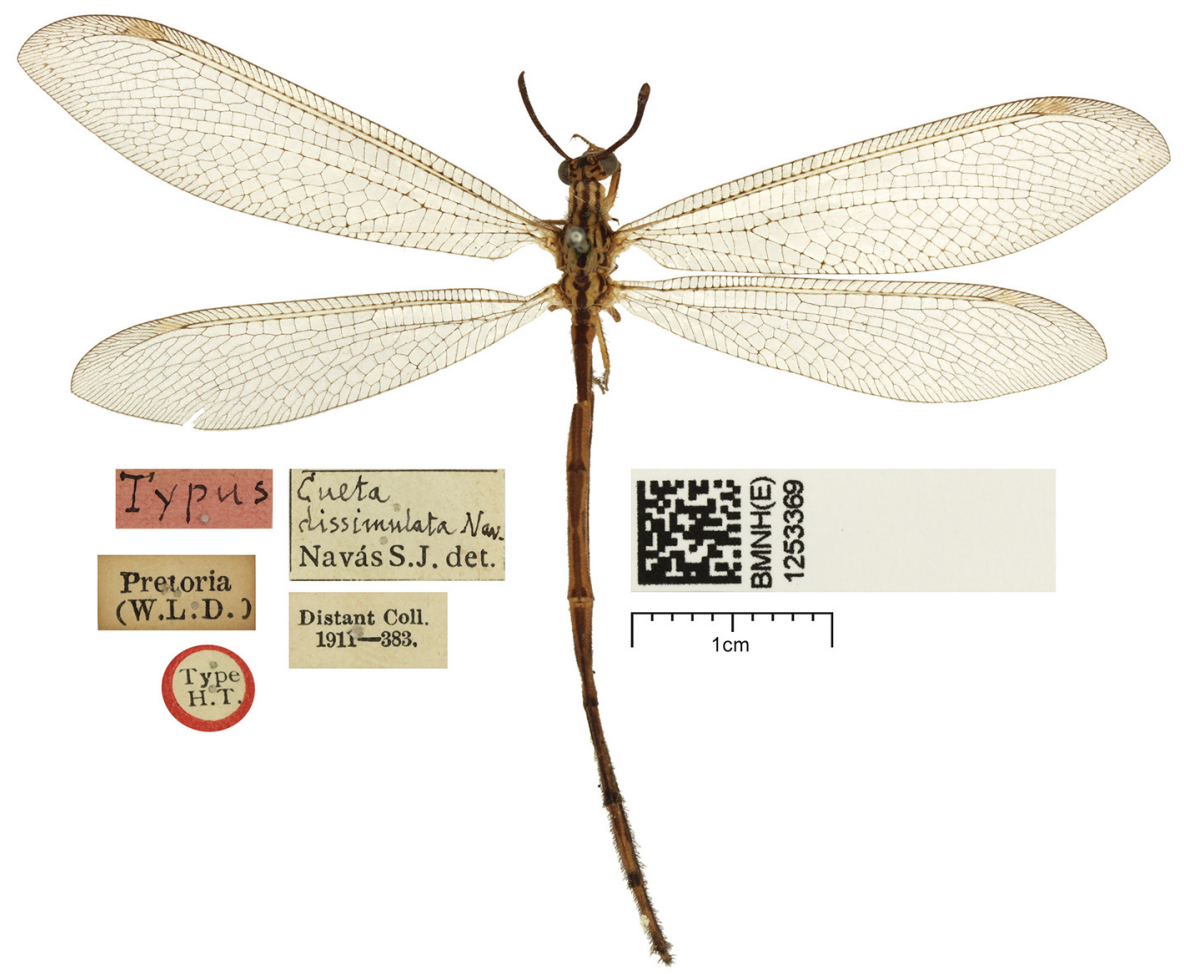

Fig. 12: Cueta dissimulata Navás, 1913 synonym of Cueta trivirgata (Gerstaecker, 1894)

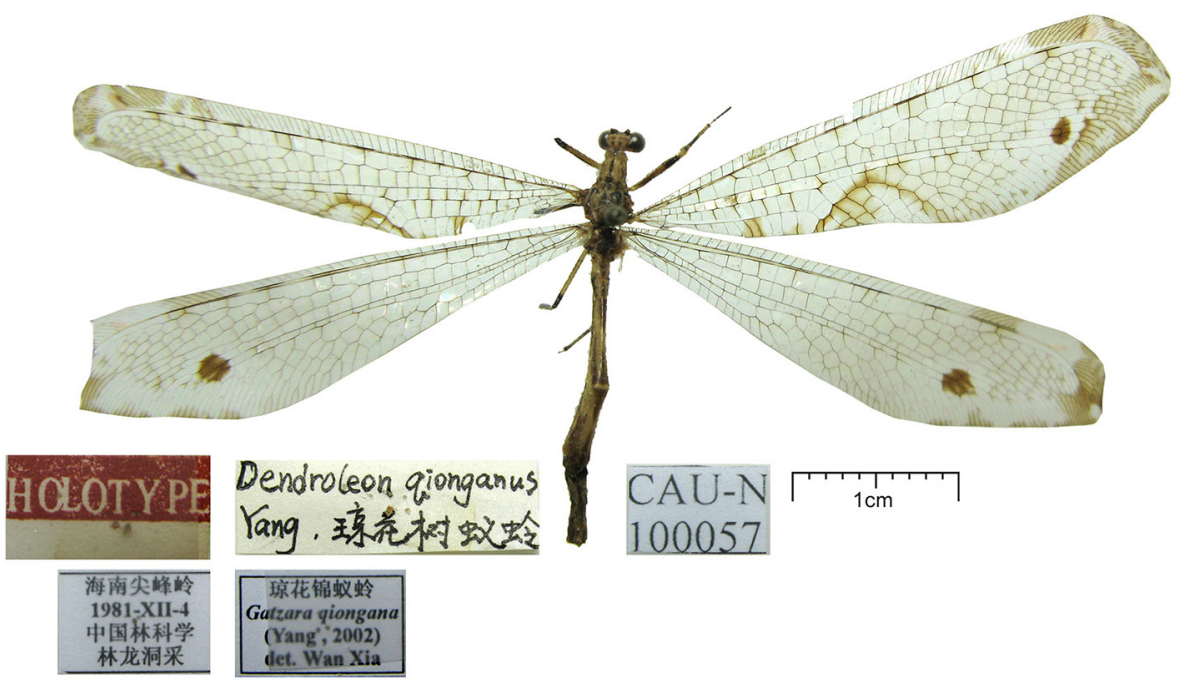

Fig. 13: Dendroleon qiongana Yang, 2002 n. syn. of Gatzara caelestis (Krivokhatsky, 1997) 
Type of Dendroleon qiongana: Holotype female checked, preserved in CAUB.

Label information. "/ Holotype [white label in red brand in capital white letters] // ????? [handwritten in Chinese] / 1981-XII-4 / ????? [handwritten in Chinese] / ????? [handwritten in Chinese] [white label with black upper and lower margins] // ????? [handwritten in Chinese] / Gatzara qiongana / (Yang, 2002) / det. Wan Xia [white label with black margin] // CAU-N / 100057 [white label with black upper and lower margins] /".

In YANG \& WANG (2002) "Holotype +, Hainan Prov. Jianfanling, 1981. XII. 4."

Type condition. Good, antennae missing.

Comment. Gatzara qiongana (Yang, 2002) is a new junior synonym of Gatzara caelestis (Krivokhatsky, 1997).

Distribution of Gatzara caelestis. The occurrence is known in SE Asia: Vietnam (KrivoKhatsky 1997), China (YANG \& WANG 2002, WAN et al. 2004, WANG et al. 2012, 2018).

Gatzara jubilaea Navás, 1915

Gatzara jubilaea Navás, 1915a: 386 (Odescr).

Syn. Dendroleon angulineurus C.-k. Yang, 1987: 212 (Odescr), Stange 2004 (Mon), n. syn., (Fig. 14).

Gatzara angulineurus (C.-k. Yang, 1987) - Wan et al. 2004 (Comb).

Gatzara angulineura (C.-k. Yang, 1987) - Wang et al. 2012 (Comb), 2018 (Mon).

Type of Dendroleon angulineurus. Holotype checked, preserved in CAUB.

Label information. "/ Holotype [white label in red brand in capital white letters] // ????? [handwritten in Chinese] / $2400 \mathrm{~m} /$ 1975-VII-22 / ????? [handwritten in Chinese] [white label with black upper and lower margins] // ????? [handwritten in Chinese] / Gatzara angulineurus / (Yang, 1987) / det. Wan Xia [white label with black upper and lower margins] // CAU-N / 100048 [white label with black upper and lower margins] /". In YANG (1987) "Holotype $\hat{\jmath}$, Tibet Gyirong Co. $2400 \mathrm{~m}$ (1985-VI-22, Huang Fu-seng)".

Type condition. Medium, left antenna and tip of abdomen missing.

Comment. Gatzara angulineura (C.-k. Yang, 1987) is a new junior synonym of Gatzara jubilaea Navás, 1915. There are slight differences between the label data of the holotype and the published data.

Distribution of Gatzara jubilaea. Published data are known from China (Xizang) (YANG 1987, WANG et al. 2018) and India (NAvÁs 1915a, 1929, 1930b, GHosh \& SeN 1977, WhitTington 2002). There are unpublished data of specimens from Nepal (in coll. Rippl-Rónai Museum, Kaposvár).

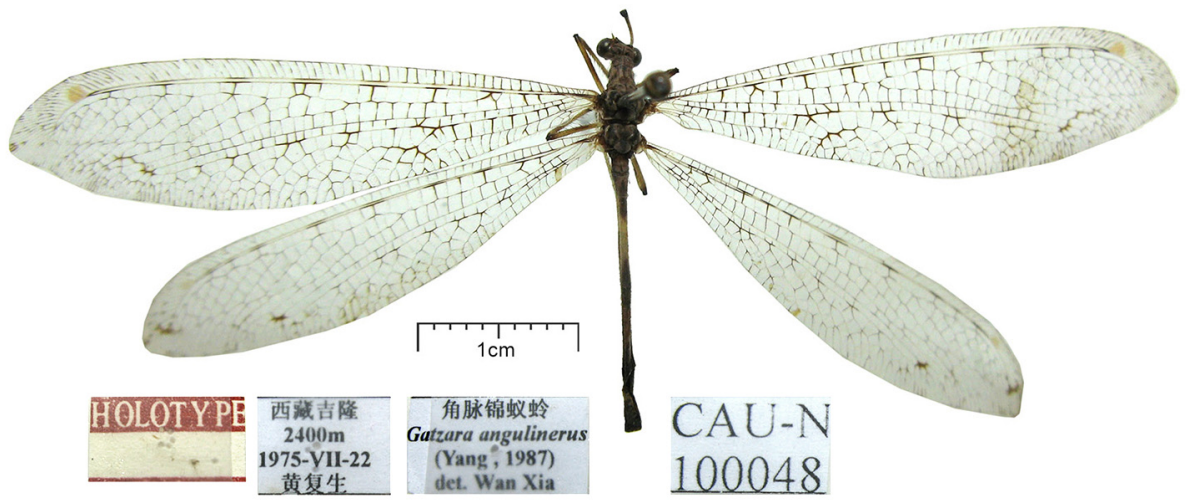

Fig. 14: Dendroleon angulineurus C.-k. Yang, 1987 n. syn. of Gatzara jubilaea Navás, 1915 


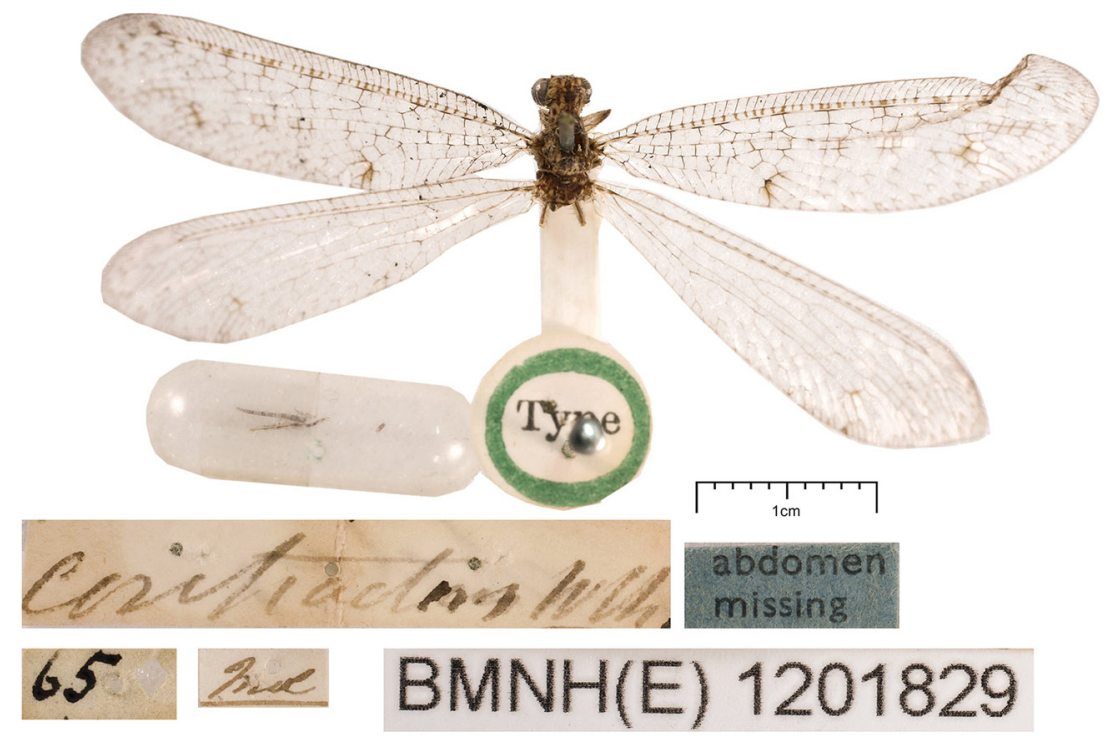

Fig. 15: Lectotype of Myrmeleon contractus (Walker, 1860)

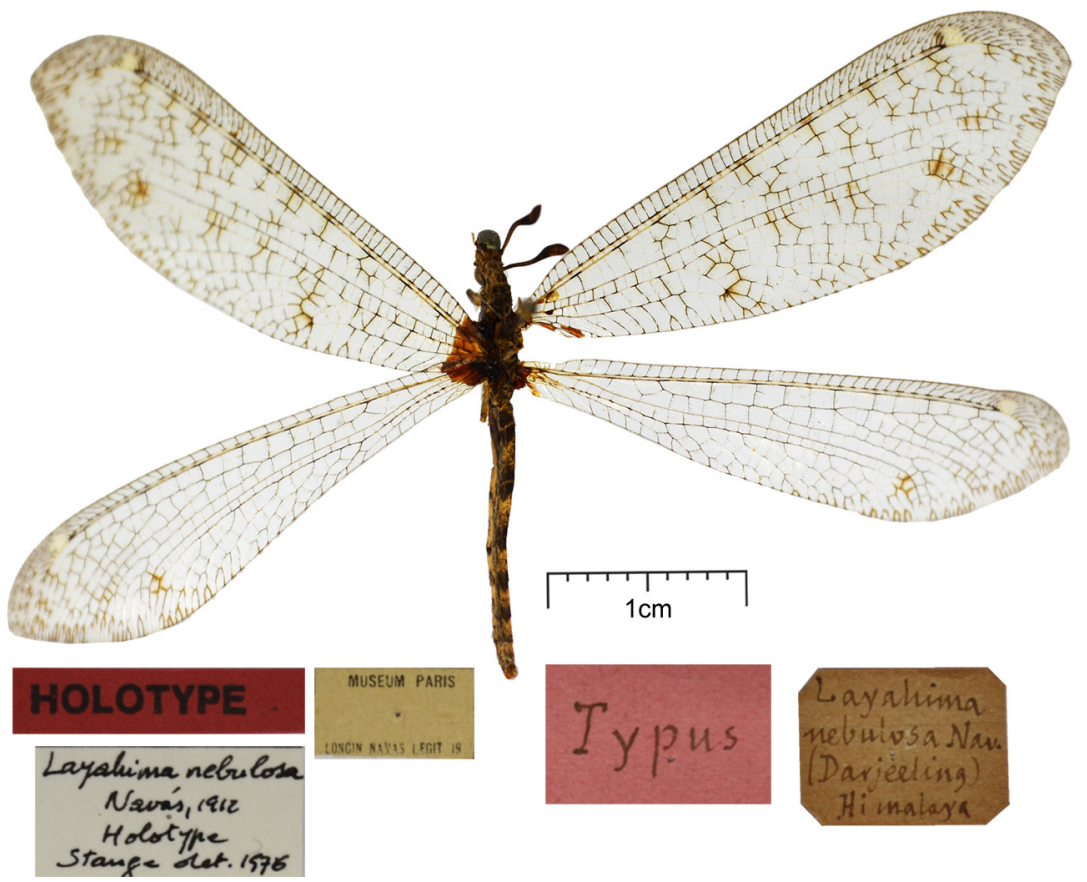

Fig. 16: Layahima nebulosa Navás, 1912 n. syn. of Layahima contracta (Walker, 1860) 
Layahima contracta (Walker, 1860) n. comb.

Myrmeleon contractus Walker, 1860: 192 (Odescr), Stange 1976 (Tax), 2004 (Mon), Gravely \& Maulik 1911 (larva), (Fig. 15).

Syn. Layahima nebulosa Navás, 1912a: 36 (Odescr), 1926a (Dist), Ghosh 1984 (Mon), 2000 (Mon), Ghosh \& Sen 1977 (Chlist), Whittington 2002 (Dist), n. syn., (Fig. 16).

Type of Layahima contracta. Checked, preserved in BMNH.

LECTOTYPE (present designation): female "/ Lectotype / Myrmeleon contractus

Walker, 1860 / design.: Ábrahám \& / Giacomino 2019 [red label] /".

Label information. "/ Type [round shaped white label with green margin] // 65 [white label] // Ind.[ia] [white label] // contractus Wlk. [white label handwritten] // abdomen / missing [blue label] // BMNH(E) / 1201829 [white label] /".

In WALKER (1860) "Hindostan".

Type condition. Medium, abdomen and antannae missing.

Comment. Myrmeleon contractus Walker, 1860 is moved to Layahima Navás, 1912.

Distribution of Layahima contracta. India (WALKer 1860, GHOSH \& SEN 1977).

Type of Layahima nebulosa. Checked, preserved in MNHP.

LECTOTYPE (present designation): female "/ Lectotype / Layahima nebulosa Navás, 1912 / design.: Ábrahám \& / Giacomino 2017 [red label] /".

Label information. "/ Typus [red label with Navás's handwriting] // Layahima / nebulosa Nav. / (Darjeeling) / Himalaya [white label with Navás's handwriting] // Muséum Paris / Login Navás Legit 19 [white label in printed letters] // Holotype [red label in capital letters] // Layahima nebulosa / Navás, 1912 / holotype / Stange det. 1976 [white label with Legrand's handwriting] /".

In NAVÁs (1912a) "Darjeeling en el Himalaya".

Synonymy is marked as "/ Layahima contracta / (Walker, 1860) / syn.: Ábrahám \& / Giacomino 2017 [white label in printed letters]/".

Type condition. Bad, wings broken but glued.

Comment. Layahima nebulosa Navás, 1912 is a new junior synonym of Layahima contracta (Walker, 1860). The type is not a holotype but only a lectotype.

Tribe Nemoleontini Banks, 1911

Banyutus cubitalis (Navás, 1914) n. comb.

Formicaleo cubitalis Navás, 1914d: 252 (Odescr), (Fig. 17).

Distoleon cubitalis (Navás, 1914) - Stange 2004 (Comb, Mon).

Syn. Formicaleo feai Navás, 1915a: 389 (Odescr), Poggi 1993 (List), n. syn., (Fig. 18).

Banyutus feai (Navás, 1915) - Krivokhatsky 1997 (Comb).

Syn. Cymatala pallora C.-k. Yang, 1986: 424 (Odescr), Stange 2004 (Mon), Wang et al. 2018 (Mon), Yang et al. 2018 (Chlist), n. syn., (Fig. 19).

Banyutus pallorus (C.-k. Yang, 1986) - n. comb.

Type of Formicaleo cubitalis. Checked, preserved in BMNH.

LECTOTYPE (present designation): male "/ Lectotype / Distoleon cubitalis Navás, 1914 / design.: Ábrahám \& / Giacomino 2019 [red label] /".

Label information. "/ Holo- / type [round shaped white label with red margin] // Typus [red label with Navás's handwriting] // Formicaleo / cubitalis / Nav. [with Navás's handwriting] / Navás S. J. det. [printed] [white label] // N. India [white label] // Brit. Mus. / 1950-553 [white label] // Formicaleo / cubitalis Navás / TYPE / N. India [white label with handwriting] // BMNH(E) 1201822 [white label] /".

In Navís (1914d) "N. India".

Type condition. Good, only antennae missing. 


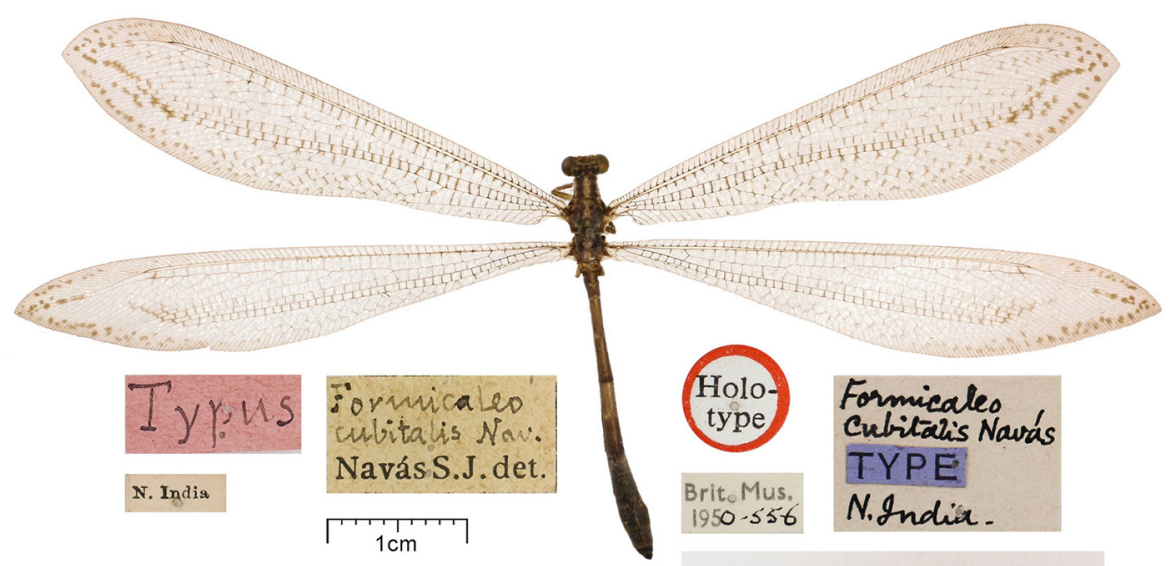

$\mathrm{BMNH}(\mathrm{E}) \cdot 1201822$

Fig. 17: Distoleon cubitalis (Navás, 1914) n. comb. of Banyutus cubitalis (Navás, 1914)

Comment. Distoleon cubitalis (Navás, 1914) (STAnge 2004) is moved to Banyutus Navás, 1912. The type is deposited in BMNH - Natural History Museum, London and not in "(Mus. de Cambridge)" as it was mentioned by Navás (1914d) in the original publication.

Distribution of Banyutus cubitalis. Known in SE Asia: India, Burma (now Mianmar) (Navís 1914d, GHosh \& Sen 1977) and China (Yunnan) (YANG 1986).

Type of Formicaleo feai. Checked, preserved in MCSN.

Syntypes were designated by PoGgi (1993).

Label information. "/ Typus [red label with Navás's handwriting] // Palon / (Pegú) / L.Fea VIII-IX. 87 [white label with narrow black margins] // Formicaleo / Feai / Nav. [with Navás's handwriting] / Navás S. J. det. [printed] [white label] // Syntypus / Formicaleo / feai / Navás 1915 [handwritten] // Museo Civico / di Genova [white label in printed letters] /".

In Navás (1915) "Birmán: Palon (Pegud), L. Fea. VIII-IX. [18]97. (Mus. de Génova)", in Poggi (1993) "[Birmania], Palon, (Pegu), VIII-IX.[18]87, L. Fea."

Type condition. Syntype with typus label is in bad condition, head, legs and distal part of abdomen missing. Otherwise all syntypes are also in very bad conditions.

Comment. Banyutus feai (Navás, 1915) is a new junior synonym of Banyutus cubitalis (Navás, 1914). One of the syntypes is labeled by Krivokhatsky as white label with his handwritting "/ Banyutus 1996 / feai (Nav.) / Krivokhatsky det /". We agree with KRIVOKHATSKY (1997) that Banyutus indicus Navás, 1929 is also a synonym.

Type of Cymotala pallora. Holotype male checked, preserved in CAUB.

Label information. "/ Holotype / $\widehat{O}$ [white label with red upper band] // ???? [handwritten in Chinese] / 1979-IX-18 1800m [white label] // ???? [handwritten in Chinese] / Cymatala / pallora / Yang, 1986 / Det. Jikun Yang [white label with narrow black margins] // CAU-N / 101867 [white label] /".

In YANG (1986) "Holotype male, Yunnan Prov., Lancang Lahu Aut. Co., 1978-V-18". 


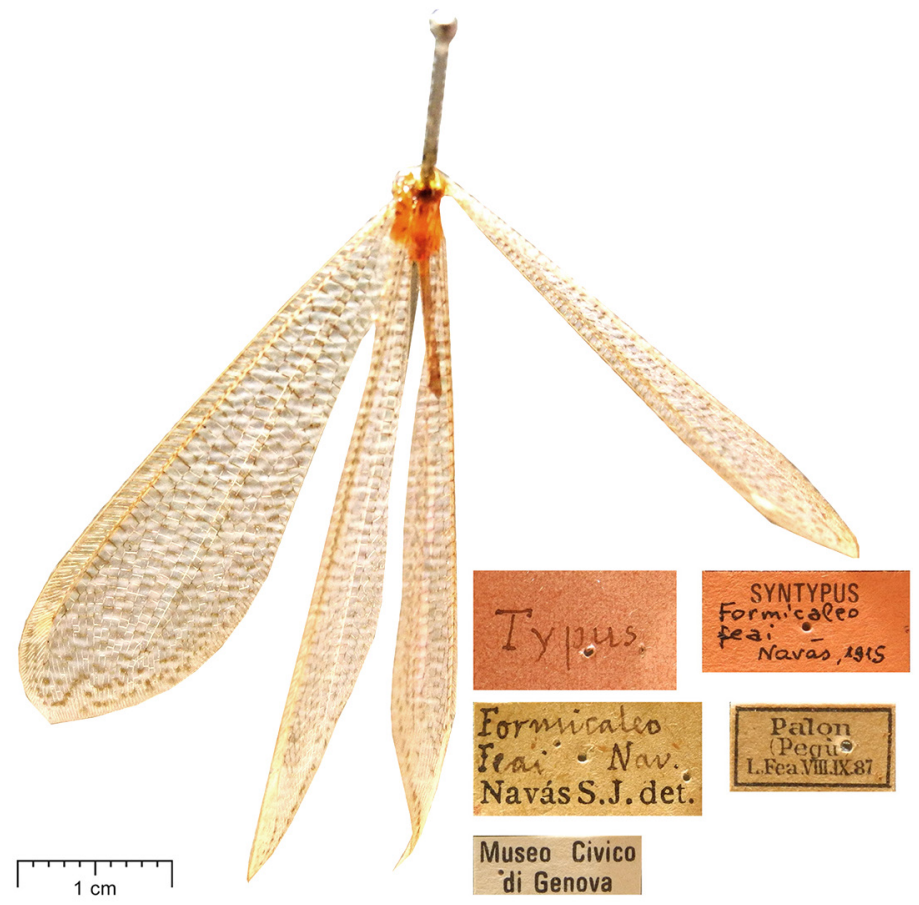

Fig. 18: Formicaleo feai Navás, 1915 n. syn. of Banyutus cubitalis (Navás, 1914)

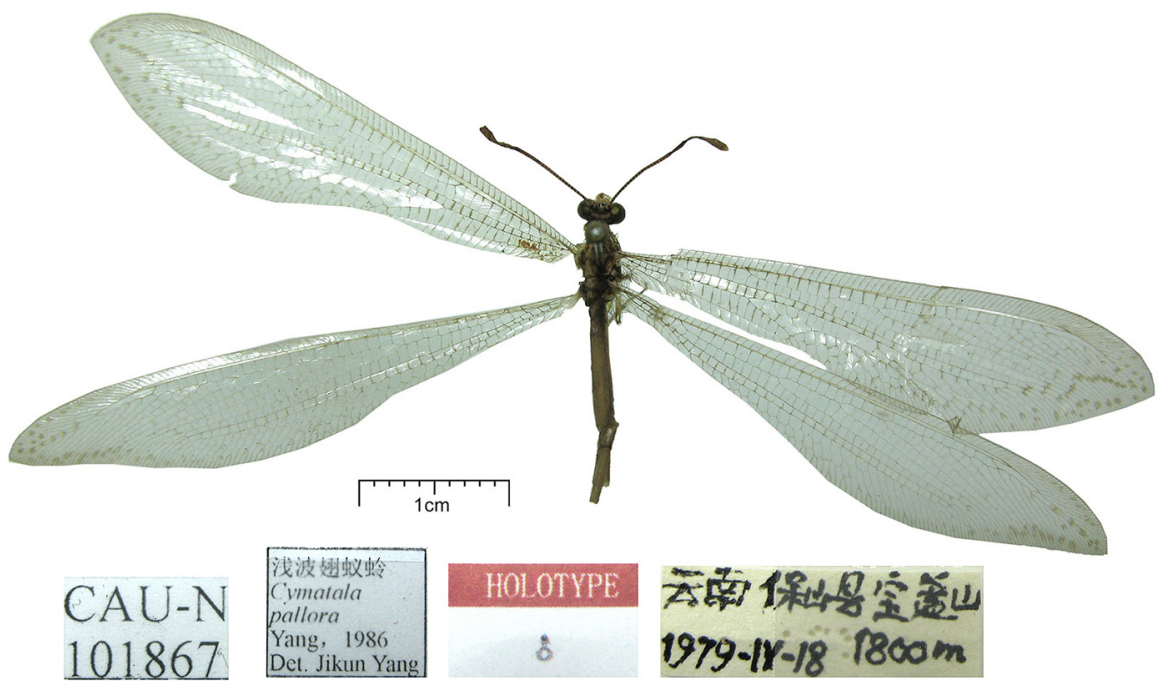

Fig. 19: Cymatala pallora C.-k. Yang, 1986 n. syn. of Banyutus cubitalis (Navás, 1914) 
Type condition. Medium, wings broken and glued, tip of abdomen broken but glued to small paper.

Comment. Cymatala pallora C.-k. Yang, 1986 is moved to Banyutus Navás, 1912. and it is a new junior synonym of Banyutus cubitalis (Navás, 1914).

Creoleon lugdunensis (Villers, 1789): 63 (Odescr).

Syn. Creoleon maurus Navás, 1923: 340 (Odescr), Aspöck \& Hölzel 1996 (Chlist), Aspöck et al. 2001 (Mon), Stange 2004 (Mon), n. syn., (Fig. 20).

Type of Creoleon maurus. Female checked, preserved in MNHP.

Label information. "/ Typus [red label with Navás's handwriting] // Creoleon / maurus Nav. [with Navás's handwriting] / P. Navás S. J. det. [printed] [green label] // Coll. Lacroix [white label] // sons / (Tunisie) [green label with handwriting] // Lectotype [red label in capital letters] // Creoleon maurus / Navás, 1923 / Lectotype / J. Legrand det. 1992 [white label with Legrand's handwritting] /".

In Navás (1923) "Tunisie, Sousse. Coll. Lacroix".

Synonymy is marked as "/ Creoleon lugdunensis / (Villers, 1789) / syn.: Ábrahám \& / Giacomino 2017 [white label in printed letters]/".

Type condition. Medium, antenna lost, apex of forewing incomplete.

Comment. There has not been data on the taxa since the description (NAvís 1923). Aspöck et al. (2001) documented it as nomen dubius due to the type material was lurking or lost. Creoleon maurus Navás, 1923 is a new junior synonym of Creoleon lugdunensis (Villers, 1789).

Distribution of Creoleon lugdunensis. It occurs in the West Mediterranean area, in Europe: Spain, Portugal, France, Italy, Switzerland and in Africa: Morocco, Algeria, Tunesia (AsPöcK et al. 2001). In STANGE (2004), the distribution data of Creoleon lugdunensis (Villers, 1789) are mixed with the data of Creoleon plumbeus (Olivier, 1811).

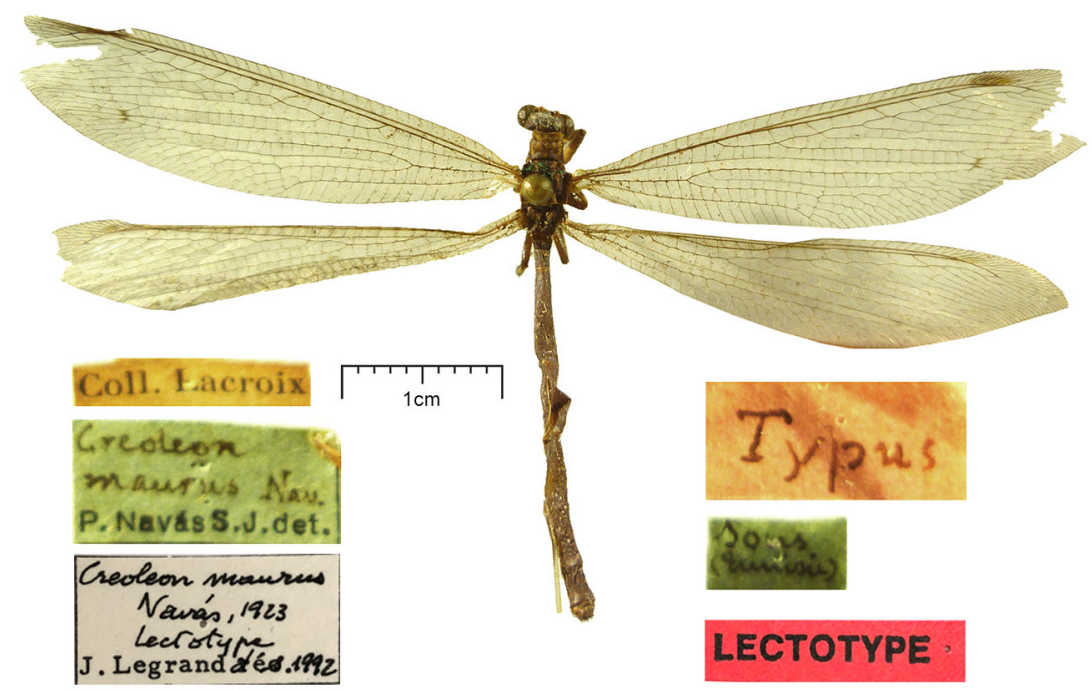

Fig. 20: Creoleon maurus Navás, 1923 n. syn. of Creoleon lugdunensis (Villers, 1789) 
Creoleon mortifer (Walker, 1853)

Creoleon mortifer (Walker, 1853): 353 (Odescr).

Syn. Creagris loanguana Navás, 1913c: 489 (Odescr), n. syn., (Fig. in Trauber et al. 2019).

Creoleon loanguanus (Navás, 1913) - Stange 2004 (Mon, Comb), Tauber et al. 2019 (Tax).

Syn. Creagris venosa Navás, 1914c: 645 (Odescr), n. syn., (Fig. 22).

Creoleon venosus (Navás, 1914) - Stange 2004 (Mon, Comb).

Syn. Creagris interrupta Navás, 1914c: 646 (Odescr), n. syn., (Fig. 23).

Creoleon interruptus (Navás, 1914) - Navás 1933a (Dist, Comb), 1934a (Dist), Penny 2004 (List), Stange 2004 (Mon).

Syn. Creoleon nigritarsis Navás, 1921: 304 (Odescr), Navás 1928 (Dist), Stange 2004 (Mon), n. syn., (Fig. 21). Creoleon nigritarsis Navás, 1911 [sic] - Whittington 2002 (Dist).

Type of Creagris loanguana. Syntype checked, preserved in OXUM.

Label information. "/ Typus [red label with Navás's handwriting] // Creagris / loanguanus / Nav. [with Navás's handwriting] / Navás S.J. det [printed] [white label] // N. E. Rhodesia, / East Loangwa, / Dist. 3-3500 ft., / Mbala country., / Coll. 13-v-1905 / by S. A. Neave. / Pres. '06 by him / and B. S. A. Co. [white label in printed letters] // Type [in capital letters] Neur: No 66 / Creagris loanguana / Navas [handwritten], / Hope Dept. Oxford [in capital letters] [white label with black margins] /".

In Navás (1913c) "N. E. Rhodesia, East Loangwa, Dist. 3-3500 ft., Mbala country, Coll. 13-V-1905, S. A. Neave".

Synonymy is marked as "/ Creoleon mortifer / (Walker, 1853) female / syn.: Ábrahám \& / Giacomino 2019 [white label in printed letters]/".

Type condition. Excellent.

Comment. TAuber et al. (2019) designated and figured a syntype. Creoleon loanguanus (Navás, 1913) is a new synonym of Creoleon mortifer (Walker, 1853).

Distribution of Creoleon mortifer. It is a widespread species especially is the southern hemisphere of Africa but its distribution has not been cleared yet because of many synonyms. All African Creoleon species should be revised in the future.

Type of Creagris venosa. Male checked, preserved in BMNH.

Label information. "/ Typus [red label with Navás's handwriting] // Creagris / venosa / Nav. [with Navás's handwriting] / P. Navás S. J. det. [printed] [blue label] // Bloemfontein / Wilman 1898 [white label in printed letters] // Syn- / type [round label with blue margin in capital letters] // Creagris / venosa Navás [white label with handwriting] / Type [in capital printed letters in blue background] // Brit. Mus. / 1950-556 [white label] // BMNH(E) / 1201828 [white label in printed letters] /".

In Navás (1914c) "Afrimer. Bloemfontein, Wilman, 1898".

Synonymy is marked as "/ Creoleon mortifer / (Walker, 1853) / syn.: Ábrahám \& / Giacomino 2019 [white label in printed letters]/"

Type condition. Good, antennae missing, abdomen broken but stored in genital vial.

Comment. Creoleon venosus (Navás, 1914) is a new synonym of Creoleon mortifer (Walker, 1853).

Type of Creagris interrupta. Checked, preserved in BMNH.

Label information. "/ Typus [red label with Navás's handwriting] // Creagris / interrupta / Nav. [with Navás's handwriting] / P. Navás S. J. det. [printed] [blue label] // Mozambique / F. Muir [white label in printed letters] // Syn- / type [round label with blue margin in capital letters] // Creagris / interrupta Navás [white label with handwriting] / Type [in capital printed letters in blue background] // Brit. Mus. / 1950-556 [white label // BMNH(E) / 1201831 [white label in printed letters] /".

In Navás (1914c) "Mozambique, F. Muir". 


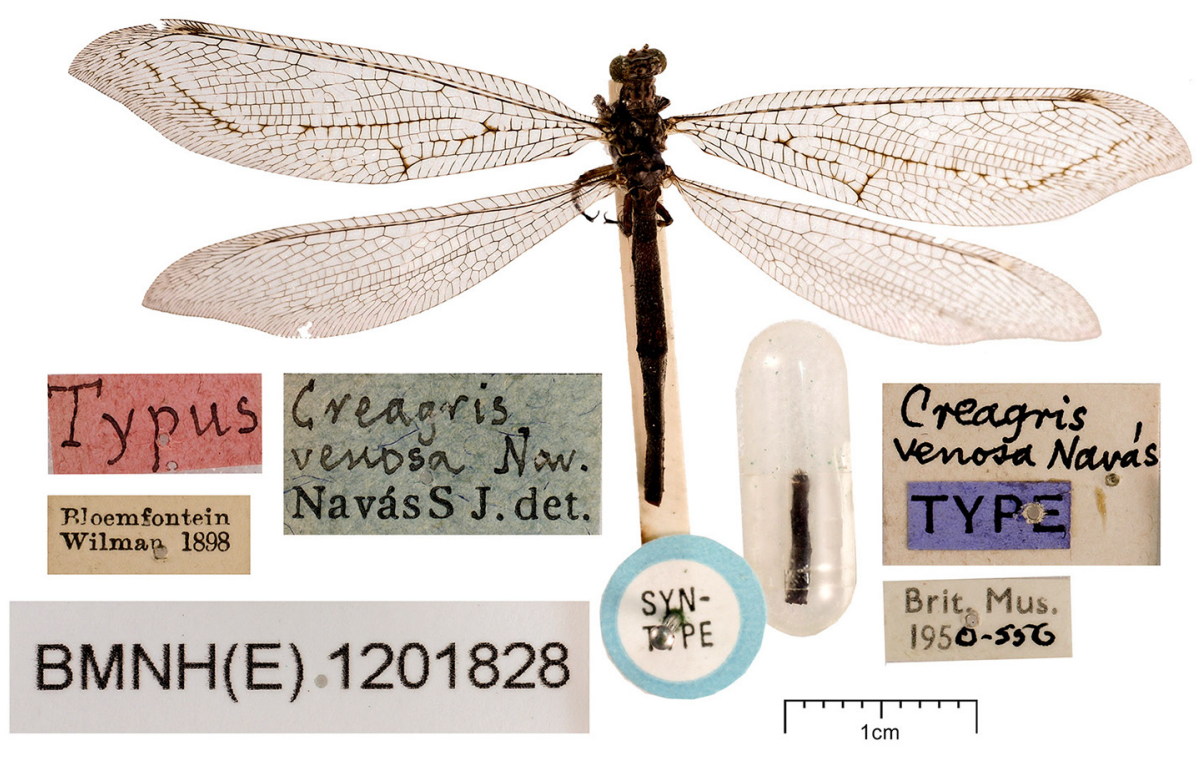

Fig. 22: Creagris venosa Navás, 1914 n. syn. of Creoleon mortifer (Walker, 1853)

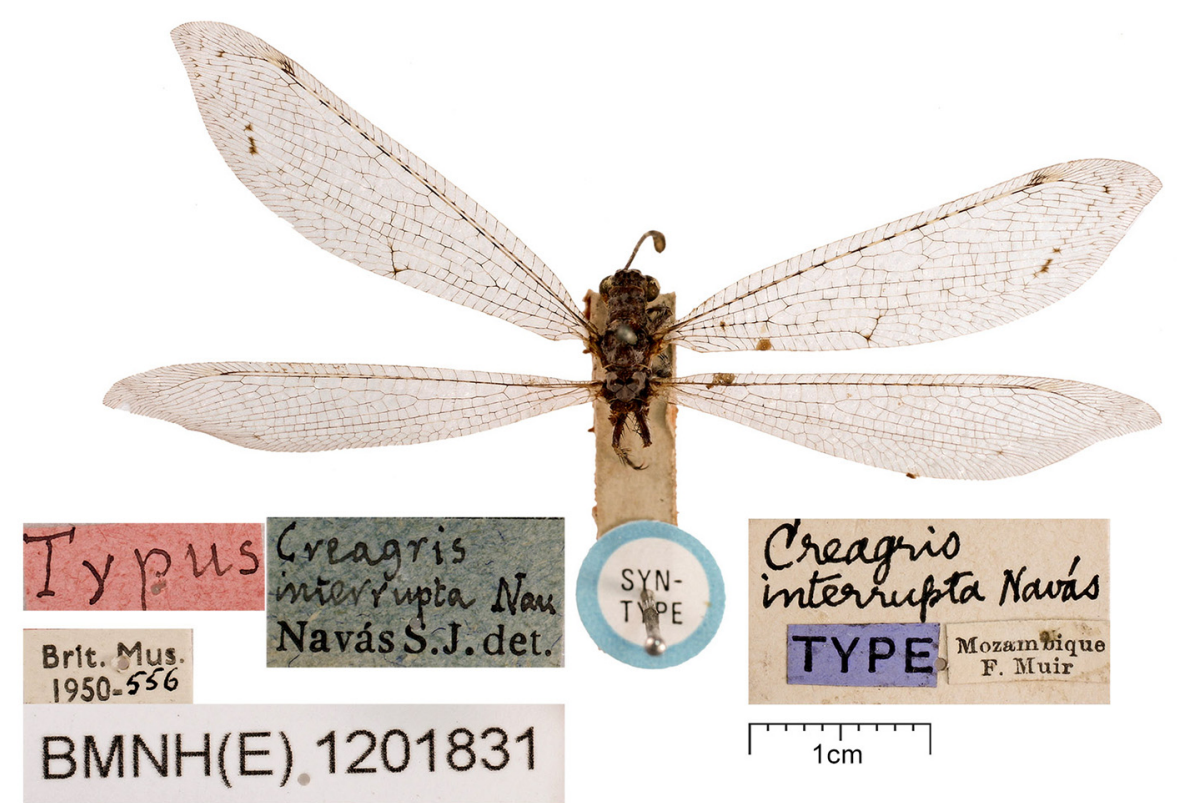

Fig. 23: Creagris interrupta Navás, 1914 n. syn. of Creoleon mortifer (Walker, 1853) 
Synonymy is marked as "/ Creoleon mortifer / (Walker, 1853) / syn.: Ábrahám \& / Giacomino 2019 [white label in printed letters]/".

Type condition. Medium, rigth antenna and abdomen missing.

Comment. Creoleon interruptus (Navás, 1914) is a new synonym of Creoleon mortifer (Walker, 1853). The same distribution data were published by Navís (1933a, 1934a) from Kenya and Madagascar but the collecting site can be found in Madagascar and not in Kenya.

Type of Creoleon nigritarsis. Checked, preserved in MNHP.

Lectotype female was designated by Legrand "/ Lectotype [red label in capital letters] // Creoleon nigritarsis / Navás, 1921 / Lectotype / J. Legrand dét. 1992 [white label with Legrand's handwriting]/".

Label information. "/ Museum Paris / Bechuanaland / Gaberones / R. Ellenberger, 1915 [blue label] // Février [white label] // Type [white label in capital red letters] // Creoleon / nigritarsis Nav. [with Navás's handwriting] / P. Navás S.J. det. [printed] [blue label] /".

In Navás (1919 [1921]) "Bechuanaland: Gaberones, R. Ellenberger, Febrero de 1915".

Synonymy is marked as "/ Creoleon mortifer / (Walker, 1853) / syn.: Ábrahám \& / Giacomino 2017 [white label in printed letters]/"

Type condition. Good, rigth antenna missing.

Comment. Creoleon nigritarsis Navás, 1921 is a new synonym of Creoleon mortifer (Walker, 1853).

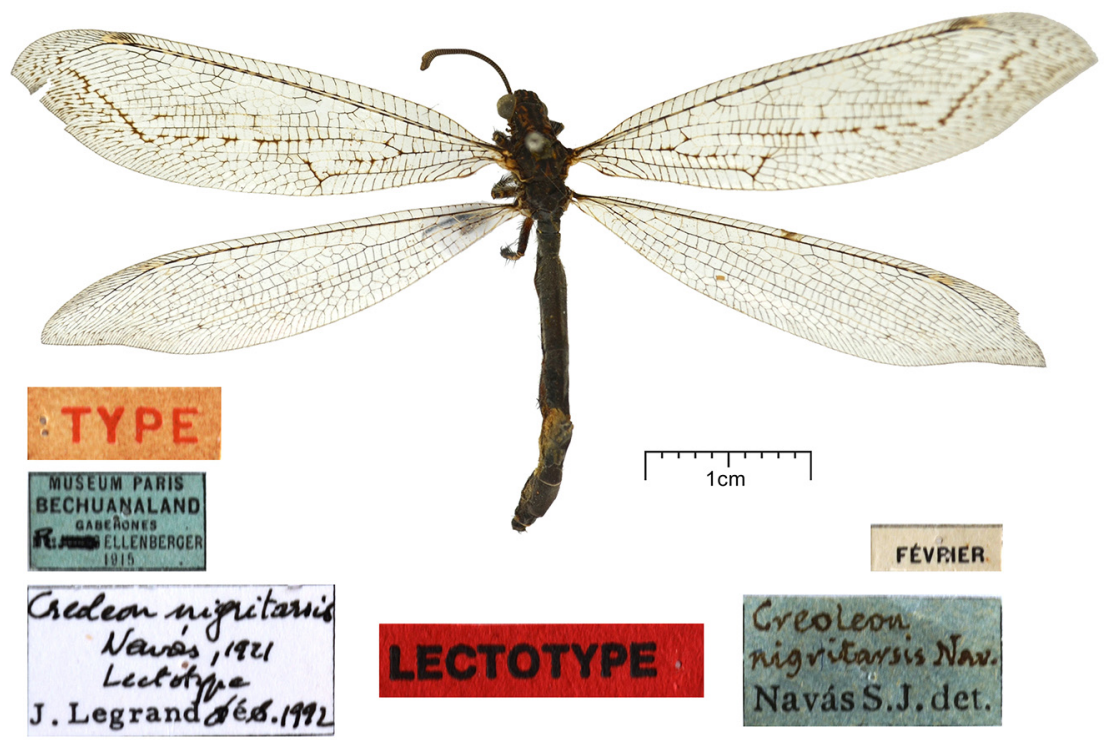

Fig. 21: Creoleon nigritarsis Navás, 1921 n. syn. of Creoleon mortifer (Walker, 1853) 
Distoleon nefandus (Walker, 1853)

Myrmeleon nefendus (Walker, 1853): 357 (Odescr).

Macronemurus nefandus (Walker, 1853) - Hagen 1866 (Comb), McLachlan 1868 (List), Needham 1909 (Dist), Ghosh 1983 (Dist), 1984 (Redescr, Comb), Ghosh \& Sen 1977 (Chlist).

Distoleon nefandus (Walker, 1853) - Stange 2004 (Mon, Comb), (Fig. 24).

Syn. Nelees roscidus Navás, 1937: 1476 (Odescr), n. syn., (Fig. 25).

Neuroleon (Neuroleon) roscidus (Navás, 1937) - Stange 2004 (Mon, Comb).

Distoleon roscidus (Navás, 1937) - n. comb.

Type of Distoleon nefandus. Checked, preserved in BMNH.

LECTOTYPE (present designation). Sex unknown. "/ Lectotype / Myrmeleon nefandus Walker, 1853 / design.: Ábrahám \& / Giacomino 2019 [red label] /".

Label information. "/ Type [round shaped white label with green margin] // nefandus [white label with handwriting] // BMNH(E) / 1201834 [white label] // Abdomen / missing [blue label in printed letters] /".

In WALKER (1853) "North India".

Type condition. Poor, antenna and tip of abdomen missing.

Comment. Valid species.

Distribution of Distoleon nefandus. It is known only in India (Maharashtra, Bihar, Orissa) (Walker 1853, Navás 1937, GHosh 1984). Distoleon Baks, 1910 genus should be revised in the future.

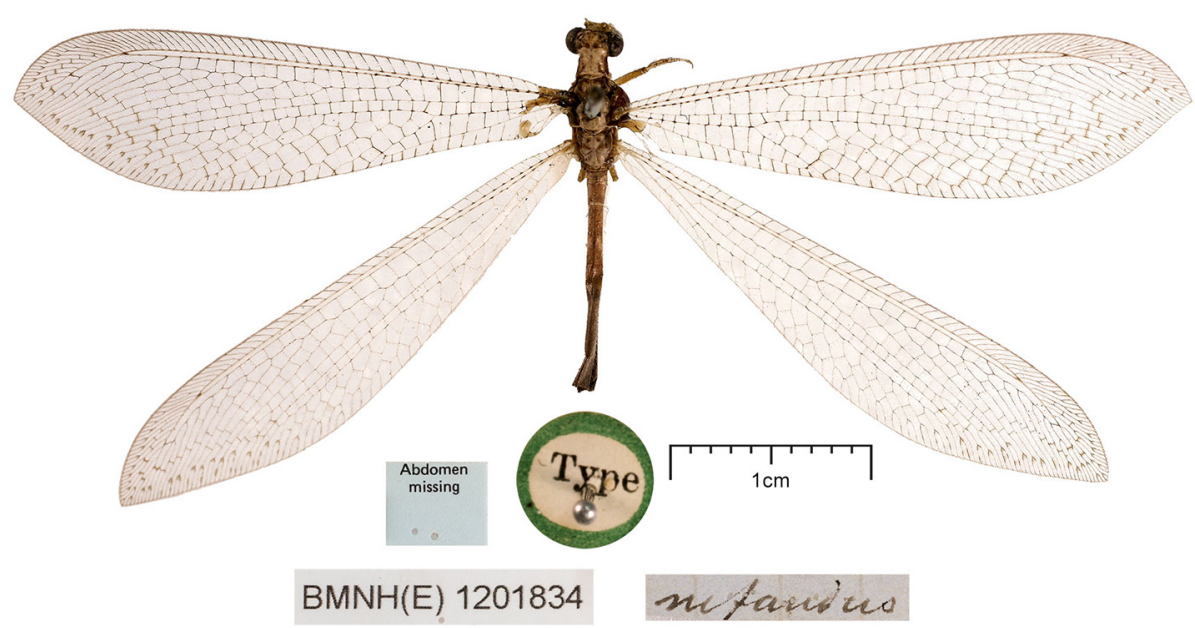

Fig. 24: Type of Myrmeleon nefandus Walker, 1853

Type of Distoleon roscidus. Checked, preserved in MNHP.

LECTOTYPE (present designation): female "/ Lectotype / Macronemurus roscidus (Navás, 1937) / design.: Ábrahám \& / Giacomino 2017 [red label] /".

Label information. "/ Type [white label in capital red letters] // Lonawla / (Bombay) / 30. X. 1934 [white label with handwriting] // Nelees / roscidus Nav. [with Navás's handwriting] / det. Navás S.J. [printed] [white label] // Muséum Paris / Login Navas legit / 10 [white label in capital letters] /".

In Navás (1937) "Gonawla, Bombay, India, 23-30.X.1934, H. Benavente S. J. leg". 


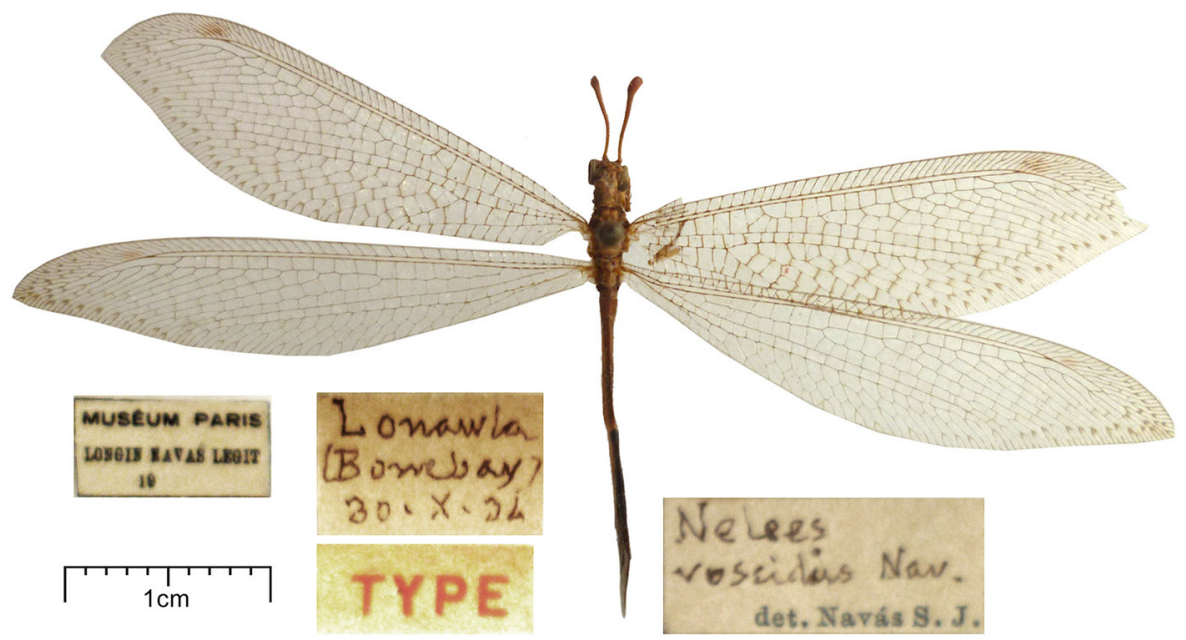

Fig. 25: Neeles roscidus Navás, 1937 n. syn. of Distoleon nefandus (Walker, 1853)

Synonymy is marked as "/ Distoleon nefandus (Walker, 1853) / syn.: Ábrahám \& / Giacomino 2017 [white label in printed letters]/"

Type condition. Good, rigth wing broken but glued.

Comment. Neuroleon (Neuroleon) roscidus (Navás, 1937) (Stange 2004) is moved to Distoleon Banks, 1910 and it is a new junior synonym of Distoleon nefandus (Walker, 1853).

Distoleon solitarius (Hölzel, 1970)

Distoleon solitarius (Hölzel, 1970): 132 (Odescr).

Syn. Distoleon symphineurus C.-k. Yang, 1986: 427 (Odescr), Wang et al. 2018 (Mon), Yang et al. 2018 (Chlist), n. syn., (Fig. 26).

Type of Distoleon symphineurus: Holotype male checked, preserved in CAUB.

Label information. "/ CAU-N / 100812 [white label] // Holotype / + [white label with red upper band] // ??????? [handwritten in Chinese] / ????? [handwritten in Chinese] / 1700m / ????? [handwritten in Chinese] [19]80. 06. 30. [white label] // ????? [handwritten in Chinese] / Distoleon / symphineurus / Yang, 1986 / Det. Jikun Yang [white label with narrow black margins] // CAU-N / 100813 [white label] // Paratype / ऽ [white label with yellow upper band] // ????? [handwritten in Chinese] / ????? [handwritten in Chinese] / 1700m / ????? [handwritten in Chinese] [19]79. 06. 22. [white label] // ????? [handwritten in Chinese] / Distoleon / symphineurus / Yang, 1986 / Det. Jikun Yang [white label with narrow black margins] /".

In YANG (1986) "Holotype ふ̂, Yunnan Prov., Dongchuan C. 1700 m, 1980-VI-30; allotype $\widehat{\delta}$, Deqen Co. 3000 m, 1979-VI-22 at light".

Type condition. Bad, both antennae missing, abdomen lost (holotype); medium, right antenna missing, tip of abdomen lost (paratype).

Comment. Distoleon symphineurus C.-k. Yang, 1986 is a new junior synonym of Distoleon solitarius (Hölzel, 1970). Holotype and paratype labels were confused in the collection and in the original description or vice versa (YANG 1986).

Distribution of Distoleon solitarius. China (Yunnan) (YANG 1986), Mongolia (HöLzEL 1970, KRIVOKHATSKY et al. 1996). 


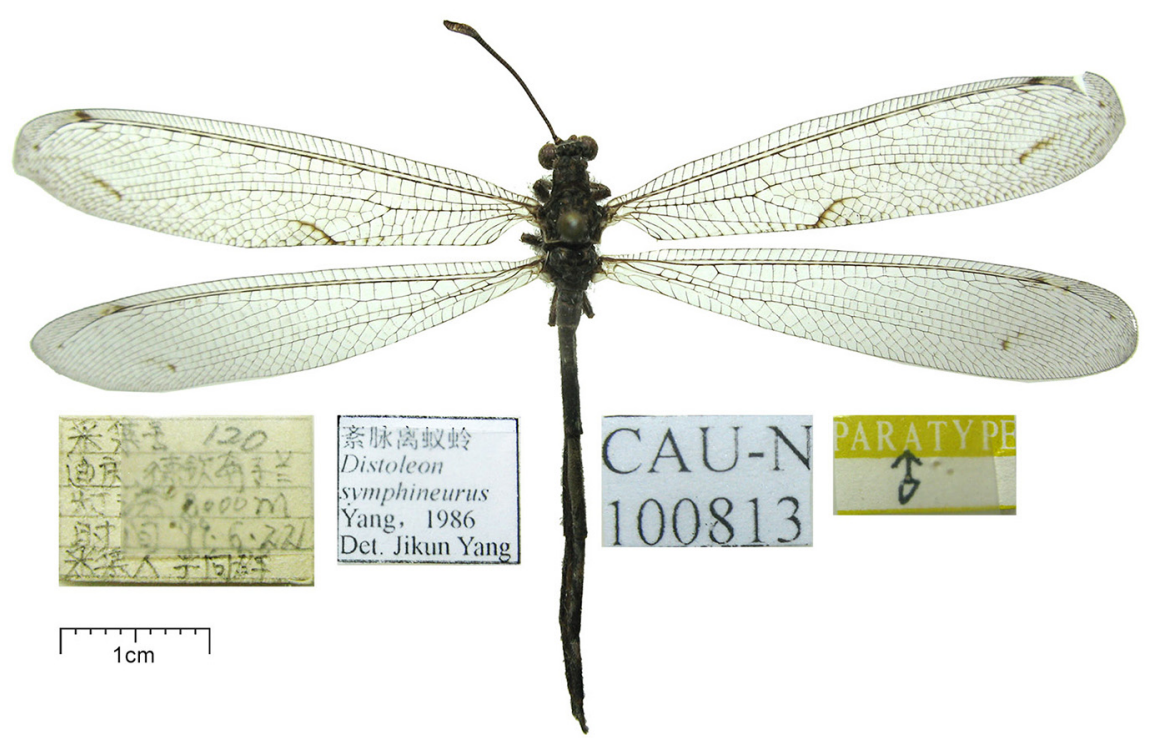

Fig. 26: Distoleon symphineurus C.-k. Yang, 1986 n. syn. of Distoleon solitarius (Hölzel, 1970)

Distoleon sylphis (Gerstaecker, 1894)

Formicaleo sylphis Gerstaecker, 1894: 137 (Odescr), (Fig. 27).

Distoleon sylphis (Gerstaecker, 1894) - Stange 2004 (Mon, Comb).

Syn. Macronemurus interruptus Kolbe, 1897: 23 (Odescr), Banks 1920 (Dist), n. syn., (Fig. 28).

Distoleon interrupta (Kolbe, 1897) - Stange 2004 (Mon, Comb).

Syn. Formicaleo turbidus Navás, 1915b: 11 (Odescr), n. syn., (Fig. 29).

Formicaleon turbidus (Navás, 1915) - Banks 1920 (Dist).

Distoleon turbidus (Navás, 1915) - Stange 2004 (Mon, Comb).

Syn. Formicaleo lambarenus Navás, 1921: 303 (Odescr), n. syn., (Fig. 30).

Distoleon lambarenus (Navás, 1921) - Stange 2004 (Mon, Comb).

Syn. Formicaleo gilsi Navás, 1933c: 311 (Odescr), n. syn., (Fig. 31).

Distoleon gilsi (Navás, 1933) - Stange 2004 (Mon).

Syn: Nelees muzanus Navás, 1922: 252 (Odescr), n. syn., (Fig. 32).

Neuroleon (Neuroleon) muzanus (Navás, 1922) - Stange 2004 (Mon, Comb).

Distoleon muzanus (Navás, 1922) - n. comb.

Type of Distoleon sylphis. Checked, preserved in EMAU.

LECTOTYPe (present designation): male "/ Lectotype / Formicaleo sylphis / Gerstaecker, 1885 / design.: Ábrahám \& / Giacomino 2019 [red label] /".

Label information. "/ sylphis / Gerst.* / Agoncho, / Gabun, Buchh. //, white label // Zool. Mus. / Greifswald / II 27432 [blue label with narrow black margins and with Gerstaecker's handwriting] /".

In Gerstaecker (1894) "Agoncho (Gabon)".

Type condition. Good, right antenna broken.

Comment. It is a valid species and four synonyms can be found as Macronemurus interruptus Kolbe, 1897, Formicaleo turbidus Navás, 1915b, Formicaleo lambarenus Navás, 1921, Formicaleo gilsi Navás, 1933.

Distribution of Distoleon sylphis. It occurs in tropical Africa: Gabon (GERSTAECKER 1894), Kenya (Kolbe 1897), Democratic Republic of the Congo (Banks 1920, Navás 1919 [1921], 1933c) and Mozambique (Navás 1922). 


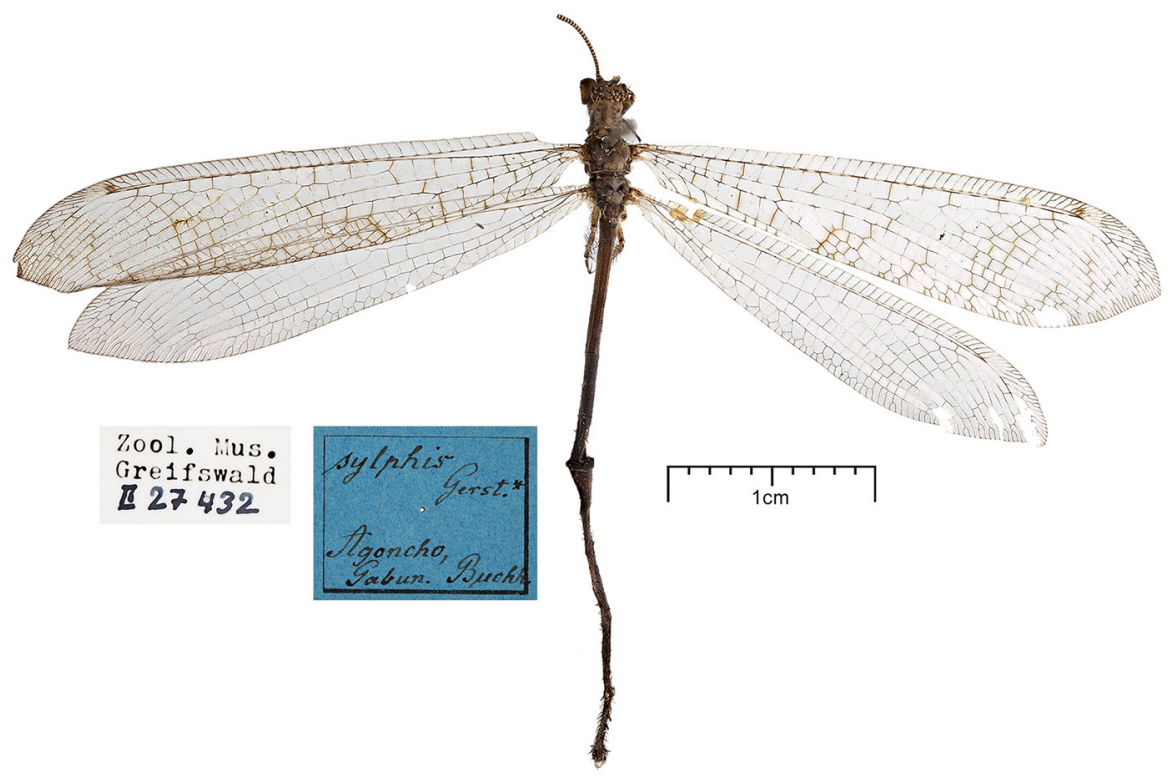

Fig. 27: Lectotype of Distoleon sylphis (Gerstaecker, 1894)

Type of Macronemurus interruptus. Checked, preserved in ZMHB.

LECTOTYPE (present designation): female "/ Lectotype / Macronemurus interruptus Kolbe, 1897 / design.: Ábrahám \& / Giacomino 2019 [red label] /".

Label information. "/ Type [red label in printed letters] // S.Albert-Njansa / Buginda / 8. VII. [18]91 / Stuhlmann S. [blue label in printed letters] // Macronemurus / interruptus / n. sp. Kolbe [white label with Kolbe's handwriting] // 55 [white label in printed numbers] // QR code/ http://coll-mfn-berlin.deudbca61 [white label in printed letters] /".

In KolBe (1897) "südlich vom Albert-Nyansa, 1 (8. Juli 1891, Stuhlmann)".

Synonymy is marked as "/ Distoleon sylphis / (Gerstaecker, 1894) / syn.: Ábrahám \& / Giacomino 2017 [white label in printed letters]/".

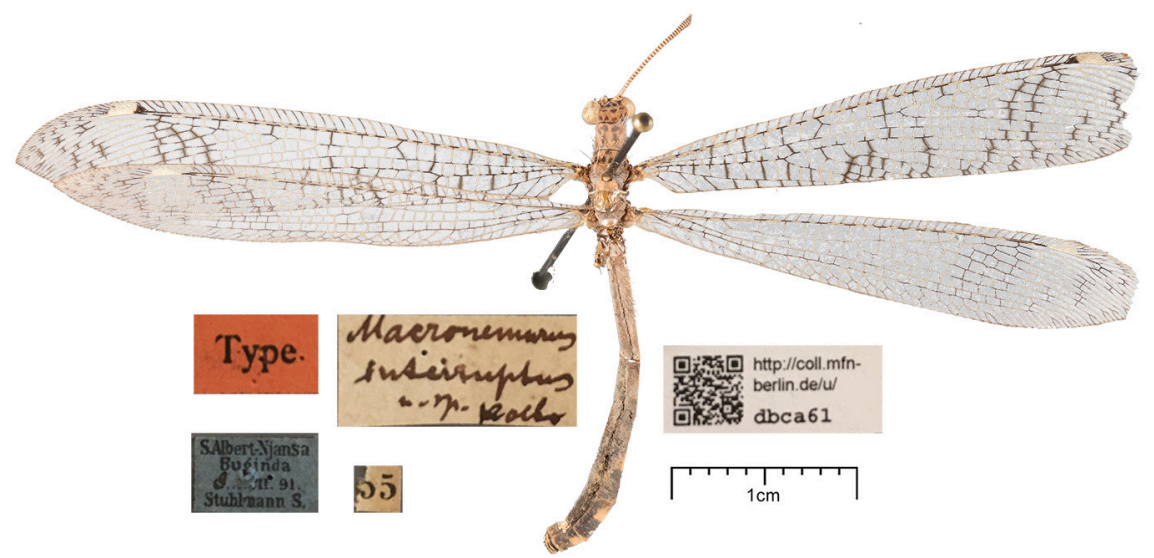

Fig. 28: Distoleon interrupta (Kolbe, 1897) n. syn. of Distoleon sylphis (Gerstaecker, 1894) 
Type condition. Good, left antenna broken and left tips of wings missing.

Comment. Distoleon interrupta (Kolbe, 1897) is a new synonym of Distoleon sylphis (Gerstaecker, 1894).

Type of Formicaleo turbidus. Checked, preserved in MNHP.

Lectotype was designated by Legrand "/ Formicaleo / turbidus Navás, 1915 / Lectotype / J. Legrand dét. 1992 [white label with Legrand's handwriting] /".

Label information. "/ Type [white label in capital letters] // Museum Paris / Congo / R. Thollon 1886 [green label] // Formicaleo / turbidus Nav. / P. Navás S.J. det. [in printed letters] [blue label with Navás's handwriting] /".

In Navás (1915) "Congo, R. Thollon, 1886".

Synonymy is marked as "/ Distoleon sylphis / (Gerstaecker, 1894) / syn.: Ábrahám \& / Giacomino 2017 [white label in printed letters]/".

Type condition. Bad, right antenna and abdomen broken and missing.

Comment. Distoleon turbidus (Navás, 1915) is a new synonym of Distoleon sylphis (Gerstaecker, 1894) .

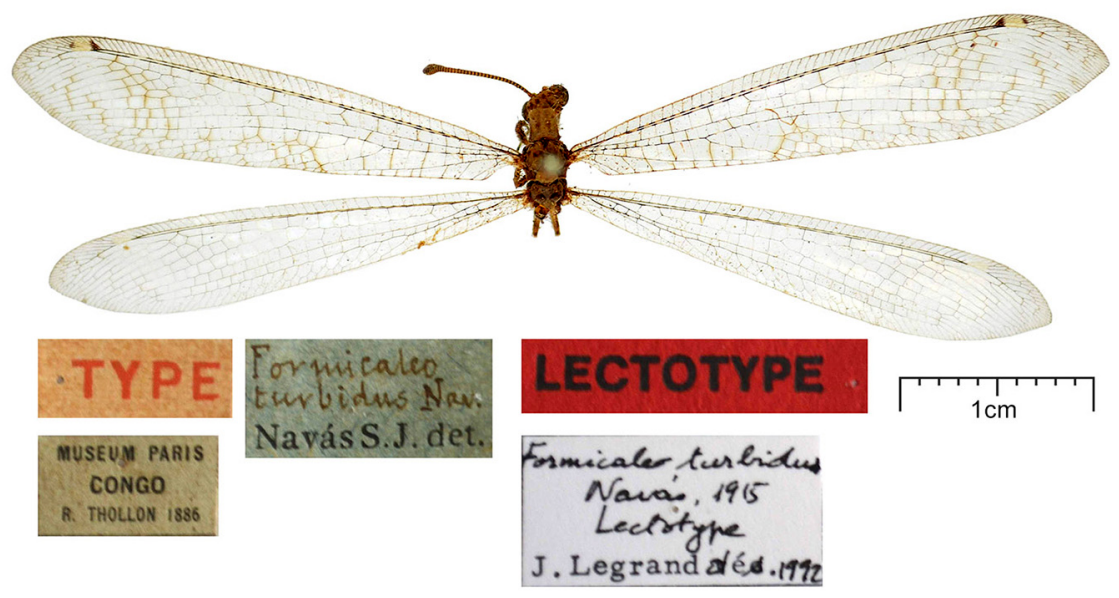

Fig. 29: Distoleon turbidus (Navás, 1915) n. syn. of Distoleon sylphis (Gerstaecker, 1894)

Type of Formicaleo lambarenus. Checked, preserved in MNHP.

Lectotype was designated by Legrand "/ Lectotype [red label in capital printed letters] / Formicaleo / lambarenus Navás, 1921 / Lectotype / J. Legrand dét. 1992 [white label with Legrand's handwriting]/".

Label information. "/ Type [white label in capital letters] // Museum Paris / Ogcoué / Lambaréné / R. Ellenberger 1912 [blue label] // Formicaleo / lambarenus Nv [with Navás's handwriting] / P. Navás S.J. det. [printed] [blue label] /".

In Navás (1919 [1921]) "Congo francés: Ogooaié, Lambaréné, R. Ellenberger, 1912". Synonymy is marked as "/ Distoleon sylphis / (Gerstaecker, 1894) / syn.: Ábrahám \& / Giacomino 2017 [white label in printed letters]/".

Type condition. Bad, right antenna and abdomen broken and missing.

Comment. Formicaleo lambarenus Navás, 1921 is a new synonym of Distoleon sylphis (Gerstaecker, 1894). 


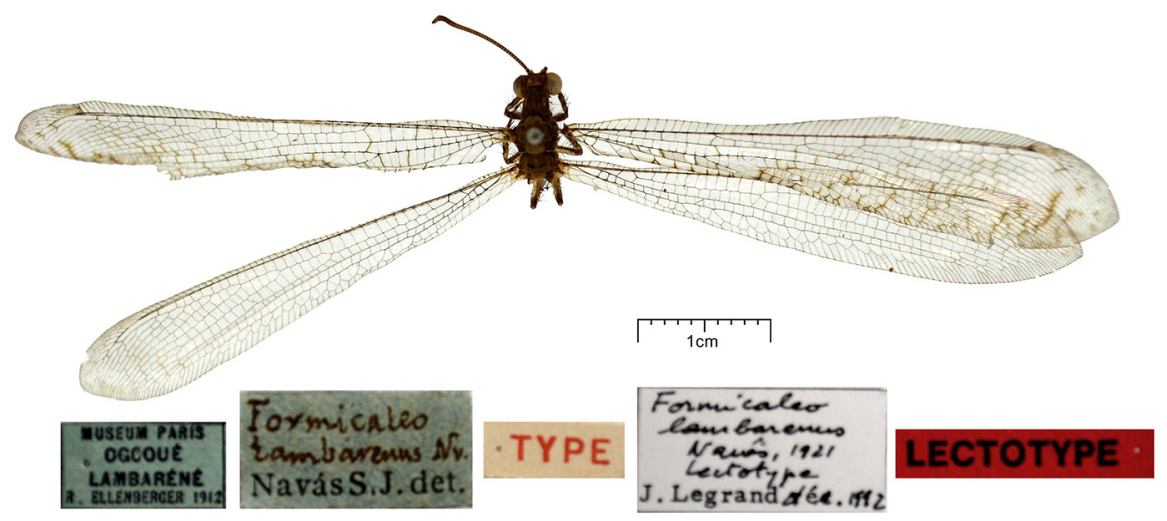

Fig. 30: Formicaleo lambarenus Navás, 1921 n. syn. of Distoleon sylphis (Gerstaecker, 1894)

Type of Distoleon gilsi. Female, checked, preserved in MRAC.

Label information. "/ Tipo [red label in capital printed letters] // Musée du Congo / Fulu sur Lua / (Ubangi), 1931, / M. Van Gils [white label] // MRAC - Tervuren / database No / MRAC00486 [white label] // Formicaleo / Gilsi Nav. [with Navás's handwriting] / P. Navás S.J. det. [printed] [blue label] // Type [red label with double margins and in capital letters] // R. dét / Y / 2426 [white label] /".
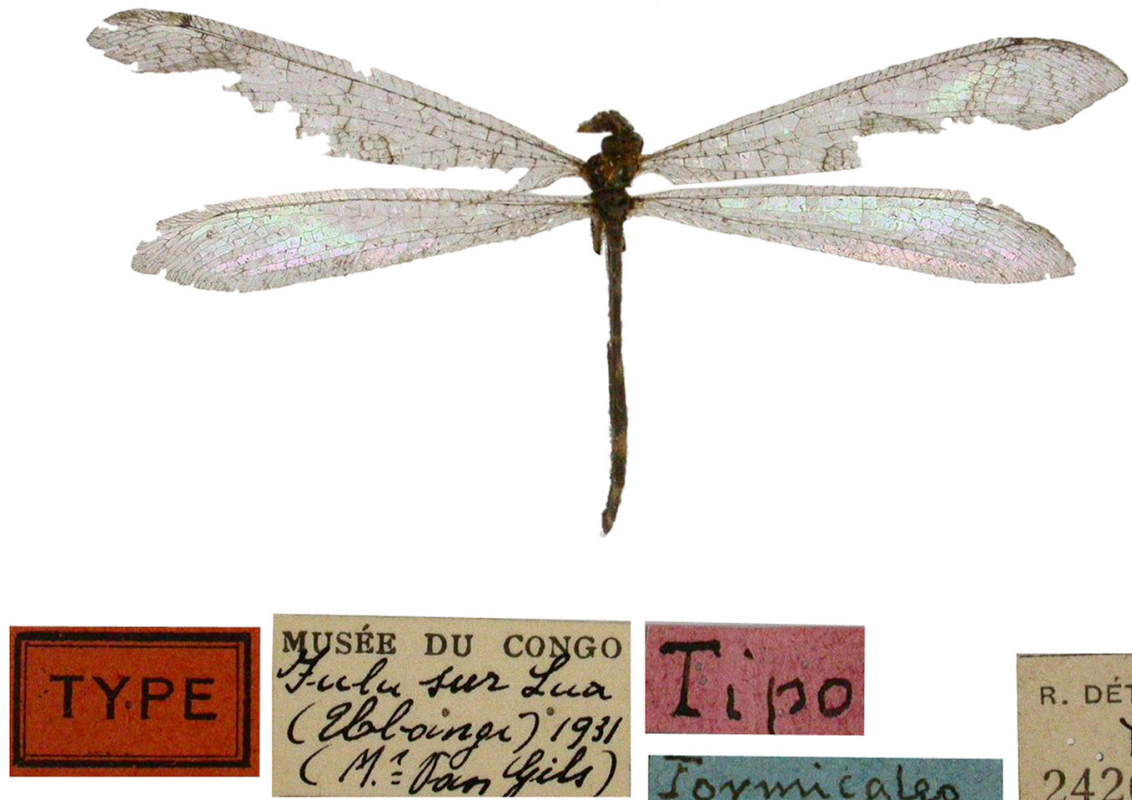

MRAC-Tervuren

Formicalao Girsi Naw.

R. DÉT.

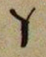

2426

Database $\mathrm{No}_{0}$

C) Royal Museumfor Centrall Africa, 'Belgium

Fig. 31: Formicaleo gilsi Navás, 1933 n. syn. of Distoleon sylphis (Gerstaecker, 1894) 
In NAvÁs (1933c) "Fulu sur Lua (Ubangi), 1931, M. Van Gils".

Type condition. Bad, antenna broken, head and wings strongly damaged.

Comment. Formicaleo gilsi Navás, 1933 is a new synonym of Distoleon sylphis (Gerstaecker, 1894).

Type of Neeles muzanus: Checked, preserved in MNHP.

Lectotype was designated by Legrand "/ Lectotype [red label in capital letters] // Neeles muzanus / Navás, 1922 / Lectotype / J. Legrand det. 1992 [white label with Legrand's handwritting]/".

Label information. "/ Type [white label in capital letters] // Museum Paris / Bassin Inf. du Zambèze / Vallée du Muza / 32 $2^{\circ}$ long. E., $18^{\circ}$ lat. S. / (DE 1000 A 1120 D’alt.) / G. Vasse 1905 [blue label] // Neeles / muzanus Nav. [with Navás's handwriting] / Navás S.J. det. [printed] [blue label] /".

In Navás (1922) "Afrique. Bassin inf. du Zambèze, Vallée du Muza, 32º long. E. $18^{\circ}$ lat. S. (De 1000 à 1120 m. d'altit.), G. Vasse, 1905" (Mus. de Paris)".

Synonymy is marked as "/ Distoleon sylphis / (Gerstaecker, 1894) / syn.: Ábrahám \& / Giacomino 2017 [white label in printed letters]/".

Type condition. Medium antenna missing, wings broken but glued.

Comment. Neuroleon (Neuroleon) muzanus (Navás, 1922) (StANGE 2004) is moved to Distoleon Banks, 1910 and it is a new synonym of Distoleon sylphis (Gerstaecker, 1894).

Distoleon tholloni Navás, 1914

Formicaleo tholloni Navás, 1914b: 105 (Odescr), (Fig. 34).

Distoleon tholloni (Navás, 1914) - Stange 2004 (Mon, Comb).

Syn. Feina languida Navás, 1931: 264 (Odescr), n. syn., (Fig. 35).

Distoleon languida (Navás, 1931) - Stange 2004 (Mon, Comb).

Distoleon languidus (Navás, 1931) - Oswald 2019 (Nom).

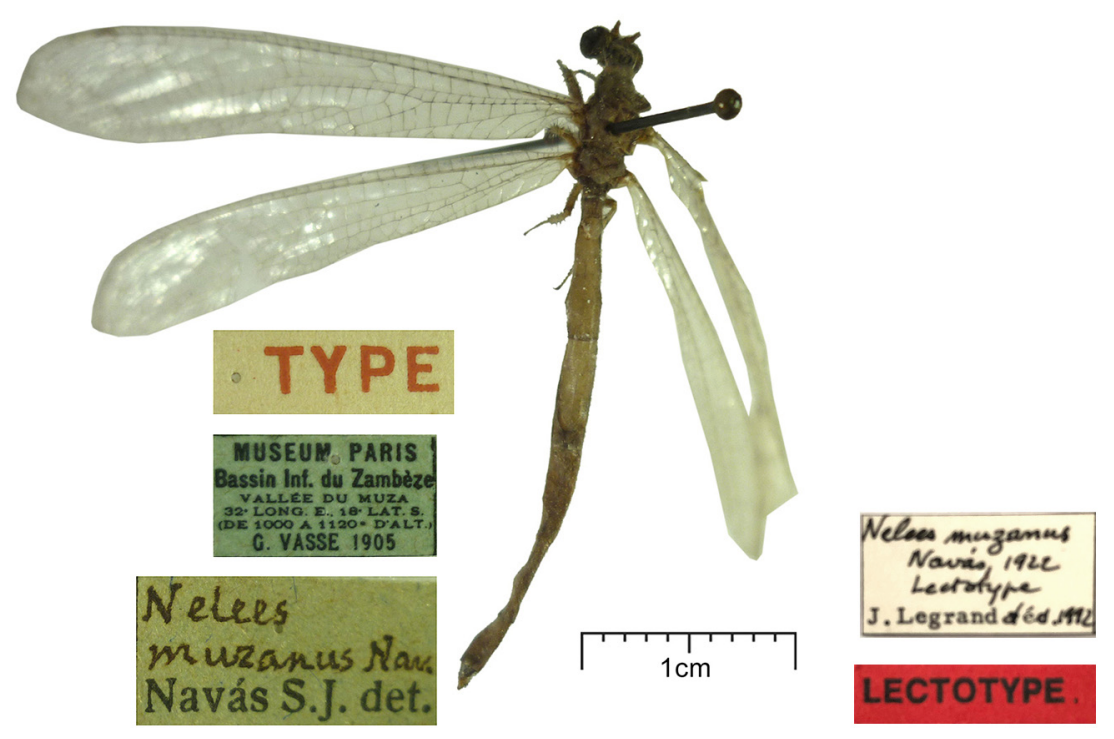

Fig. 32: Neeles muzanus Navás, 1922 n. syn. of Distoleon sylphis (Gerstaecker, 1894) 
Type of Distoleon tholloni. Checked, preserved in MNHP.

Lectotype male was designated by Legrand "/ Lectotype [red label in capital printed letters] // Formicaleo tholloni / Navás, 1914 / Lectotype / J. Legrand dét. 1992 [white label with Legrand's handwriting] /".

Label information. "/ Type [white label in capital letters] // 1108686 [white round shaped label] // Museum Paris / Congo / R. Thollon 1886 [blue label] // Formicaleo / Tholloni Nav. [with Navás's handwriting] / P. Navás S.J. det. [printed] [blue label] /".

In Navás (1914b) "Congo, Thollon, 1886".

Type condition. Good, antennae missing.

Comment. It is a valid species.

Distribution of Distoleon tholloni. It occurs in tropical Africa: Ivory Coast, Democratic Republic of the Congo (NAvás 1914b).

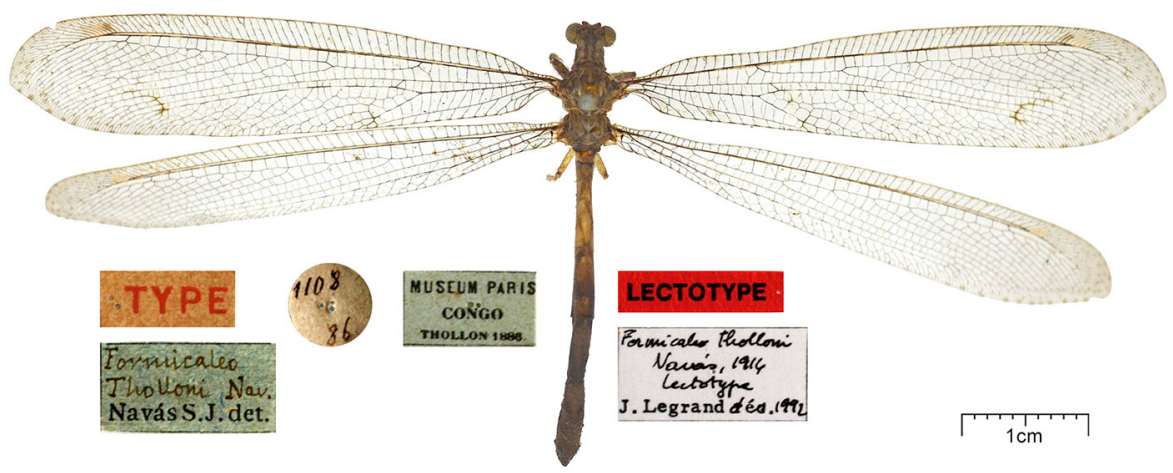

Fig. 33: Lectotype of Distoleon tholloni (Navás, 1914)

Type of Distoleon languidus. Checked, preserved in MRAC.

Label information. "/ Holotype [red label with double black margins and in capital letters] // Typus [red label with handwritting] // Musée du Congo / Katanga Kafakumba / 23-V-[19]25 / F. G. Overleat [white label] // MRAC - Tervuren / database No / MRAC00545 [blue label] // Feina / languida Nav. [with Navás's handwriting] / P. Navás S.J. det. [printed] [blue label] // Kafakumba / 23. V. [19]25 / G. F. Overleat [blue label with handwritting] // R. dét / 1751 / v [white label with black margins] /".

In NavÁs (1931) "ㅇ / Kafakumba, 23-V-1925 (G. F. Overlaet)".

Type condition. Good, only antenna missing.

Comment. Distoleon languidus (Navás, 1931) is a new junior synonym of Distoleon tholloni (Navás, 1914). Earlier, STANGe (2004) has already synonymed Dolicholeon ghesquierinus Navás, 1932 to Distoleon languidus (Navás, 1931) which we also confirm.

Geyria lepidula (Navás, 1912)

Geyria lepidula (Navás, 1912b): 748 (Odescr).

Syn. Neuroleon parvissimus Fraser, 1952: 481 (Odescr), n. syn., (Fig. 35).

Geyria parvissima (Fraser, 1952) - Stange 2004 (Mon, Comb). 


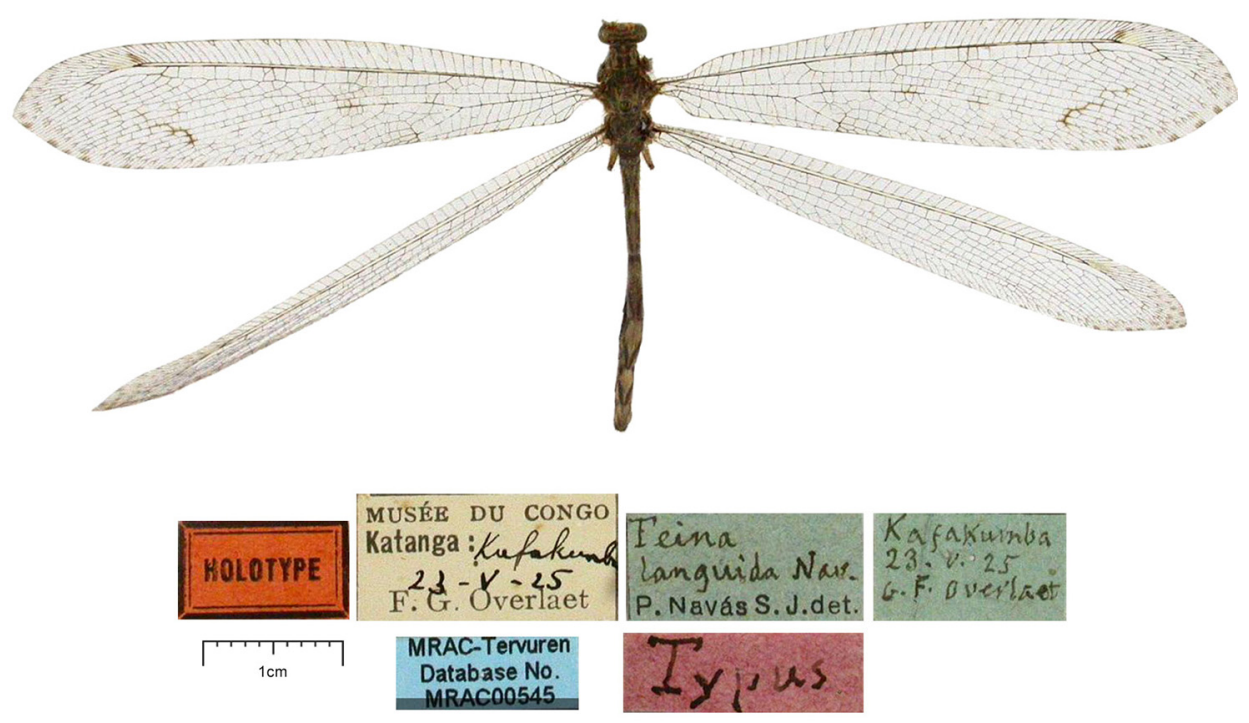

Fig. 34: Feina languida Navás, 1931 n. syn. of Distoleon tholloni (Navás, 1914)

Type of Neuroleon parvissimus. Checked, preserved in MNHP.

LECTOTYPE (present designation): male "/ Lectotype / Neuroleon parvissimus Fraser, 1952 / design.: Ábrahám \& / Giacomino 2017 [red label] /".

Label information. "/ Type [red label in capital letters] // Mauretanie / Arjoril. 1948 / L. Berland et A. Villiers rec. [blue label] // Neuroleon ô / parvissimus / Fraser, 1952 //, blue label // Museum Paris [blue label] /".

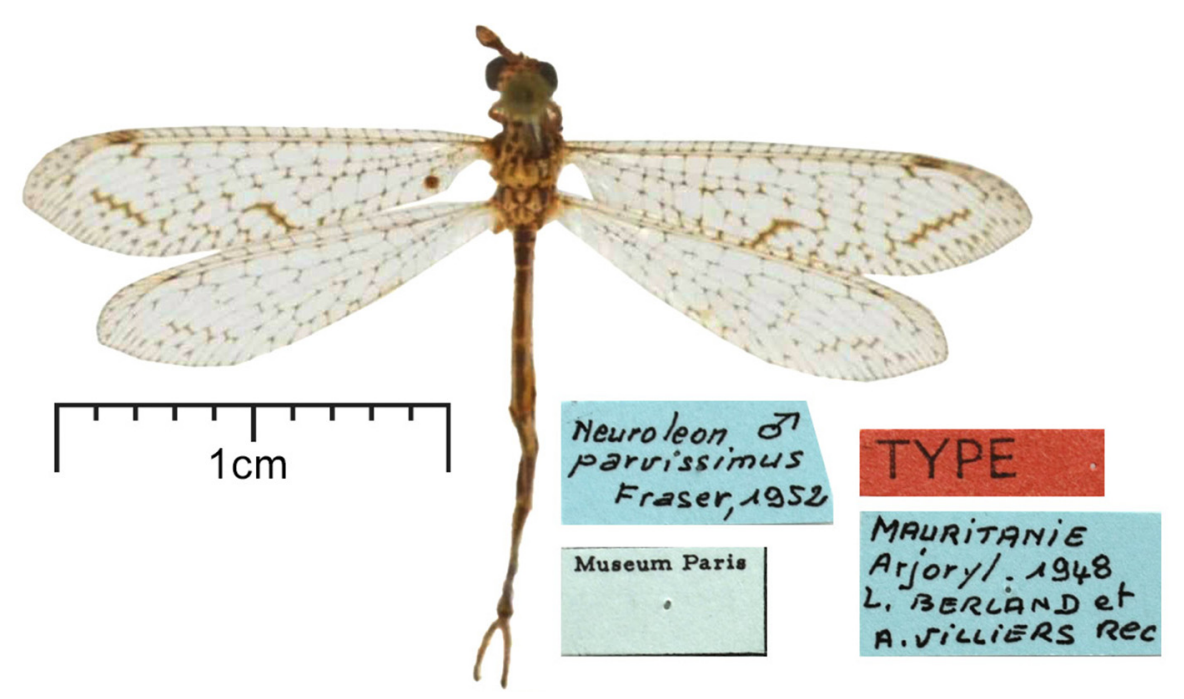

Fig. 35: Neuroleon parvissimus Fraser, 1952 n. syn. of Geyria lepidula (Navás, 1912) 
In Fraser (1952) "Akjoujt (Mauretania), 28-X-[19]48 (coll. L. Berland and A. Villiers)".

Synonymy is marked as "/ Geyria lepidula / (Navás, 1912) / syn.: Ábrahám \& / Giacomino 2017 [white label in printed letters]/".

Type condition. Excellent, left antenna missing.

Comment. Geyria parvissima (Fraser, 1952) is a new synonym of Geyria lepidula (Navás, 1912) .

Distribution of Geyria lepidula. A common and a widespread species, known in the Saharan zone from Morocco via Israel to the Arabian Peninsula (AsPöcK et al. 2001). Its area expands to SW Asia: Iran (HöLzel 1987), Pakistan (ÁBRAHÁm 2017) and NW India (Rajasthan) (GHosH 1981).

Macronemurus appendiculatus (Latreille, 1807)

Macronemurus appendiculatus (Latreille, 1807): 193 (Odescr).

Syn. Formicaleo dumontinus Navás, 1933b: (Odescr), n. syn., (Fig. 36).

Distoleon dumontinus (Navás, 1933b) - Aspöck \& Hölzel 1996 (Comb, Chlist), Aspöck et al. 2001 (Mon).

Macronemurus dumontinus (Navás, 1933b) - n. comb.

Type of Formicaleo dumontinus. Checked, preserved in MNHP.

Lectotype female was designated by Legrand "/ Lectotype [red label in capital letters] / Formicaleo / dumontinus Navás, 1933 / Lectotype / J. Legrand dét. 1992 [white label with Legrand's handwriting]/".

Label information. "/ Museum Paris / Tunisie / Maknassy, C. Dumont, 1927 [blue label] // Juin [white label with narrow balck frame] // Type [white label in capital red letters] // Formicaleo / dumontinus Nav. [blue label with Navás's handwriting] / P. Navás S.J. det. [in printed letters] /".

In NavÁs (1933b) "Tunisie: Maknassy, C. Dumont, 1927, Juin".

Synonymy is marked as "/ Macronemurus appendiculatus / (Latreille, 1807) / syn.: Ábrahám \& / Giacomino 2017 [white label in printed letters]/".

Type condition. Good, both antennae missing.

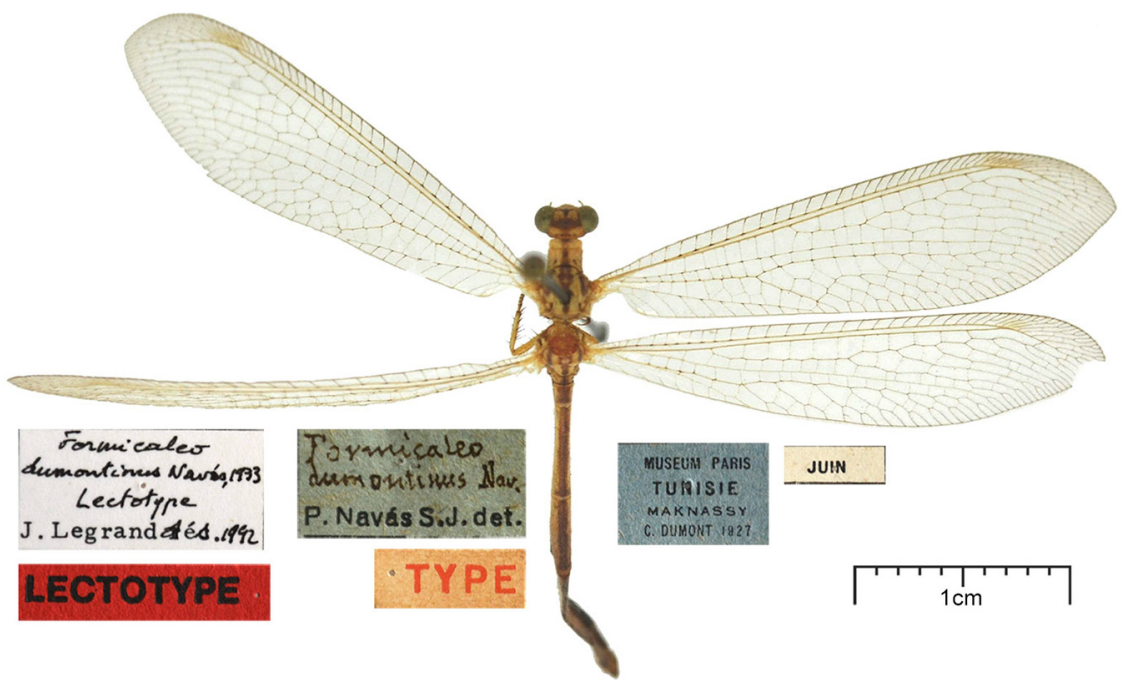

Fig. 36: Formicaleo dumontinus Navás, 1933 n. syn. of Macronemurus appendiculatus (Latreille, 1807) 
Comment. Distoleon dumontinus (Navás, 1933b) (AsPöck \& Hölzel 1996) is moved to Macronemurus A. Costa, 1855 and it is a new junior synonym of Macronemurus appendiculatus (Latreille, 1807) .AsPöck et al. (2001) treated it as a nomen dubium because the type specimen was presumed to have been lost before. STANGE (2004) checked the type but he did not synonymed it.

Distribution of Macronemurus appendiculatus. Its distribution is still not clear, it is a common species in SW Europe and North Africa. The faunistical data are uncertain in Central Europe (Slovakia) (LETARDI et al. 2018). Earliar, its occurrence in Greece (STEIN 1863) seemed to be uncertain in the Balkan Peninsula but it was recently confirmed by DEVETAK et al. (2013) in Albania. Its occurrence is also uncertain in Asia: Lebanon, Israel, Turkey (HöLzel 1987, AspöcK et al. 2001, CAMBUlat 2007), Egypt (Sinai) and Palestine (now Israel) (NAvÁs 1926b, Bodenheimer 1937).

Macronemurus loranthe Banks, 1911

Macronemurus loranthe Banks, 1911: 25 (Odescr).

Syn. Macronemurus schoutedeni Navás, 1930a: 305 (Odescr), Stange 2004 (Mon), n. syn., (Fig. 37 ).

Type of Macronemurus schoutedeni. Male, checked, preserved in MRAC.

Label information. "/ Type [red label with double margins and in capital printed letters] / Typus [red label with handwriting] // Musée du Congo / Haut-Uele: Oka/ 2-V1925 / Dr. H. Schouteden [white label] // Formicaleo / schoutedeni Nav. [with Navás's handwriting] / P. Navás S.J. det. [printed] [blue label] // MRAC - Tervuren / database No / MRAC00487 [blue label] // R. dét / S / 1474 [white label] /".

In NAvÁs (1930) "Ituri: Mahagi".

Type condition. Good, antennae missing.

Comment. Macronemurus schoutedeni Navás, 1930 is a new junior synonym of Macronemurus loranthe Banks, 1911.

Distribution of Macronemurus loranthe. It may occur in tropical and subtropical Africa: Mali (Michel \& Letourmy 2007), Togo (BANKs 1911), Democratic Republic of the Congo (NAvÁs 1930a).

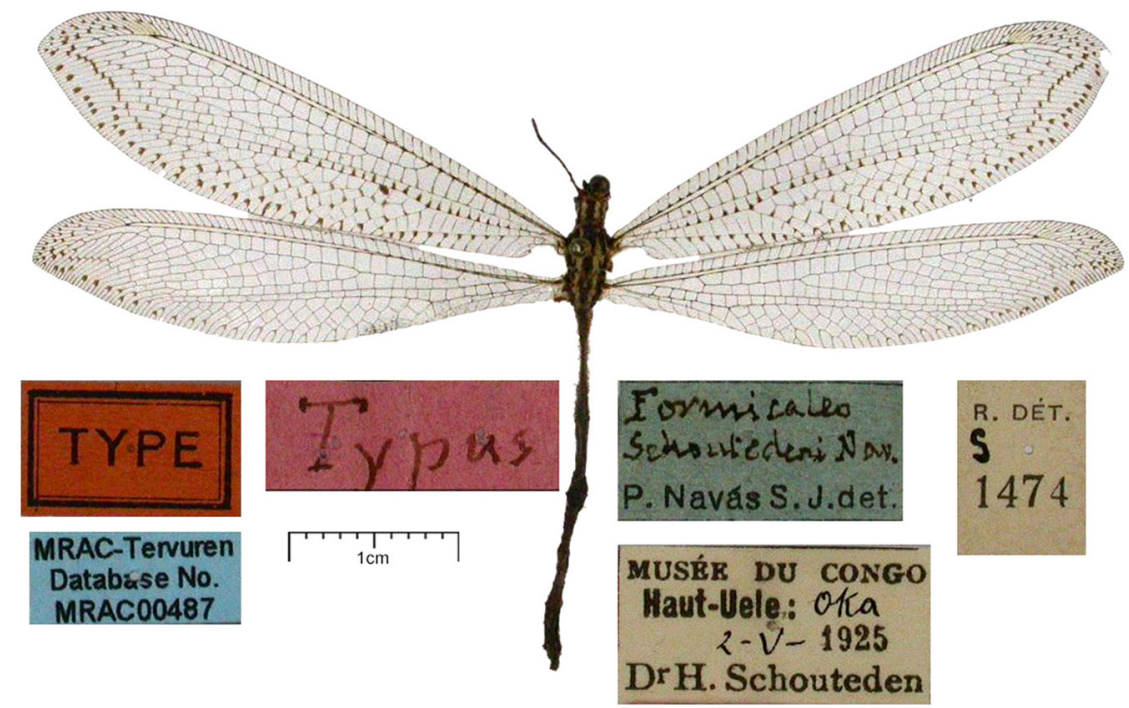

Fig. 37: Macronemurus schoutedeni Navás, 1930 n. syn. of Macronemurus loranthe Banks, 1911 
Macronemurus melanthe Banks, 1911

Macronemurus melanthe Banks, 1911: 24 (Odescr).

Syn. Macronemurus jejunus Navás, 1912a: 74 (Odescr), Stange 2004 (Mon), n. syn., (Fig. 38).

Type of Macronemurus jejunus. Male checked, preserved in MNHP.

Label information. White label in capital red letters // Type //, white label with Navás's handwriting // Macronemurus / jejunus $\widehat{\delta} / \mathrm{Nav}$./, blue label in printed letters // Museum Paris / Haut-Dahomey, de Djoujou-Kouandé, Lieut Brot 1908 //, red label in capital letters // Lectotype //, white label with Legrand's handwriting // Macronemurus jejunus / Navás, 1912 / Lectotype / J. Legrand dét. 1912 //. In Navís (1912a) “Alto Dahomey, Djoujou-Kouandé, Brot leg., 1908".

Type condition. Medium, antennae and rigth hindwing missing.

Comment. Macronemurus jejunus Navás, 1912 is a new junior synonym of Macronemurus melanthe Banks, 1911.

Distribution of Macronemurus melanthe. Known in tropical central Africa: Benin, Togo (BANKs 1911, NAvÁs 1912a).

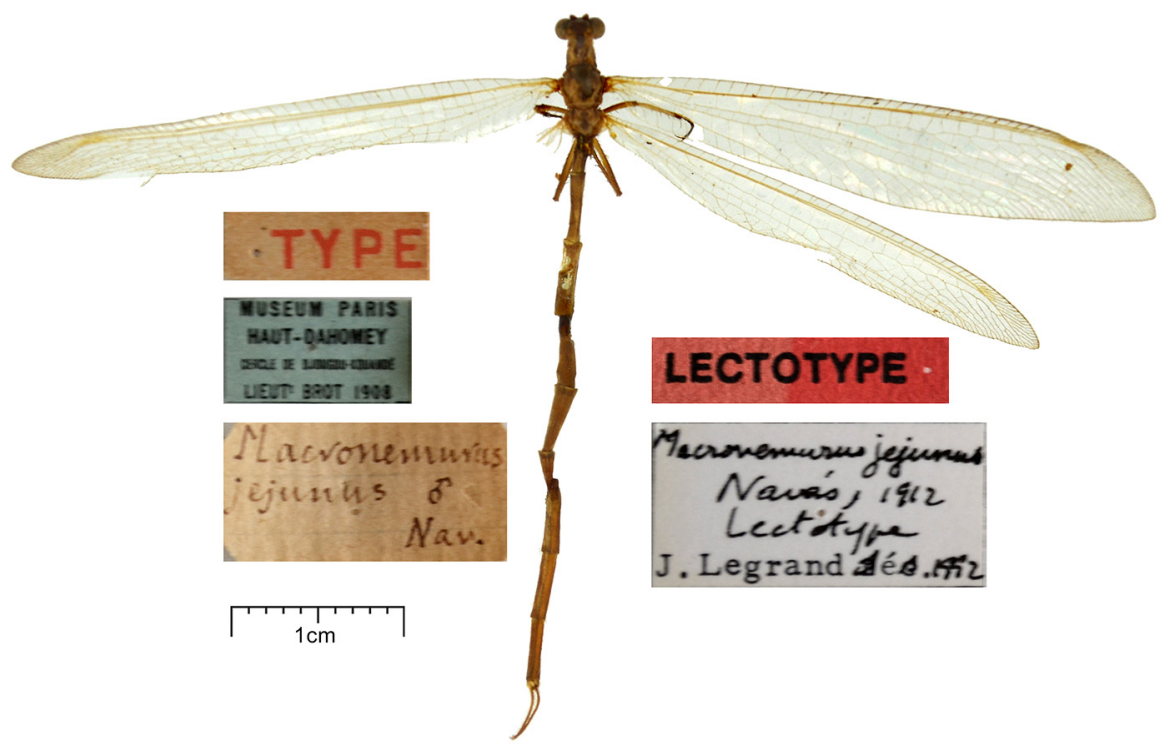

Fig. 38: Macronemurus jejunus Navás, 1912 n. syn. of Macronemurus melanthe Banks, 1911

Macronemurus perlatus (Gerstaecker, 1885)

Formicaleo perlatus Gerstaecker, 1885: 14 (Odescr) (Fig. 39).

Distoleon perlatus (Gerstaecker, 1885) - Whittington 2002 (Comb, Dist).

Macronemurus perlatus (Gerstaecker, 1885) - Esben-Petersen 1928a (Comb, Dist), 1928b (Dist), Stange, 2004 (Mon).

Syn. Macronemurus ianthe Banks, 1911: 25 (Odescr), Stange, 2004 (Mon), n. syn., (Fig. 40).

Syn. Macronemurus nuncius Navás, 1913a: 270 (Odescr), Stange, 2004 (Mon), n. syn., (Fig. 41).

Syn. Formicoleo fictus Navás, 1913a: 270 (Odescr), n. syn., (Fig. 42).

Macronemurus fictus (Navás, 1913) - Stange, 2004 (Mon).

Syn. Formicaleo neavinus Navás, 1913c: 491 (Odescr), n. syn., (Fig. in Trauber et al. 2019).

Distoleon neavinus (Navás, 1913) - Stange 2004 (Comb, Mon), Tauber et al. 2019 (Tax).

Macronemurus neavinus (Navás, 1913) - n. comb.

Syn. Macronemurus wittei Navás, 1932: 272 (Odescr), 1936a (Dist), Stange 2004 (Mon), n. syn., (Fig. 43). 
Type of Macronemurus perlatus. Checked, preserved in EMAU.

LECTOTYPE (present designation). female "/ Lectotype / Formicaleo perlatus / Gerstaecker, 1885 / design.: Ảbrahám \& / Giacomino 2019 [red label] /".

Label information. "/ perlatus / Gerst* / Transvaal Stdgr. [Staudinger] [blue label with narrow black margins and with Gerstaecker's handwriting] // Zool. Mus. / Greifswald / II 27429 [white label] /".

In Gerstaecker (1884) “Transvaal”.

Type condition. Medium, antenna missing, abdomen broken but glued it back.

Comment. Otto Staudinger, German lepidopterolgist who was a contemporary entomologist with Gerstaecker and bought many exotic materials from Asia and Africa then posted the specimens to different experts among others to Gerstaecker. Macronemurus ianthe Banks, 1911, Macronemurus nuncius Navás, 1913, Macronemurus neavinus Navás, 1913, Macronemurus wittei Navás, 1932 and Macronemurus fictus (Navás, 1913) are new synonyms of Macronemurus perlatus (Gerstaecker, 1885).

Distribution of Macronemurus perlatus. Namibia (ESBEN-PETERSEN 1928a, MANSELL 2000), Ethiopia (Esben-Petersen 1928b), Republic of South Africa (NAvÁs 1913a, http://www.africamuseum.be, det: Mansell), Kenya (NAvÁs 1914a), Zimbabwe (Whittington 2002), Angola (NAvís 1912a), Mozambique, Tanzania, Uganda (BAnks 1911, OSWALD 2019).

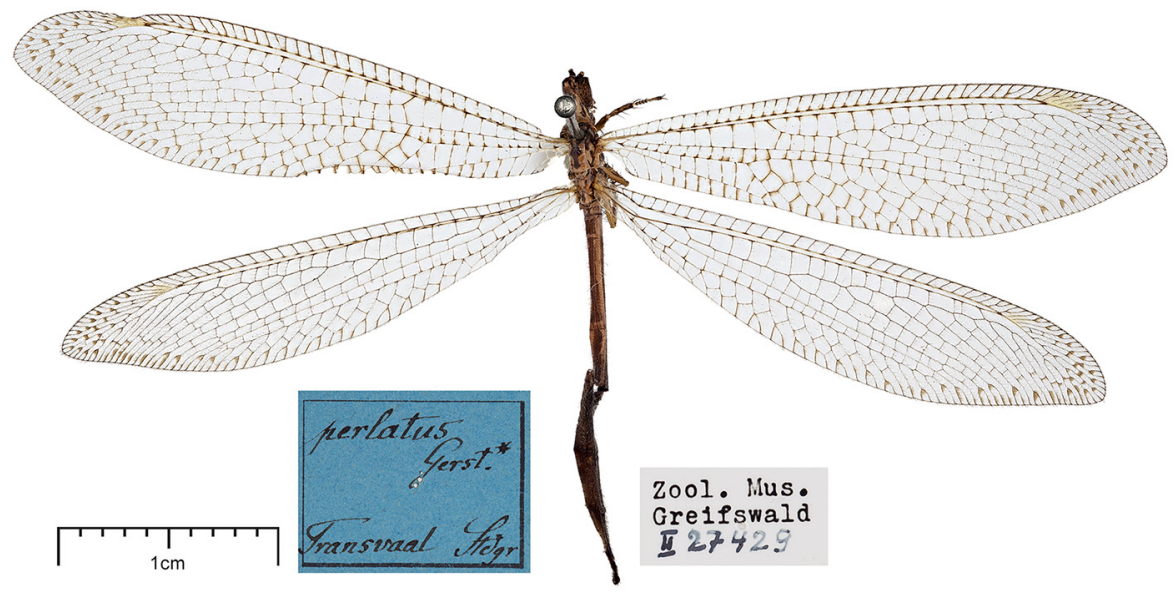

Fig. 39: Lectotype of Formicaleo perlatus Gerstaecker, 1885

Type of Macronemurus ianthe. Checked, preserved in ZMHB.

LECTOTYPE (present designation): "/ Lectotype / Macronemurus inanthe Banks, 1911 / design.: Ábrahám \& / Giacomino 2019 [red label] /".

Label information. "/ Type [red label in printed letters] // D. O. Afrika Lan- / genburg 15.-17. / V. [18]99. Dr. Fülleborn [blue label with handwriting] // Macronemurus / ianthe / type Bks [white label with double red margins and with Banks's handwriting] // QR code / http://coll-mfn-berlin.deudbca7f [white label in printed letters] /".

In BANKs (1911) "Langenburg, D. O. Afrika".

Type condition. Medium, tip of fore and hindwings broken.

Comment. Macronemurus ianthe Banks, 1911 is a new synonym of Macronemurus perlatus (Gerstaecker, 1885). 


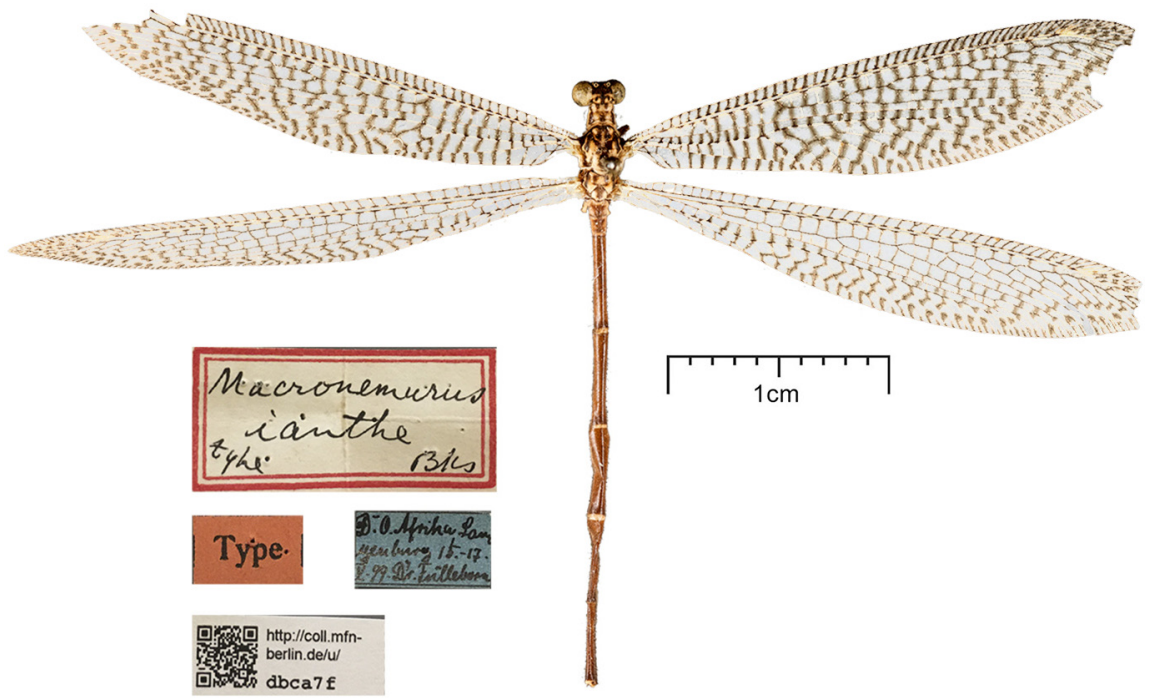

Fig. 40: Macronemurus ianthe Banks, 1911 n. syn. of Macronemurus perlatus (Gerstaecker, 1885)

Type of Macronemurus nuncius. Checked, preserved in BMNH.

LECTOTYPE (present designation): male "/ Lectotype / Macronemurus nuncius Navás, 1913 / design.: Ábrahám \& / Giacomino 2019 [red label] /".

Label information. "/ Type / H.T [round shaped white label with red margin] // Typus [red label with Navás's handwriting] // Barberton / (P. Rendall) [white label] // Distant coll. / 1911 - 383. [white label ] // Macronemurus / nuncius Nav. [with Navás's handwriting] / Navás S.J. det. [printed] [white label] // QR code / BMNH(E) / 1253367 [white label] /".

In Navís (1913a) "Barberton, P. Rendall".

Synonymy is marked as "/ Macronemurus perlatus / (Gerstaecker, 1885) / syn.: Ábrahám \& / Giacomino 2019 [white label in printed letters]/".

Type condition. Good, left forewing deformed.

Comment. Macronemurus nuncius Navás, 1913 is a new synonym of Macronemurus perlatus (Gerstaecker, 1885). There has not been any information of the species since the description (NAvás 1913a).

Type of Macronemurus fictus. Checked, preserved in BMNH.

LECTOTYPE (present designation): female "/ Lectotype / Formicoleo fictus Navás, 1913 / design.: Ábrahám \& / Giacomino 2019 [red label] /".

Label information. "/ Type / H.T [round shaped white label with red margin] // Typus [red label with Navás's handwriting] // Pretoria / (W. L. D.) [white label] // Distant coll. / 1911 - 383. [white label] // Formicoleo fictus Nav. [with Navás's handwriting] / Navás S.J. det. [printed] [white label] // QR code / BMNH(E) / 1253368 [white label in printed letters] /".

In NAvís (1913a) "Pretoria W. L. D".

Synonymy is marked as "/ Macronemurus perlatus / (Gerstaecker, 1885) / syn.: Ábrahám \& / Giacomino 2019 [white label in printed letters]/". 


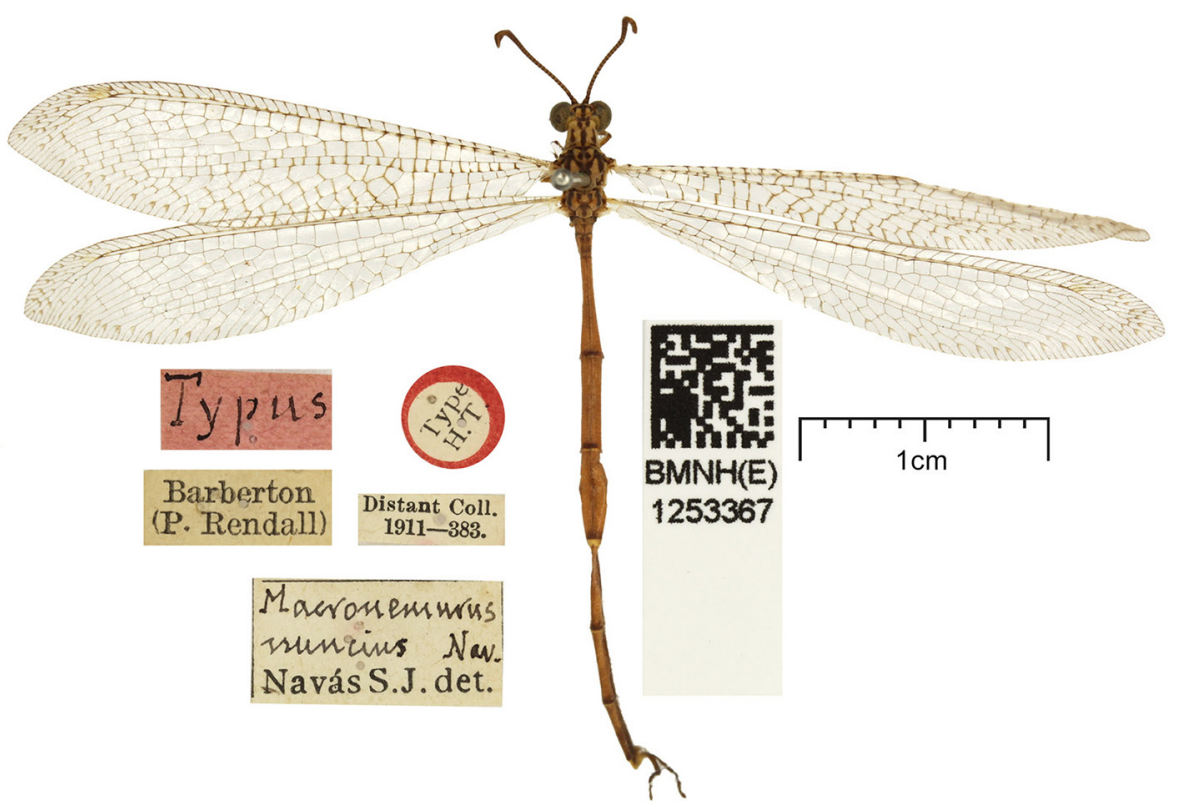

Fig. 41: Macronemurus nuncius Navás, 1913 n. syn. of Macronemurus perlatus (Gerstaecker, 1885)

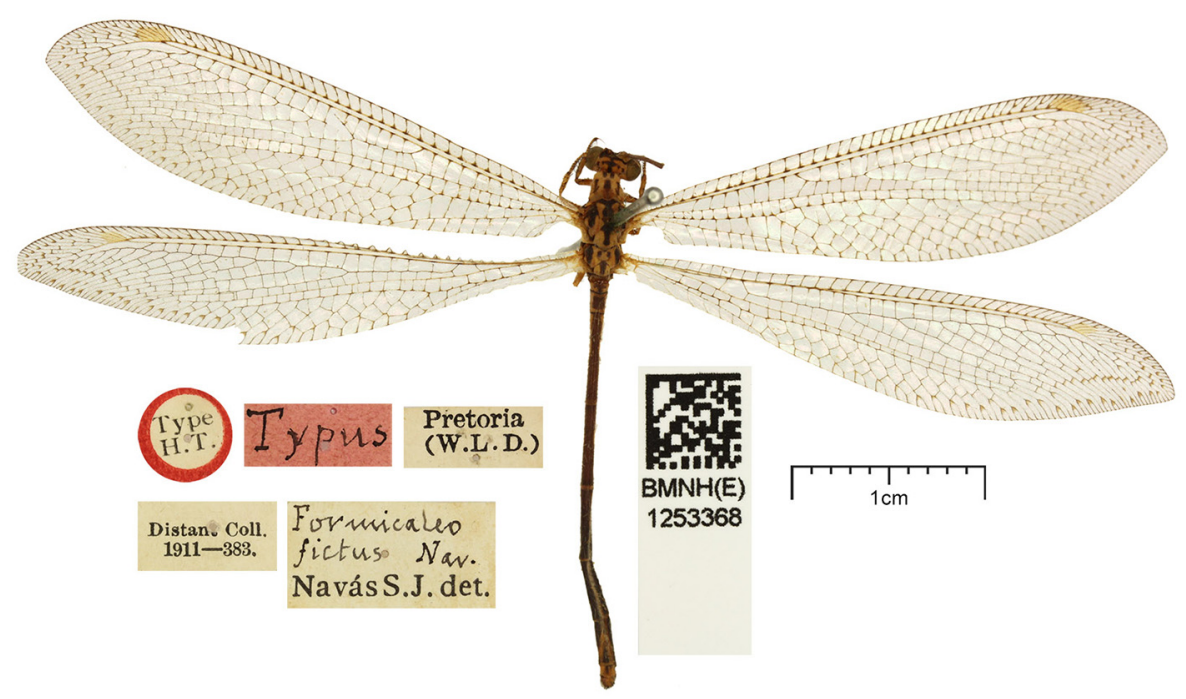

Fig. 42: Macronemurus fictus (Navás, 1913) n. syn. of Macronemurus perlatus (Gerstaecker, 1885) 
Type condition. Good, left antenna missing.

Comment. Macronemurus fictus Navás, 1913 is a new synonym of Macronemurus perlatus (Gerstaecker, 1885). There has not been any information on the species since the description (NAVÁs 1913a).

Type of Macronemurus neavinus. Sex undetermined, checked, preserved in OXUM.

Label information. Lectotype is designated by TAUBER et al. (2019) "/ Typus [red label with handwriting] // Formicaleo / neavinus / Nav. [with Navás's handwriting] / P. Navás S.J. det. [printed] [white label] / [2x] / N. E. Rhodesia, [in capital letters] / Fort Jameson / (3800 ft) / Capt.1.iv.1904. / by S.A.Neave. / Pres' 06 by him / and B.S.A. Co. [white label in printed letters] // Type [printed] Neur: No 68 / Formicaleo / neavinus / Navas/ [handwritten] / Hope Dept.Oxford [printed] [white label with narrow black margins] /".

In Navís (1913c) "N. E. Rhodesia, Fort Jameson 3800 ft, 1-IV-1904, S. A. Neave".

Synonymy is marked as "/ Macronemurus perlatus / (Gerstaecker, 1885) / syn.: Ábrahám \& / Giacomino 2019 [white label in printed letters]/".

Type condition. Medium, distal part of abdomen missing.

Comment. Based on the length of body in the original description (Navís 1913c), the gender might be female. Distoleon neavinus (Navás, 1913) (STAnge 2004) is moved to Macronemurus A. Costa, 1855 and it is a new junior synonym of Macronemurus perlatus (Gerstaecker, 1885). Only the type is known from Zimbabwe (Rhodesia) (NAvÁs 1913c). TAUBER et al. (2019) figured the type specimen.

Type of Macronemurus wittei. Male, checked, preserved in MRAC.

Label information. "/ Typus [red label with handwriting] // Type [red label with double margins and in capital printed letters] // Musée du Congo [printed] / Kiambi / 24-IV[19]31. / G. F. de Witte [handwritten] [white label] // Macronemurus / Wittei Nav. [with

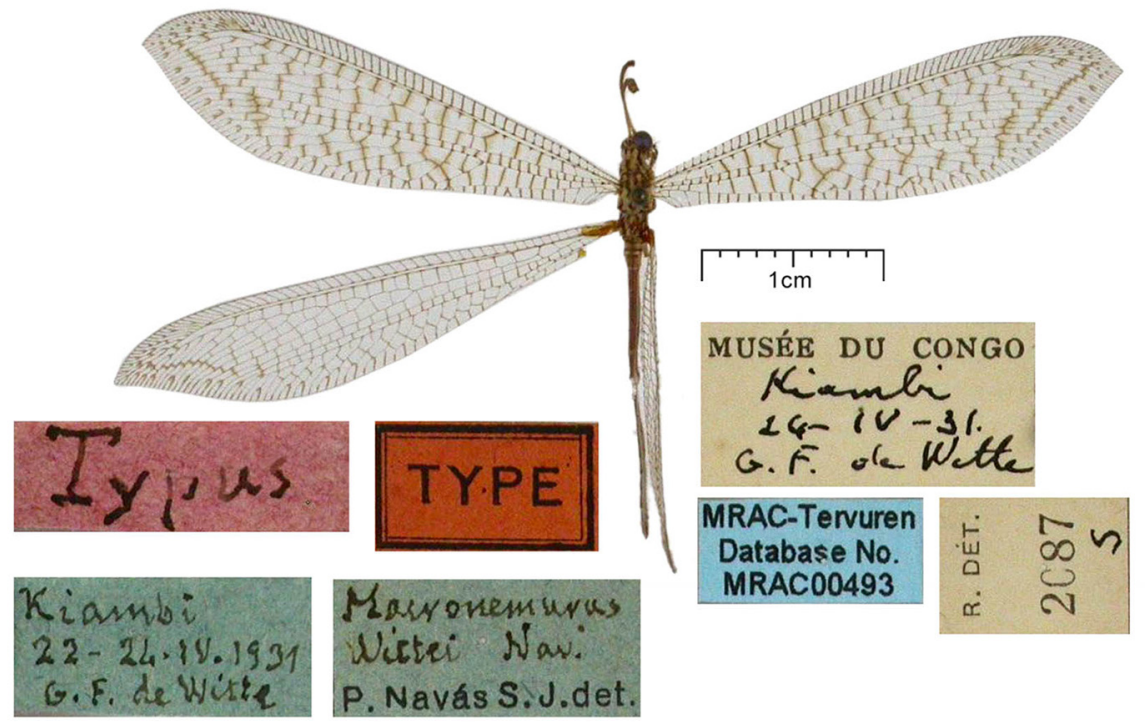

Fig. 43: Macronemurus wittei Navás, 1932 n. syn. of Macronemurus perlatus (Gerstaecker, 1885) 
Navás's handwriting] / P. Navás S.J. det. [printed] [blue label] // Kiambi / 22-24-IV. 1931 / G. F. de Witte [blue label with Navás's handwriting] // MRAC - Tervuren / database No / MRAC00493 [blue label] // R. dét / 2087 / S [white label] /".

In Navás (1932) "Kiambi 6.V.1931, 22-24.-IV.-1931. G. F. De Witte".

Type condition. Medium, tip of abdomen missing.

Comment. Macronemurus wittei Navás, 1932 is a new junior synonym of Macronemurus perlatus (Gerstaecker, 1885).

\section{Neuroleon erato Hölzel, 1972: 53 (Odescr).}

\section{Neuroleon erato Hölzel, 1972}

Syn. Neuroleon (Ganussa) lukhtanovi Krivokhatsky, 1996: 303 (Odescr), Mirmoayedi 2007 (Dist), Mirmoayedi et al. 1998, 2015, Khabiev \& Krivokhatsky 2014 (Dist), Krivokhatsky et al. 2015 (Dist), Dobosz et al. 2017 (Dist), Kerimova \& Krivokhatsky 2018 (Dist), n. syn., (Fig. 44).

Type of Neuroleon lukhtanovi. Paratype specimen checked, preserved in USMB.

Label information. "/ Paratypus [printed] / Neuroleon $q$ / luktanovi / Krivokhatsky [red label with Krivokhatsky's handwriting] // Berzingi Ashkhabad / Turkm.[enistan] 20-22. 06. [1]991 / Krivokhatsky [white label in Russian letters // 5858/ 14107 / coll. Upper Silesian Museum / (USMB) Bytom Poland [white label with black margins] /".

In KrivokHatsky (1996) "Holotype. đ̂, Uzbekistan, Kughitang Mountains, 10 km NE of Sherabad, 23.VI.1994 (V. Lukhtanov)".

Type condition. Paratype excellent.

Comment. Neuroleon lukhtanovi Krivokhatsky, 1996 is a new synonym of Neuroleon erato Hölzel, 1972.

Distribution of Neuroleon erato. It is a widespread species found in West Asia: Israel, Iran, Saudi-Arabia, Afghanistan, Pakistan (AsPöcK et al. 2001, MirmOAYEDI et al. 1998, 2015), in Caucasus region Dagestan (Russia) (KHABIEV \& KRIVOKHATSKY 2014), Georgia (Dobosz et al. 2017) and in the Central Asia: Tajikistan, Turkmenistan, Uzbekistan (KRIVOKHATSKY 1996, KRIVOKHATSKY et al. 2015), Kazakhstan, Kyrgyzstan (KHABIEV \& KRIVOKHATSKY 2014).

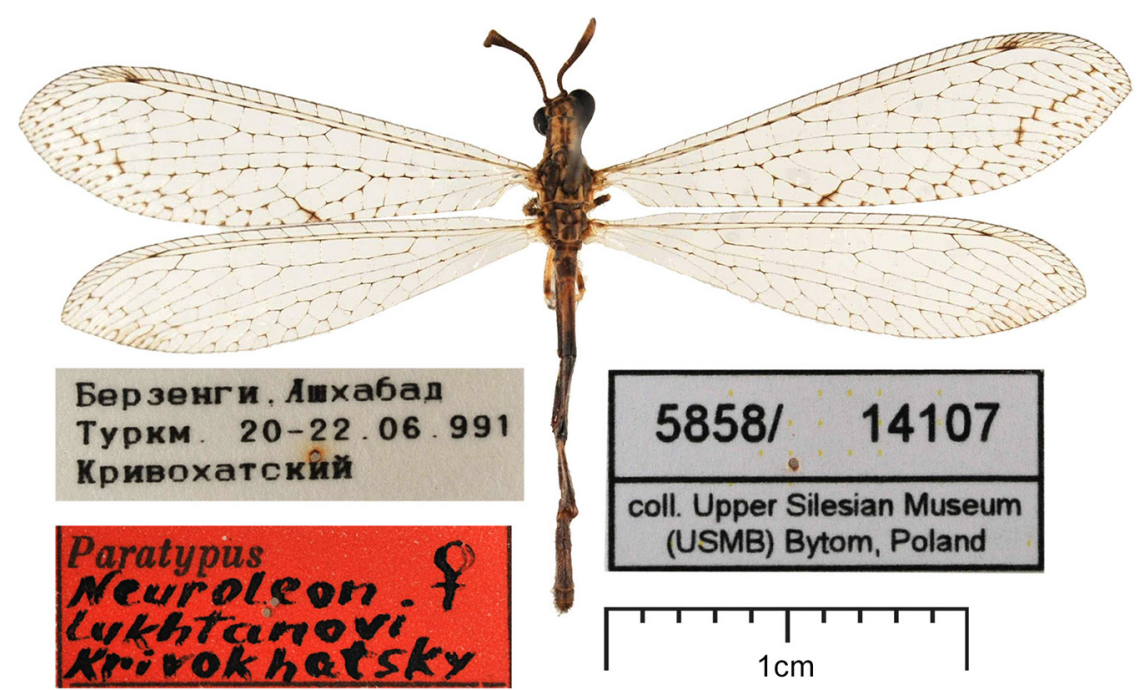

Fig. 44: Neuroleon lukhtanovi Krivokhatsky, 1996 n. syn. of Neuroleon erato Hölzel, 1972 
Neuroleon (Ganussa) tenellus (Klug in Ehrenberg, 1834)

Neuroleon (Ganussa) tenellus (Klug in Ehrenberg, 1834): 35 (Odescr).

Syn. Neuroleon nubilus Navás, 1913b: 452 (Odescr), Stange, 2004 (Mon), n. syn., (Fig. 45).

Type of Neuroleon nubilus. Female checked, preserved in BMNH.

Lectotype was designated by S. J. Brooks in 1984 in the collection but the designation has not been published yet.

Label information. "/ Type [round shaped white label with red margin] // Typus [red label with Navás's handwriting] // Oued Nssa / (de Ghardaïa to / Guerrara) / 3.-5. VI. 1912 / Haltert \& Hilg. [white label with black margins] // Neuroleon / nubilus / Nav. [with Navás's handwriting] / Navás S. J. det. [printed] [white label] // Brit. Mus. / $1927-$ 307 [white label] // 2 syntypes listed as / Ain Guettara \& Ouid Mya Sud / det. S. J. Brooks 1984 [in printed letters] [white label] // syn. of N. tenellus (Klug) / [ is this spec. selected to lecto- / type; / other syntype probably / lost [white label with handwriting] // QR code / BMNH(E) / 1253363 [white label] /".

In NavÁs (1913b) "Oued Nça (de Ghardaïa à Guerrara), 3-5 juin. 1 échantillon".

Type condition. Medium, antenna lost, right hindwing glued, abdomen missing but preserved in genital vial.

Comment. Neuroleon nubilus Navás, 1913 is a new junior synonym of Neuroleon (Ganussa) tenellus (Klug in Ehrenberg, 1834).

Distribution of Neuroleon tenellus. It is a widely distributed species known from South Europe (Aspöck et al. 2001) and North Africa (Morocco: ÁBRAHÁm 2017) via West Asia (ÁbrAhÁm \& VAN HARTEN 2014) to Middle Asia (KRIVOKHATSKY et al. 2015).

Pseudoformicaleo gracilis (Klug in Ehrenberg, 1834)

Pseudoformicaleo gracilis (Klug in Ehrenberg, 1834): 35 (Odescr).

Syn. Tahulus sordidatus Navás, 1936b: 113 (Odescr), n. syn., (Fig. 46).

Pseudoformicaleo sordidatus (Navás, 1936) - Stange 2004 (Comb).

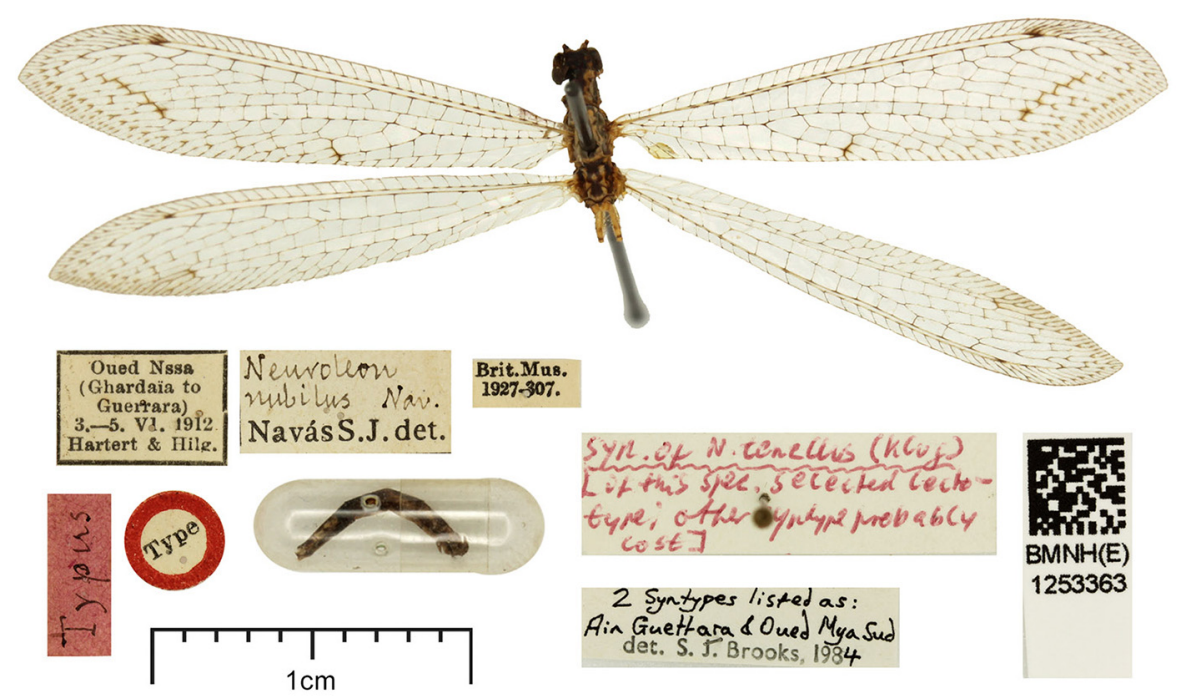

Fig. 45: Neuroleon nubilus Navás, 1913 n. syn. of Neuroleon (Ganussa) tenellus (Klug in Ehrenberg, 1834) 


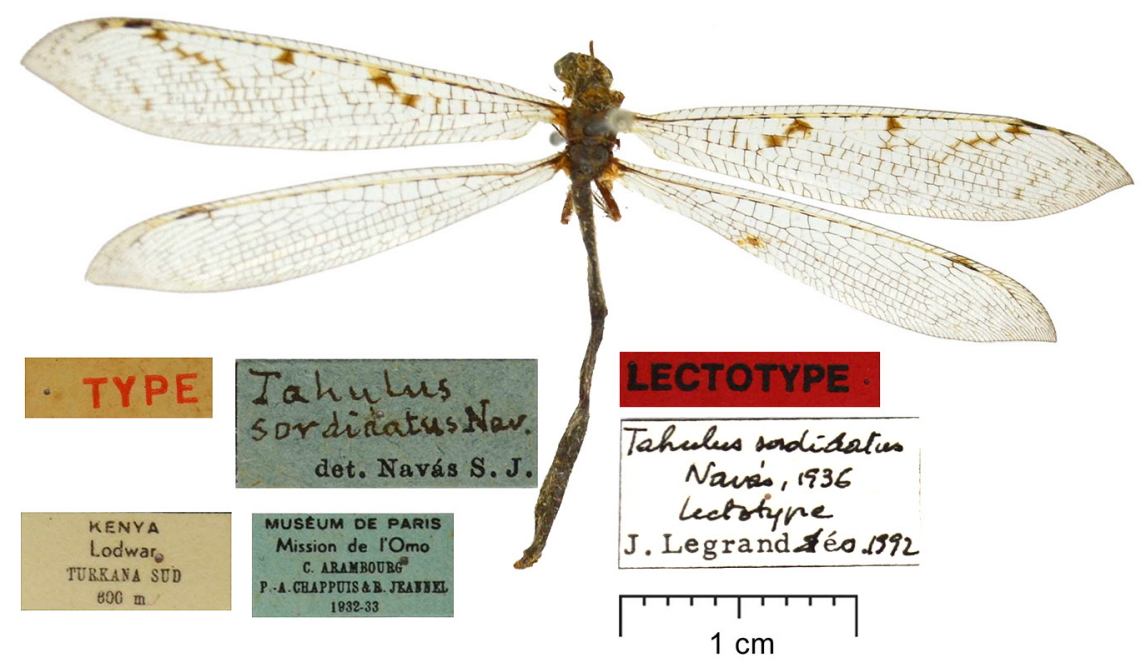

Fig. 46: Tahulus sordidatus Navás, 1936 n. syn. of Pseudoformicaleo gracilis (Klug in Ehrenberg, 1834)

Type of Tahulus sordidatus. Lectotype female checked, preserved in MNHP.

Lectotype was designated by Legrand "/ Lectotype [red label in capital printed letters] // Tahulus sordidatus / Navás, 1936 / Lectotype / J. Legrand dét. 1992 [white label with Legrand's handwriting]/".

Label information. "/ Type [white label in capital red letters] // Kenya / Lodwar / Turkana Sud / 600 m [white label] // Múseum de Paris / Mission de l'Omo / C. Arambourg / P. A: Chappuis \& R. Jeannel / 1932-33 [blue label] // Tahulus / sordinatus [sic] Nav. [with Navás's handwriting] / det. Navás S. J. [printed] [blue label] /".

In Navís (1936b) "Kénya: Lodwar, Turkana Sud, st. 37, 600 m”.

Synonymy is marked as "/ Pseudoformicaleo gracilis (Klug in Ehrenberg, 1834) / syn.: Ábrahám \& / Giacomino 2017 [white label in printed letters]/".

Type, condition. Good, antenna missing.

Comment. Tahulus sordidatus (Navás, 1936) is a new synonym of Pseudoformicaleo gracilis (Klug in Ehrenberg, 1834).

Distribution of Pseudoformicaleo gracilis. It is a widespread species in the Saharan zone: Morocco Tunisia Algeria, Egypt, Iran, Israel, Turkey, Syria, Oman, Saudi Arabia (StAnge 2004) and Kenya (Navís 1936b).

Tribe Glenurini Banks, 1927

Indoleon tacitus (Walker, 1853): 362 (Odescr).

Indoleon tacitus (Walker, 1853)

Syn. Indoleon tacitus sinicus C.-k. Yang in C.-k. Yang \& X.-1. Wang, 2002: 297 (as "tacirtus [sic] sinecus [sic]") (Odescr), Wang et al. 2018 (Mon), Yang et al. 2018 (Chlist), n. syn., (Fig. 47).

Type of Indoleon tacitus sinicus. Holotype checked, preserved in CAUB.

Label information. "/ Holotype [white label with red brand in capital white letters] // ????? [handwritten in Chinese]] / 1980. 05. 6. / ????? [handwritten in Chinese] / ????? [handwritten in Chinese] [white label with black margins] // Indoleon tacirtus / sinecus 
/ ????? [handwritten in Chinese] [white label with handwriting] // CAU-N / 101866 [white label with black upper and lower margins] /".

In YANG \& WANG (2002) "Nainan [sic] Prov. Mt. Limushan 1980. V. 6."

Type condition. Medium, antennae, legs and tip of abdomen missing.

Comment. Indoleon tacitus sinicus C.-k. Yang in C.-k. Yang \& X.-1. Wang, 2002 is a new junior synonym of Indoleon tacitus tacitus (Walker, 1853). According to Oswald (2019) the name of the species was misprinted in the original paper (YANG \& WANG 2002).

Distribution of Indoleon tacitus. China (Hainan) (YANG \& WANG 2002), Malaysia (WALKER 1853), Laos (unpublished data in coll. Rippl-Rónai Museum, Kaposvár).

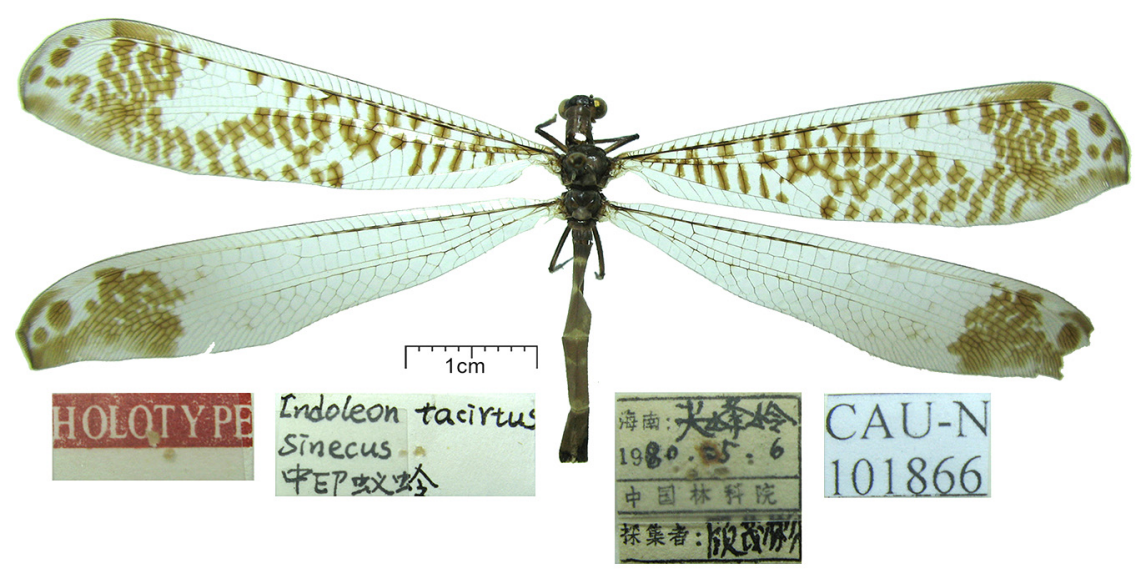

Fig. 47: Indoleon tacitus sinicus C.-k. Yang in C.-k. Yang \& X.-l. Wang, 2002 n. syn. of Indoleon tacitus tacitus (Walker, 1853)

Nedroledon lagopus (Gerstaecker, 1894) n. comb.

Myrmeleon lagopus Gerstaecker, 1894: 143 (Odescr), Hölzel 1972 (Chlist), Aspöck et al. 2001 (Chlist), Canbulat 2007 (Chlist), Stange 2004 (Mon), (Fig. 48).

Syn. Nedroledon striatus Hölzel, 1972: 65 (Odescr), Şengonca 1979 (Dist), Satar \& Özbay 2004 (Dist),

Canbulat 2007 (Chlist), Aspöck et al. 2001 (Mon), Stange 2004 (Mon), Mirmoayedi et al. 2015 (Chlist), n. syn.

Type of Nedroledon lagopus. Checked, preserved in EMAU.

LECTOTYPE (present designation). female "/ Lectotype / Myrmeleon lagopus / Gerstaecker, 1894 / design.: Ábrahám \& / Giacomino 2019 [red label] /".

Label information. "/ lagopus / Gerst* / Mardin Stdgr. [white label with narrow black margins and with Gerstaecker's handwriting] // M. lagopus / Gerst* / Mardin / Stgr. / [with glued tip of abdomen and white label handwritten in pencil] // Zool. Mus. / Greifswald / II 27438 [white label] /".

In GerSTAECKER (1894) "Mardin, Mesopotamiae [today SE Turkey]".

Type condition. Medium, antenna and some legs broken and lost, tip of abdomen broken but glued to label.

Comment. Myrmeleon lagopus Gerstaecker, 1894 is moved to Nedroledon Navás, 1914. HöLzEL (1972) marked it as nomina dubia in the checklist of the Middle East Asia. 


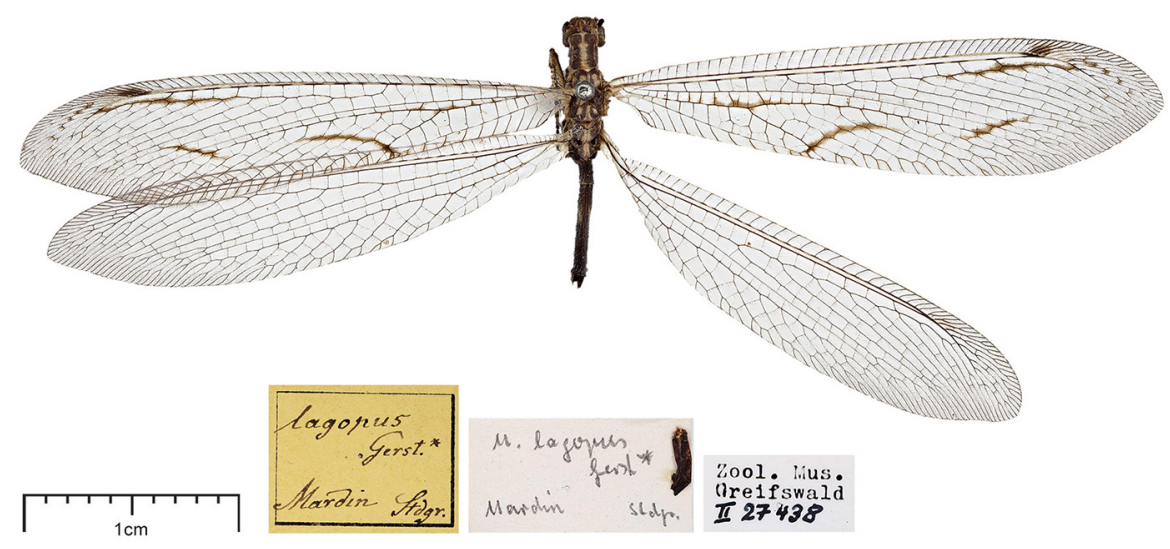

Fig. 48: Lectotype of Myrmeleon lagopus Gerstaecker, 1894 n. comb. of Nedroledon lagopus (Gerstaecker, 1894)

AsPöcK et al. (2001) supposed that the type material had been lost and taxonomical status of the species left incertae sedis. CANBulat (2007) also listed in the Turkish Neuroptera checklist without any comments. The lectotype specimen is not typical since A2 simple instead of forking in both forewings otherwise it agrees with all characters of genus Nedroledon Navás, 1914. Nedroledon striatus Hölzel, 1972 is a new junior synonym of Nedroledon lagopus (Gerstaecker, 1894). The genus of Nedroledon Navás, 1914 contains characteristically different species and should be divided into at least two genera.

Distribution of Nedroledon lagopus. This species was collected in Turkey (GERSTAECKER 1894, ŞEngonca 1979, Satar \& Özbay 2004, Canbulat 2007) and Iran (Hölzel 1972, AsPÖCK et al. 2001).

Paraglenurus pumilus (C.-k. Yang, 1997)

Glenuroides pumilus C.-k. Yang, 1997: 616 (Odescr), Yang, C.-k. 1999 (Dist), (Fig. 49).

Paraglenurus pumilus (Yang, 1997) - Stange 2004 (Comb), Wang et al. 2018 (Mon), Yang et al. 2018 (Chlist).

Syn. Paraglenurus lotzi Miller \& Stange, 1999: 58 (Odescr), n. syn.

Type of Paraglenurus pumilus. Holotype male checked, preserved in CAUB.

Label information. "/ Holotype / $\widehat{\partial}$ [white label with red brand in capital white letters] // ????? [text in Chinese letters] / 1980 ? [text in Chinese letters] 9 [? text in Chinese letters] 26 / [? text in Chinese letters] / ????? [text in Chinese letters] [white label] // ????? [text in Chinese letters] / Glenuroides / pumilus / Yang, 1997 / Det. Jikun Yang [white label with black margins] // CAU-N / 101837 [white label with black upper and lower margins] //.

In Yang (1997) "Holotype $\widehat{\partial}$, Dongshan Co., Fujian Prov., 1980-IX-26."

Type condition. Good, antenae and two legs missing.

Comment. Paraglenurus lotzi Miller \& Stange, 1999 is a new junior synonym of Paraglenurus pumilus Yang, 1997. Synonymy based on accurate description and figures (Miller \& Stange 1999)

Distribution of Paraglenurus pumilus. Only the published type material is known from China (Fujian) (YANG 1997) and Taiwan (MiLler et al. 1999). 


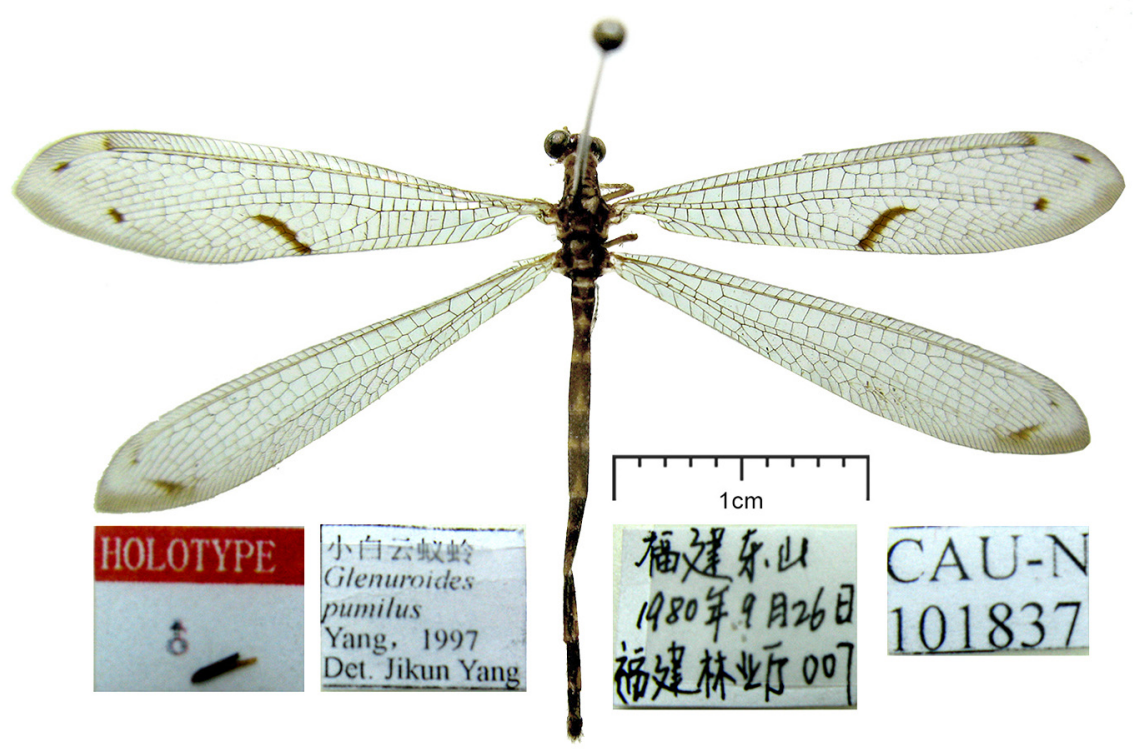

Fig. 49: Holotype of Paraglenurus pumilus (C.-k. Yang, 1997)

\section{Acknowledgement}

We are grateful to the following persons for providing access to the collections in their care and providing excellent photographs: J. Legrand (MNHP), Prof. Dr. Wang Xinli (CAUB), Dr. B. Price (BMNH), Dr. P. Michalik (EMAU), Dr. M. Tavano and R. Poggi (MCSN), Dr. R. Dobosz (USMB), Dr. M. Ohl and B. Schurian (ZMHB), A. Spooner (OXUM), Dr. S. Randolf (NHMW). 


\section{References}

Aspöck, H.; Hölzel, H. 1996: The Neuropteroidea of North Africa, Mediterranean Asia and of Europe: a comparative review (Insecta). - Pp. 31-86 in Canard, M.; Aspöck, H.; Mansell, M. W. (eds.). Pure and Applied Research in Neuropterology. Proceedings of the Fifth International Symposium on Neuropterology (2-6 May 1994, Cairo, Egypt). Privately printed, Toulouse, France. 341 pp.

Aspöck, H.; Aspöck, U.; Hölzel, H.[; Rausch, H.] 1980: Die Neuropteren Europas. Goecke and Evers, Krefeld, West Germany. Vol.1.: 495 pp. Vol. 2.: 355 pp.

Aspöck, H., Hölzel, H. and Aspöck, U. 2001: Kommentierter Katalog der Neuropterida (Insecta: Raphidioptera, Megaloptera, Neuroptera) der Westpaläarktis. - Denisia 2: 1-606.

Akhtar, S.; Ashfaq, M.; Zia, A.; Ali, S.; Ali, G. M.; Farhatulla; Zafar, Y. 2018: First report and redescription of five species of genus Myrmeleon (Neuroptera: Myrmeleontidae) from Pakistan. Journal of Biodiversity and Environmental Sciences 13:180-190.

ÁbraHÁm L. 2017: New data to the Moroccan Myrmeleontiformia (Nemopteridae, Myrmeleontidae, Ascalaphidae) fauna. - Natura Somogyiensis 30: 75-138.

ÁвraнÁm, L. \& Dobosz, R. 2011: Contribution to the ant-lion and owl-fly fauna of Madagascar with description of new taxa (Neuroptera: Myrmeleontidae, Ascalaphidae). - Natura Somogyiensis 19: 109-137.

ÁbrahÁm L. \& A. van HARTEn 2014: Order Neuroptera, family Myrmeleontidae. - Arthropod fauna of the United Arab Emirate 5: 299-333.

Banks, N. 1911: Notes on African Myrmeleonidae. - Annals of the Entomological Society of America 4:1[31].

Banks, N. 1913: Notes on African Myrmeleonidae. - Journal of the New York Entomological Society 21: 149157.

BAnKs, N. 1920: Neuroptera, Panorpata, and Trichoptera collected by the American Museum Congo Expedition, with lists of the species known from the Belgian Congo. - Bulletin of the American Museum of Natural History 43:21-33.

Bodenheimer, F. S. 1937: Prodromus faunae Palestinae: essai sur les éléments zoogéographiques et historiques du sud-ouest du sous-règne paléarctique. - Mémoires présentés à l'Institut d'Egypte 33:ii + $1-286$.

CAnbulat, S. 2007: A checklist of Turkish Neuroptera with annotating on provincial distributions. - Zootaxa 1552: $35-52$.

DevetaK, D.; Podlesnik, J.; Klokočovnik, V.; JanŽekovič, F. 2013: Antlions (Insecta: Neuroptera: Myrmeleontidae) of Albania. - Turkish Journal of Zoology 37: 362-366.

Dobosz, R., Krivokhatsky, V., Wąsala, R., Plewa, R. \& Aladashvili, N. 2017: New data on the occurrence of lacewings (Neuroptera) in Georgia. - Acta Entomologica Silesiana Vol. 25 (online 002): 1-10.

El-Hamouly H. \& Hassan H. Fadl 2011: Checklist of order Neuroptera in Egypt, with a key to families. African Journal of Biolology Scienes 7(1): 85-104.

ESBEN-PETERSEN, P. 1920: Revision of some of the type-specimens of Myrmeleonidae, described by Navas and placed in the Vienna Museum. - Annales de la Société Entomologique de Belgique 60: 190-196.

Esben-Petersen, P. 1928a: Neuroptera Planipennia. - Pp. 203-221 in Michaelsen, J. W. (ed.). Beiträge zur Kenntnis der Land- und Süsswasserfauna Deutsch-Südwestafrikas, Ergebnisse der Hamburger DeutschSüdwestafrikanischen Studienreise 1911. Vol. 2. Friederichsen and Co., Hamburg

Esben-Petersen, P. 1928b: Neuroptera and Embiidina from Abyssinia and Somaliland. - Annals and Magazine of Natural History (10)1: 442-450.

Esben-Petersen, P. 1931: Wissenschaftliche ergebnisse der mit unterstützung der akademie der wissenschaften in Wien aus der erbschaft treitl von F. Werner unternommenen zoologischen expedition nach dem Anglo-Ägyptischen Sudan (Kordofan) 1914. XXVII. Neuropteren. - Denkschriften, Akademie der Wissenschaften Wien, Mathematische-Naturwissenschaftliche Klasse 102: 201-206.

Fraser, F. C. 1950: Contribution a l'étude de l'Aïr (Mission L. Chopard et A. Villiers). Odonata and Neuroptera. - Mémoires de l'Institut Français d'Afrique Noire 10:108-126.

Fraser, F. C. 1951: Notes on the Neuroptera of Madagascar. Part 2. The Myrmeleontidae and Ascalaphidae. - Memoires de l'Institut Scientifique de Madagascar (A)5:347-357.

Fraser, F. C. 1952: Contribution à l'étude du peuplement de la Mauritanie. Odonata, Neuroptera, Nemoptera and Ephemeroptera. - Bulletin de l'Institut Française d'Afrique Noire 14:479-484.

Gerstaecker, [C. E.] A. 1884: [1885.] Vier Decaden von Neuropteren aus der Familie Megaloptera Burm. Mitt[h]eilungen aus dem Naturwissenschaftlichen Verein für Neu-Vorpommern und Rugen 16: 1-49. 
Gerstaecker, [C. E.] A. 1894: Ueber neue und weniger gekannte Neuropteren aus der familie Megaloptera Burm. - Mitt[h]eilungen aus dem Naturwissenschaftlichen Verein für Neu-Vorpommern und Rugen 25: 93-173.

Giacomino M. \& ÁbraHÁm L., 2018: Little-known and synonymous antlions (Neuroptera, Myrmeleontidae). - Bulletin de la Société entomologique de France, 123(1): 85101.

Ghosh, S. K. 1981: On new and little-known species of Planipennia (Order Neuroptera) from India. - Bulletin of the Zoological Survey of India 4: 131-139.

GHosh, S. K. 1983: Notes on the biogeography of Neuroptera: Planipennia from certain areas of the north-west Himalayan and northern peninsular sector of India. Records of the Zoological Survey of India 80: 291300.

GHosh, S. K. 1984: Contribution to the taxonomical studies of Neuroptera (Suborder Planipennia) from eastern India. 1. Family Myrmeleontidae. - Records of the Zoological Survey of India, Miscellaneous Publications, Occasional Paper 52:vi + 1-63 + [23].

GHosh, S. K. 1991: Interesting species of Neuroptera from Himachal Pradesh. Records of the Zoological Survey of India 89: 89-94.

Ghosh, S. K. 1997: Neuroptera. Pp. 65-66 in Alfred, J. R. B. (ed.). Fauna of Nanda Devi Biosphere Reserve. A world heritage site. Zoological Survey of India, Calcutta. Fauna of Conservation Areas. Vol. 9. iii +166 pp.

Ghosh, S. K. 2000: Neuroptera fauna of north-east India. - Records of the Zoological Survey of India, Miscellaneous Publications, Occasional Paper 184:xiii+1-179.

Ghosh, S. K. \& SEN, S. 1977: Check-list of Indian Planipennia (Order Neuroptera). - Records of the Zoological Survey of India 73: 277-326.

Gravely, F. H.; MauliK, S. 1911: Notes on the development of some Indian Ascalaphidae and Myrmeleonidae. - Records of the Indian Museum, Calcutta 6: 101-110.

HaGen, H. A. 1866: Hemerobidarum Synopsis synonymica. - Stettiner Entomologische Zeitung 27:369-462.

HANDSCHIN, E. 1963: Beitrag zur Kenntnis der Neuropterenfauna von Madagascar. - Mitteilungen der Schweizerischen Entomologischen Gesellschaft (Zurich) 35: 211-226.

HöLzEL, H. 1970: Ergebnisse der zoologischen Forschungen von Dr. Z. Kaszab in der Mongolei. 222. Beitrag zur Kenntnis der Myrmeleoniden der Mongolei (Neuroptera: Planipennia). - Acta Zoologica Academiae Scientiarum Hungaricae 16:115-136.

Hölzel, H. 1972: Die Neuropteren Vorderasiens IV. Myrmeleonidae. - Beiträge zur Naturkundlichen Forschung in Südwestdeutschland, Beiheft 1:3-103.

HöLzel, H. 1982: Insects of Saudi Arabia. Neuroptera: Fam. Myrmeleonidae [Part 1]. - Fauna of Saudi Arabia 4: 244-270.

Hölzel, H. 1987: Revision der Distoleonini. I. Die Genera Macronemurus Costa, Geyria Esben-Petersen und Mesonemurus Navás (Planipennia, Myrmeleonidae). - Entomofauna 8: 369-410.

Kerimova, I. G.; KrivoKнатsKy, V. A. 2018: Современный состав фауны муравьиных львов (Neuroptera: Myrmeleontidae) Азербайджана [=Current composition of the fauna of antlions (Neuroptera: Myrmeleontidae) of Azerbaijan]. - Кавказский Ентомологический Бюллетень [=Kavkazskij Entomologičeskij Bjulleten; =Caucasian Entomological Bulletin] 14: 55-66.

Khabiev, G. N., Krivokhatsky, V.A. 2014. Rare species of antlions (Neuroptera: Myrmeleontidae) new for the fauna of Caucasian and Middle Asian countries. - Zoosystematica Rossica 23: 122-126.

KLAPÁLEK, F. 1912: Ergebnisse der mit Subvention aus der Erbschaft Treitl unternommenen zoologischen Forschungsreise Dr. Franz Werner's nach dem ägyptischen Sudan und Nord-Uganda. XVI. Neuropteren. - Sitzungsberichte der Akademie der Wissenschaften in Wien, Mathematische-Naturwissenschaftliche Klasse (Abtheilung I) 121: 143-148.

KLUG J. C. F. 1834: Symbolae physicae, seu icones et descriptiones Insectorum, quae ex itinere per Africam borealem et Asiam occidentalem F.G. Hemprich et C.G. Ehrenberg studio novae aut illustratae redierunt. Bd. 4. Berlin, 1829 - 45: pl. 35, 36.

Kolbe, H. J. 1897: Neuropteren. Die Netzflügler. in Möbius, K. A. (ed.). - Die Thierwelt [Deutsch-]OstAfrikas und der Nachbargebiete. Band IV (Wirbellose Thiere). Dietrich Reimer, Berlin. [i] + 42 pp.

Krivokhatsky, V. A. 1996. Antlions of the subgenus Ganussa (genus Neuroleon) from Middle Asia (Neuroptera: Myrmeleontidae). - Zoosystematica Rossica 4: 301-306.

KRIVOKHATSKY, V. A. 1997: Новый и малоизвестные виды муравьных львов (Neuroptera, Myrmeleontidae) из Индокитая [=A new and little known species of ant-lions (Neuroptera, Myrmeleontidae) from IndoChina]. - Энтомологическое Обозрение [=Entomologicheskoe Obozrenie] 76: 631-640. 
Krivokhatsky, V. A. 2005a: Black-striped morphs of antlions (Neuroptera, Myrmeleontidae). Entomologicheskoe Obozrenie 84: 159-163.

Krivokhatsky, V. A. 2005b: L. Stange. A systematic catalog, bibliography and classification of the world antlions (Insecta: Neuroptera: Myrmeleontidae). Memoirs of the American Entomological Institute. Volume 74. Gainesville, FL. 2004. 565 pp. - [=Zoologicheskii Zhurnal; =Zoological Journal] 84: 471474.

Krivokhatsky, V. A.; Emeljanov, A. F.; Lobanov, A. L. 1996: The distribution of antlions in Mongolia (Insecta: Neuroptera: Myrmeleontidae). - Pp. 147-159 in CANARd, M.; Aspöck, H.; Mansell, M. W. (eds.). Pure and Applied Research in Neuropterology. Proceedings of the Fifth International Symposium on Neuropterology (2-6 May 1994, Cairo, Egypt). Privately printed, Toulouse, France. 341 pp.

KrivokнAтsky, V. A. 2011: Муравьиные львы (Neuroptera: Myrmeleontidae) России [=Antlions (Neuroptera: Myrmeleontidae) of Russia]. Товарищество Научных Изданий KMK [=KMK Scientific Press], СанктПетербург [=St. Petersburg]. 334 pp.

Krivokhatsky, V.A.; Shapoval, N.A.; Shapoval, A. P. 2014: Муравьиные львы (Neuroptera, Myrmeleontidae) В орнитологических ловушках на Куршской косе: трехвидовое сообщество с новым для науки видом [=Antlions (Neuroptera, Myrmeleontidae) from ornithological traps on the Curonian spit: a threespecies community containing a new species]. - Зоологический Журнал [=Zoologicheskii Zhurnal; =Zoological Journal] 93: 171-178.

Krivokhatsky, V. A.; Dobosz, R.; Khabiev, G. N. 2015: Antlions and owlflies (Neuroptera: Myrmeleontidae, Ascalaphidae) of Kyrgyzstan. - Entomologicheskoe Obozrenie 94: 803-818.

LinNAEUS, C. 1758: Systema natura per regna tria naturae secundum classes, ordines, genera, species, cum characteribus, differentiis, synonymis, locis. Editio decima, reformata [10th Edition]. Tomus I [=Vol. 1]. Salvii, Holmiae. 824 pp.

LinNAEus, C. 1767: Systema natura per regna tria naturae secundum classes, ordines, genera, species, cum characteribus, differentiis, synonymis, locis. Editio duodecima reformata [=12th Edition, revised]. Tom. I. Pars II [=Vol. 1, pt. 2; pp. 533-1327]. Laurentii Salvii, Holmiae.

Mansell, M. W. 1985: The ant-lions of southern Africa (Neuroptera: Myrmeleontidae). Introduction and genus Bankisus Navás. - Journal of the Entomological Society of Southern Africa 48: 189-212.

Mansell, M. W. 2000: Neuroptera (Insecta). - in KirK-SpriggS, A. H.; Marais, M. (eds.). Dâures-biodiversity of the Brandenberg Massif, Namibia. - Cimbebasia Memoir 9: 163-176.

MCLACHLAN, R. 1868: New genera and species, \&c., of neuropterous insects; and a revision of Mr. F. Walker's British Museum Catalogue of Neuroptera, part ii. (1853), as far as the end of the genus Myrmeleon. Journal of the Linnean Society of London, Zoology 9: 230-281.

Michel, B.; Letourmy, P. 2007: Characterisation of a west African Myrmeleontinae assemblage (Neuroptera Myrmeleontidae): first evidence of a relationship between adult occurrences and climatic conditions. Tropical Zoology 20:197-209.

Miller, R. B.; Stange, L. A.; Wang, H.-Y. 1999: New species of antlions from Taiwan (Neuroptera: Myrmeleontidae). - Journal of the National Taiwan Museum [=Guo li Taiwan bo wu guan] 52: 47-78.

MirmoAYEDI, A. 2007: Records of three species of ant-lions (Neuroptera: Myrmeleontidae), new for the fauna of Iran. - Zoology in the Middle East 41: 115-117.

Mirmoayedi, A., Krivokhatsky, V. \& Dobosz, D. 2015: Annotated check-list of the antlions of Iran (Neuroptera:Myrmeleontidae). - Acta Entomologica Silesiana Vol. 23 (online 025): 1-16.

Mirmoayedi, A.; Zakharenko, A. V.; Krivokhatsky, V. A.; Yassayie, A. 1998: К фауне сетчатокрылых (Insecta: Neuroptera) национального парака Гулистан и провинции Керманшах (Иран) [=K faune setchatokrylykh (Insecta, Neuroptera) national'nogo parka Gulistan Provintsii Kermanshakh (Iran); =On the lacewing fauna (Insecta, Neuroptera) of the Golestan National Park and Kermanshah Province (Iran)]. Известия Харьковского Энтомологического Общества [=Izvestiya Kharkovskogo Entomologicheskogo Obshchestva; =Kharkov Entomological Society Gazette] 6(2): 53-56.

NAvÁs, L. 1912a: Notas sobre Mirmeleónidos (Ins. Neur.). - Brotéria (Zoológica) 10: 29-75, 85-97.

NAvís, L. 1912b: Insectos neurópteros nuevos o poco conocidos. - Memorias de la Real Academia de Ciencias y Artes de Barcelona (3)10: 135-202.

NAvís, L. 1912c: Myrméléonides (Ins. Névr.) nouveaux ou peu connus. - Annales de la Société Scientifique de Bruxelles 36(pt. 2): 203-248.

NAvÁs, L. 1912d: Notes sur quelques Névroptères d'Afrique. III. Myrméléonides nouveaux. Revue de Zoologie Africaines, Bruxelles 2: 35-43.

NAvás, L. 1913a: Notes sur quelques Névroptères. VI. Névroptères d'Afrique nouveaux. - Insecta, Rennes 3: 265-272. 
NAvás, L. 1913b: Expedition to the central western Sahara. X. Quelques Névroptères du Sahara Français. Novitates Zoologicae 20: 444-458.

Navás, L. 1913c: Mis excursiones por el extranjero en el verano de 1912 (25 julio - 16 septiembre). - Memorias de la Real Academia de Ciencias y Artes de Barcelona (3)10: 479-514.

Navás, L. 1914a: Voyage de Ch. Alluaud et R. Jeannel en Afrique Orientale (1911-1912). Résultats scientifiques. Insectes Névroptères. I. Planipennia et Mecoptera. Paris. 52 pp.

Navás, L. 1914b: [Neuroptera nova africana.] III series. - Memorie dell'Accademia Pontifica dei Nuovi Lincei, Rome (1)32: 99-108.

NAvÁs, L. 1914c: Neuropteros nuevos de Africa. - Memorias de la Real Academia de Ciencias y Artes de Barcelona (3)10: 627-653.

NAvís, L. 1914d: Myrméléonides (Ins. Névr.) nouveaux ou critiques [I]. - Annales de la Société Scientifique de Bruxelles 38(pt. 2): 229-254.

Navás, L. 1915a: Neurópteros nuevos o poco conocidos (Cuarta [IV] serie). - Memorias de la Real Academia de Ciencias y Artes de Barcelona (3)11: 373-398.

NAvís, L. 1915b: Neuroptera nova africana. IV Series. - Memorie dell'Accademia Pontifica dei Nuovi Lincei, Rome (2)1: 9-19.

NAVÁs, L. 1919 [1921]: Comunicaciones entomológicas. 3. Insectos exóticos. - Revista de la [Real] Academia de Ciencias Exactas Fisico-Quimicas y Naturales de Zaragoza (1)4: 287-306.

NAvÁs, L. 1922: [Sur des] Névroptères nouveaux ou critiques. Cinquième [V] série. - Annales de la Société Scientifique de Bruxelles 41(pt. 1): 250-256.

NAVÁs, L. 1923: Névroptères de Barbarie. Quatrième [IV] série. - Bulletin de la Société d'Histoire Naturelle de l'Afrique du Nord 14: 339-340.

Navás, L. 1924: Algunos insectos del Museo de París. 2.a serie [IIa]. - Brotéria (Zoológica) 21: 99-114.

NAvás, L. 1926a: Insecta orientalia. IV series. - Memorie dell'Accademia Pontifica dei Nuovi Lincei, Rome (2)9: 111-120.

Navás, L. 1926b: Névroptères d'Egypte et de Palestine. 2me partie. - Bulletin de la Société [Royale] Entomologique d'Egypte 10: 26-62.

NAvás, L. 1928: Insectos del Museo de Estocolmo. - Revista de la Real Academia de Ciencias Exactas Fisicas y Naturales de Madrid 24: 28-39.

NAvás, L. 1929: [Insecta orientalia.] VII Series. - Memorie dell'Accademia Pontifica dei Nuovi Lincei, Rome (2) $12: 43-56$.

Navás, L. 1930a: Insectes du Congo Belge (Série IV). - Revue de Zoologie et de Botanique Africaines 19: 305-336.

NAvás, L. 1930b [1931]: Comunicaciones entomológicas. 13. Insectos de la India. 3.a serie. - Revista de la [Real] Academia de Ciencias Exactas Fisico-Quimicas y Naturales de Zaragoza (1)14: 74-92.

Navás, L. 1931: Insectes du Congo Belge (Série V). - Revue de Zoologie et de Botanique Africaines 20: $257-$ 279.

Navás, L. 1932: Insectes du Congo Belge. Série VII. - Revue de Zoologie et de Botanique Africaines 22: 269290.

NAvás, L. 1933a: Neurópteros exóticos [1.a serie]. - Memorias de la Real Academia de Ciencias y Artes de Barcelona (3)23:203-216.

NAvÁs, L. 1933b: Insectes neuròpters i afins de Barbaria. Sèrie 9.a. - Butlletí de la Institució Catalana d'Història Natural (2)13[=33]: 227-229.

Navás, L. 1933c: Insectes du Congo Belge. Série VIII. - Revue de Zoologie et de Botanique Africaines 23: 308-318.

NAVÁs, L. 1934a: Comunicaciones entomológicas. 17. Insectos de Madagascar. Primera [I] serie. - Revista de la [Real] Academia de Ciencias Exactas Fisico-Quimicas y Naturales de Zaragoza (1)17: 49-76.

NAvás, L. 1934b: Comunicaciones entomológicas. 18. Insectos de Madagascar. Segunda [II] serie. - Revista de la [Real] Academia de Ciencias Exactas Fisico-Quimicas y Naturales de Zaragoza (1)18: 42-74.

NAvás, L. 1936a: Insectes du Congo Belge. Série IX. - Revue de Zoologie et de Botanique Africaines 28: 333 368.

NAVÁs, L. 1936b: Mission Scientifique de l'Omo. Tome III. Fascicule 19. Neuroptera, Embioptera, Plecoptera, Ephemeroptera et Trichoptera. - Memoires du Museum Nationale d'Histoire Naturelle, Paris (N.S.)4:101-128.

NAvás, L. 1937: Myrméléonidés nouveaux. - Comptes Rendus XIIe Congres International de Zoologie (Lisbon 1935). 2: 1472-1479. 
Needham, J. G. 1909: Notes on the Neuroptera in the collection of the Indian Museum. - Records of the Indian Museum, Calcutta 3: 185-210.

New, T. R. 1985a: A revision of the Australian Myrmeleontidae (Insecta: Neuroptera). I. Introduction, Myrmeleontini, Protoplectrini. Australian Journal of Zoology, Supplementary Series 104: 1-90.

New, T. R. 1985b: A revision of the Australian Myrmeleontidae (Insecta: Neuroptera). II. Dendroleontini. Australian Journal of Zoology, Supplementary Series 105: 1-170.

New, T. R. 1985c: A revision of the Australian Myrmeleontidae (Insecta: Neuroptera). III. Distoleontini and Acanthaclisinae. Australian Journal of Zoology, Supplementary Series 106: 1-159.

Penny, N. D. 2004: Neuroptera, lacewings. - Pp. 663-669 in Goodman, S. M. \& Benstead, J. P. (eds.). Natural History of Madagascar. University of Chicago Press, Chicago. 1728 pp.

Poggi, R. 1993: Catalogo dei tipi di Neurotteroidei del Museo Civico di Storia Naturale "G. Doria" di Genova (Insecta) [=Catalogue of the Neuropteroidea types in the Museo Civico di Storia Naturale "G. Doria", Genoa (Insecta).]. - Annali del Museo Civico di Storia Naturale Giacomo Doria 89: 415-444.

Prost, A. 1998: Les Acanthaclisinae d'Afrique occidentale et centrale [Neuroptera, Myrmeleontidae]. - Revue Française d'Entomologie (N.S.)20: 157-173.

RAmbur, [J.] P. 1842: Histoire naturelle des insectes, névroptères. - Librairie encyclopédique de Roret. Fain et Thunot, Paris. [xviii] $+534 \mathrm{pp}$.

RöHricht, W. 1998: Distribution of Myrmeleon (Morter) bore (Tjeder, 1941). in Panelius, S. P. (ed.). Neuropterology 1997. Proceedings of the Sixth International Symposium on Neuropterology (13-16 July 1997, Helsinki, Finland). - Acta Zoologica Fennica 209: 221-225.

SATAR, A. \& ÖZBAY, C. 2004: Remarks on Neuroptera of southeastern Turkey. - Entomologica Fennica 15: 219-224.

ŞENGONCA, Ç. 1979: Beitrag zur Neuropterenfauna der Türkei. - Nachrichtenblatt der Bayerischen Entomologen 28: 10-15.

StAnge, L. A. 1976: Clasificacion y catalogo mundial de la tribu Dendroleontini con la redescripcion del genero Voltor Navás (Neuroptera: Myrmeleontidae). - Acta Zoológica Lilloana 31: 261-320.

STANGE L. A., 2004: A systematic catalog, bibliography and classification of the world antlions (Insecta: Neuroptera: Myrmeleontidae). - Memoirs of the American Entomological Institute, 74: iv + 565 .

Stein, J. P. E. F. 1863: Beitrag zur Neuropteren-fauna Griechenlands (mit Berücksichtigung dalmatinischer Arten). - Berliner Entomologische Zeitschrift 7: 411-422.

Tauber, C. A.; Simmons, Z.; Tauber, A. J. 2019: Type specimens of Neuropterida in the Hope Entomological Collection, Oxford University Museum of Natural History. - ZooKeys 823: 1-126.

VAN der WeELe, H. W. 1909: Les Planipennia recueillis par le Prof. Voeltzkow a Madagascar et dans les iles environnantes. - Bulletin Scientifique [or Biologique] de la France et de la Belgique 42: 61-68.

van der Weele, H. W. 1910: Neuroptera. 2. Planipennia et Panorpata. Pp. 11-23. in SJöstedt, Y. (ed.). Wissenschaftliche ergebnisse der Schwedischen Zoologischen expedition nach dem Kilimandjaro, dem Meru und den Umgebenden massaisteppen Deutsch-Ostafrikas 1905-1906. Vol. 2, No. 13.

WALKER, F. 1853: List of the specimens of neuropterous insects in the collection of the British Museum. Part II.--(Sialides--Nemopterides). - British Museum, London. [iii] + 193-476.

WALKER, F. 1860: Characters of undescribed Neuroptera in the collection of W. W. Saunders. Transactions of the [Royal] Entomological Society of London 10[=(N.S.)5]: 176-199.

WAN, X.; YANG, X.-K.; WANG, X.-L. 2004: Study on the genus Dendroleon from China (Neuroptera, Myrmeleontidae). - Dong Wu Fen Lei Xue Bao; [=Acta Zootaxonomica Sinica] 29: 497-508.

WANG, X.-L.; Ao, W.-G.; WANG, Z.-L.; WAN, X. 2012: Review of the genus Gatzara Navás, 1915 from China (Neuroptera: Myrmeleontidae). - Zootaxa 3408:34-46.

WANG, X.-L.; Zhan, Q.-B.; WANG, A.-Q. 2018: Fauna Sinica. Insecta Vol. 68. Neuroptera, Myrmeleontoidea. - Science Press, Beijing. [viii] $+\mathrm{x}+285 \mathrm{pp}$.

Whittington, A. E. 2002: Resources in Scottish Neuropterology. in Sziráki, G. (ed.). Neuropterology 2000. Proceedings of the Seventh International Symposium on Neuropterology (6-9 August 2000, Budapest, Hungary). - Acta Zoologica Academiae Scientiarum Hungaricae 48(Suppl. 2): 371-387.

YANG, C.-K. 1986: Thirty new species and four new genera of Neuroptera from Yunnan, and the family Nemopteridae new to China. - Acta Agriculturae Universitatis Pekinensis [=Peiching Nung Yeh Ta Hsueh Pao] 12:153-166, 423-434.

YANG, C.-K. 1987: Neuroptera. Pp. 191-220 in Zhang, S. (ed.). Xizang nong ye bing chong ji za cao [=Agricultural insects, spiders, plant diseases and weeds of Xizang]. Vol. 1 [of 2]. [1st edition.] - Xizang ren min chu ban she [=Xizang Renmin Press House], Xizang, China. 463 pp. 
YAng, C.-K. 1997: Neuroptera: Myrmeleonidae. Pp. 613-620 in YAnG, X.-K. (chief ed.). Chang Jiang San Xia ku qu kun chong [=Insects of the Three Gorge Reservoir area of Yangtze river]. Vol. 1. - Chongqing chu ban she [=Chongqing Publishing House], Chongqing, China. $\mathrm{xx}+974 \mathrm{pp}$.

YAnG, C.-K. 1999: Myrmeleonidae. Pp. 143-154, 165-167 in Huang, B.-k. (ed). Fujian kun chong zhi [=Fauna of Insects Fujian Province of China]. Vol. 3. Fujian ke xue ji shu chu ban she, Fuzhou [=Fujian Science and Technology Press, Fuzhou, China]. [ii] $+2+2+3+354+[$ ii] $p$ p

YANG, C.-K.; WANG, X.-L. 2002: Neuroptera: Myrmeleontidae. Pp. 296-299 in HuAnG, F.-s. (chief ed.). Hainan sen lin kun chong [=Forest insects of Hainan]. - Ke xue chu ban she [=Science Press], Beijing, China. [ix] $+\mathrm{XV}+1064 \mathrm{pp}$.

YANG, D.; LIU, X.-Y.; YANG, X.-K. (editorial committee chairs), et al. 2018: Species Catalogue of China. Vol. 2, Animals (II) [=Insecta (II)], Neuropterida. Science Press, Beijing. [x] + [x] +112 pp.

ZHAN, Q.-B.; ÁBrAHÁM, L.; WANG, X.-L. 2011: A new record species of Myrmeleon Linnaeus from China (Neuroptera, Myrmeleontidae). - Dong Wu Fen Lei Xue Bao; [=Acta Zootaxonomica Sinica] 36: $994-$ 996.

\section{websites}

http://www.africamuseum.be/collections/browsecollections/naturalsciences/biology/neuroptera/onespecies/ Macronemurus\%20tinctus/taxon - Accessed on 3rd March 2019.

LetARDI, A. Aspöck, H. \& AsPöck U. 2018: https://fauna-eu.org/ - Last accessed on 28. December 2018.

Mansell, M. W. 2018: The Antlions (Neuroptera: Myrmeleontidae) of South Africa https://www.ru.ac.za/ media/rhodesuniversity/resources/martin/myrmeleontidae.html. - Last accessed on 28. December 2018.

OswaLD, J. D. (chief editor) 2019: Lacewing Digital Library. Lacewing Digital Library module. http://lacewing.tamu.edu/. - Last accessed on 3rd December 2019. 